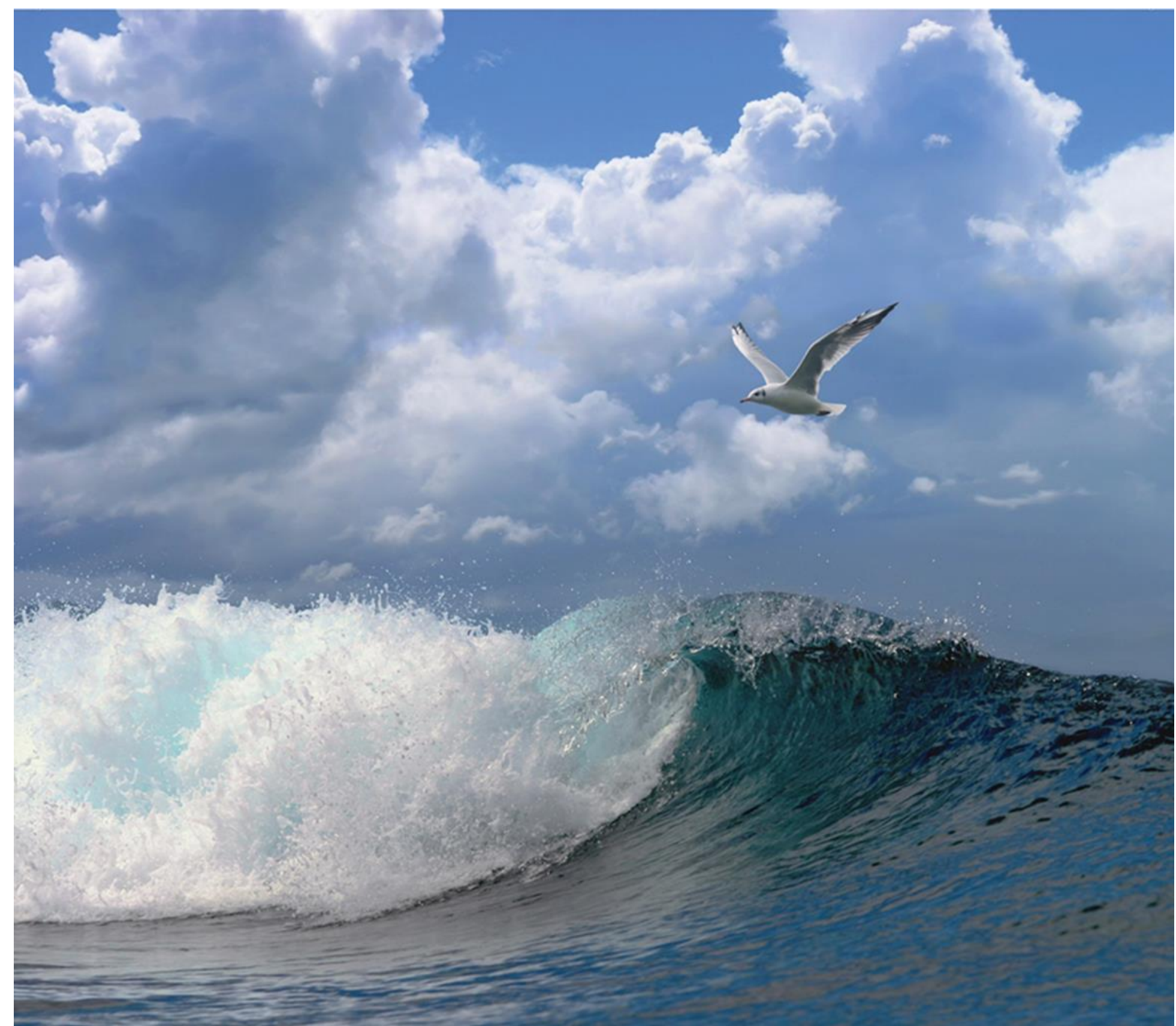

\title{
Validatie van het Zoute wateren EcotopenStelsel (ZES.1) in de Waddenzee
}




\section{Validatie van het Zoute wateren EcotopenStelsel (ZES.1) in de Waddenzee}

Auteurs: Susanne van Donk, Martin Baptist

Wageningen Marine Research 
Keywords: Bodemdieren, Ecotopen, Waddenzee.

Opdrachtgever: Rijkswaterstaat

T.a.v.: Rick Hoeksema (RWS-NN) \& Bas Kers (RWS-CIV)

Zuidersingel 3

8911 AV Leeuwarden

Dit rapport is gratis te downloaden van https://doi.org/10.18174/557468

Wageningen Marine Research verstrekt geen gedrukte exemplaren van rapporten.

Wageningen Marine Research is ISO 9001:2015 gecertificeerd.

\section{(c) Wageningen Marine Research}

Wageningen Marine Research, instituut binnen de rechtspersoon Stichting

Wageningen Research, hierbij vertegenwoordigd door Ir. M.T. van Manen, Directeur bedrijfsvoering

KvK nr. 09098104,

WMR BTW nr. NL 8113.83.696.B16.

Code BIC/SWIFT address: RABONL2U

IBAN code: NL 73 RABO 0373599285
Wageningen Marine Research aanvaardt geen aansprakelijkheid voor gevolgschade, noch voor schade welke voortvloeit uit toepassingen van de resultaten van werkzaamheden of andere gegevens verkregen van Wageningen 


\section{Inhoud}

$\begin{array}{ll}\text { Samenvatting } & 4\end{array}$

1.1 Ecotopenkaart van de Waddenzee 6

1.2 Doelstelling rapportage 6

1.2.1 Vraagstelling 6

1.2.2 Aanpak 1

3.1 Databronnen en dataselectie $\quad 11$

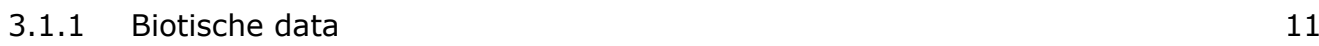

$\begin{array}{lll}3.1 .2 & \text { Abiotische data } & 15\end{array}$

3.1.3 Omgevingsvariabelen koppelen aan bemonsteringslocaties $\quad 15$

3.2 Karakteristieke soorten $\quad 15$

3.3 Bepalen grenswaarden 16

3.3.1 Habitat Mapping methode $\quad 16$

3.3.2 Testen grenswaarden m.b.v. lineaire regressiemodellen 17

3.3.3 Testen grenswaarden m.b.v. multivariate analyse (RDA) 17

$\begin{array}{lll}4.1 & \text { Karakteristieke soorten } & 19\end{array}$

$\begin{array}{lll}4.2 & \text { Grenswaarden } & 21\end{array}$

4.2.1 Droogvalduur 21

4.2.2 Stroomsnelheid en orbitaalsnelheid - zwakke versus sterke stroming en golven

4.2.3 Combinatie stroomsnelheid en orbitaalsnelheid - laagdynamisch versus hoogdynamisch

2.4 Sediment - Slibrijk fijn zand en grof zand

4.2.5 Zout - zoutgehalte en variatie

5.1 Conclusie en discussie $\quad 34$

$\begin{array}{lll}5.2 & \text { Aanbevelingen voor aanpassing ZES.1 } & 38\end{array}$

$\begin{array}{lll}5.3 & \text { Aanbevelingen voor vervolgonderzoek ZES.1 } & 39\end{array}$

$\begin{array}{ll}\text { Literatuur } & 41\end{array}$

Verantwoording
42

$\begin{array}{lll}\text { Bijlage } 1 \quad \text { Data exploratie } & 43\end{array}$

Abiotiek 43

Biotiek SIBES/Waddenmozaïek $\quad 43$

$\begin{array}{ll}\text { Biotiek WOT } & 47\end{array}$

$\begin{array}{ll}\text { Biotiek Amelander Zeegat } & 47\end{array}$

$\begin{array}{lll}\text { Bijlage } 2 & \text { Uitkomsten habitat mapping } & 48\end{array}$

$\begin{array}{lll}\text { Bijlage } 3 \quad \text { Testen grenswaarden } & 51\end{array}$

Bijlage $4 \quad$ Aanvullende analyses grenswaarden slibgehalte $\quad 54$ 


\section{Samenvatting}

Ecotopen zijn landschappelijke eenheden, gebaseerd op lokale fysische en biologische omgevingsfactoren. Deze omgevingsfactoren bepalen voor een groot deel de distributie van levensgemeenschappen van bodemdieren. Ecotopenkaarten kunnen daarom gebruikt worden om op een inzichtelijke manier te monitoren hoe het gaat met een natuurgebied als de Waddenzee. Voor de zoute wateren van Nederland is een methode beschreven om ecotopen te definiëren, het zogenoemde Zoute wateren EcotopenStelsel (ZES.1) opgesteld door Rijkswaterstaat.

Ecotopen worden onderscheiden van elkaar op basis van de belangrijkste fysische omgevingsfactoren en processen, zoals bijvoorbeeld droogvalduur en stroomsnelheid. Voor de toepassing van het ZES.1 in de Waddenzee zijn de grenswaarden voor deze omgevingsfactoren nog niet gevalideerd. Daarom zijn in deze rapportage analyses gepresenteerd die de klassegrenzen van het ZES. 1 valideren aan de hand van het voorkomen van bodemdieren. De vraag die hierbij werd gesteld was of de gebruikte grenzen ook relevant zijn voor de ecologie in de Waddenzee.

Voor de analyses is gebruikgemaakt van verschillende abiotische (omgevingsfactoren) en biotische (bodemdiergegevens) datasets. De abiotische gegevens (droogvalduur, stroomsnelheid, orbitaalsnelheid, saliniteit en sediment) zijn gekoppeld aan de biotische gegevens (dichtheid, biomassa, aantal soorten, ecologische rijkdom, diversiteit en soortsamenstelling) om analyses uit te kunnen voeren. Biotische gegevens kunnen op verschillende manieren verzameld worden. De soortsamenstelling of het type bodemdieren die voorkomen in de monsters kunnen verschillen door de manier en de plek van bemonsteren. Twee verschillende datasets die het litoraal en sublitoraal van de gehele Waddenzee beslaan zijn daarom gebruikt voor de analyses; SIBES/Waddenmozaïek en WOT. Voor de SIBES/Waddenmozaïek dataset ligt de focus op kleinere organismen en voor de WOT dataset op schelpdieren en grotere fauna. Daarnaast is ook een dataset gebruikt in de analyse van het sublitoraal in een buitendelta; het Amelander Zeegat. Alle biotische datasets komen uit 2019.

Voor het bepalen en valideren van grenswaarden is grotendeels een eerder gebruikte methode gevolgd; hierbij wordt de bodemdierdata (zoals bijvoorbeeld dichtheid aan bodemdieren) telkens in tweeën gesplitst op basis van een steeds verschuivende grenswaarde voor een abiotische factor (zoals bijvoorbeeld een grenswaarde voor stroomsnelheid van $78 \mathrm{~cm} / \mathrm{s}, 79 \mathrm{~cm} / \mathrm{s}, 80 \mathrm{~cm} / \mathrm{s}, 81 \mathrm{~cm} / \mathrm{s}, 82 \mathrm{~cm} / \mathrm{s}$ enz.). Vervolgens wordt getest welke splitsing in de data tot het beste resultaat leidt; bij welke grenswaarde zijn de ontstane groepen het meest verschillend van elkaar wat betreft bodemdiergegevens. In een tweede stap is met behulp van lineaire regressie en multivariate dataanalyse getest of een mogelijk nieuwe grenswaarde de biotische data beter verklaart dan voorheen.

Hieronder zijn de opvallendste resultaten kort weergegeven per onderzoeksvraag;

1. Een validatie van de droogvalduurklassen sublitoraal, laag, midden en hoog in relatie tot de distributie van bodemdieren.

Uit de bodemdiergegevens blijkt dat klassegrens tussen litoraal-midden en litoraal-hoog beter gelegd kan worden op $40 \%$ droogvalduur in plaats van $75 \%$ droogvalduur.

2. Een validatie van de $0,8 \mathrm{~m} / \mathrm{s}$ stroomsnelheidsgrens in relatie tot de sublitorale distributie van bodemdieren.

Analyses van de verschillende bodemdierdatasets suggereerden iets verschillende grenswaarden per dataset om zwakke van sterke stroming te onderscheiden, te weten bij 0,8 $\mathrm{m} / \mathrm{s}$ (WOT; dezelfde waarde als in het ZES.1), 0,9 m/s (data Amelander Zeegat) en 1,0 m/s (SIBES/Waddenmozaïek). De aanbeveling is om ZES.1 ongewijzigd te laten.

3. Een validatie van de combinatie van de grenzen uit stromingsdynamiek en golfdynamiek in relatie tot sublitorale bodemdieren.

Voor het onderscheid tussen zwakke en sterke golven zijn grenswaarden verschillend per dataset; te weten geen duidelijke grenswaarde (SIBES/Waddenmozaïek), een grenswaarde van 0,25 m/s (WOT; dezelfde waarde als in het ZES.1) en een grenswaarde van 0,5 m/s in de 
buitenwateren van het Amelander Zeegat. De gecombineerde analyse van stroom- en orbitaalsnelheid samen toont vergelijkbare waardes, alhoewel nu bij elke dataset de waarde van $0,5 \mathrm{~m} / \mathrm{s}$ voor orbitaalsnelheid naar voren komt.

4. Een validatie van de zoutgehalte- en zoutvariatiecategorieën (brak versus zout en variabel versus niet-variabel) in relatie tot de distributie van bodemdieren

Er zijn geen duidelijke grenswaarden gevonden voor zoutgehalte en -variatie.

5. Een validatie van de sedimentcategorieën (slibrijk, fijn zand en grof zand) in relatie tot de distributie van bodemdieren

De analyse van de bodemdiergegevens van zowel SIBES-Waddenmozaïek en WOT suggereren beiden een lagere grenswaarde om slibrijk van slibarm te onderscheiden; van een grenswaarde van $25 \%$ uit het ZES. 1 systeem naar een grenswaarde van $3 \%$ (SIBESWaddenmozaïek) of $10-20 \%$ (WOT).

Uit de resultaten zijn de volgende aanbevelingen geformuleerd door het meenemen van zowel de uitkomsten van de hierboven beschreven en bediscussieerde resultaten en het praktisch gebruik van het ecotopenstelsel;

- $\quad$ Een nieuwe grenswaarde tussen litoraal-midden en litoraal-hoog van 40\% i.p.v. 75\% droogvalduur en behoud van andere grenswaarden voor droogvalduur ( $4 \%, 25 \%$ en $85 \%)$.

- Handhaven van de grenswaarde van 0,8 m/s voor stroomsnelheid om zwakke van sterke stroming te onderscheiden in het sublitoraal.

- Een extra dynamiekklasse invoeren voor de orbitaalsnelheid in het sublitoraal leidend tot twee grenswaarden van $0,25 \mathrm{~m} / \mathrm{s}$ en $0,5 \mathrm{~m} / \mathrm{s}$. De combinatie van stroomsnelheid en orbitaalsnelheid leidt tot drie klassen: laag-dynamisch (orbitaalsnelheid $<0,25 \mathrm{~m} / \mathrm{s}$ en stroomsnelheid $<0,8 \mathrm{~m} / \mathrm{s}$ ), middel-dynamisch (orbitaalsnelheid tussen 0,25-0,5 $\mathrm{m} / \mathrm{s}$ en stroomsnelheid $<0,8 \mathrm{~m} / \mathrm{s}$ ) en hoog-dynamisch (orbitaalsnelheid $>0,5 \mathrm{~m} / \mathrm{s}$ of stroomsnelheid $>0,8 \mathrm{~m} / \mathrm{s}$ ).

- Drie sedimentklassen onderscheiden op basis van slibgehalte in het bodemsediment die worden beschreven als slibarm grof zand ( $<3 \%$ slib \& $>250 \mu \mathrm{m} \mathrm{D50}$ ), slibhoudend fijn zand (3\%-15\% slib \& 125-250 $\mu \mathrm{m}$ D50) en slibrijk zeer fijn zand ( $>15 \%$ slib \& $<125 \mu \mathrm{m}$ D50).

- $\quad$ Voorlopig behoud van grenswaarden voor zoutgehalte en zoutvariatie. 


\section{$1 \quad$ Inleiding}

\section{$1.1 \quad$ Ecotopenkart van de Waddenzee}

Ecotopen zijn landschappelijke eenheden, gebaseerd op lokale fysische en biologische omgevingsfactoren (Bouma et al., 2005). De ruimtelijke variatie hiervan bepaalt voor een groot deel de distributie van levensgemeenschappen zoals die van bodemdieren maar ook vogels en vissen die bodemdieren eten. De aanname is dat door het in kaart brengen van ecotopen over de tijd de leefgebieden van bodemdieren, vissen en vogels worden aangegeven en zo situaties in verleden en heden met elkaar vergeleken kunnen worden. Door middel van ecotopenkaarten kan op een inzichtelijke manier gemonitord en getoond worden hoe het gaat met een natuurgebied als de Waddenzee (M J Baptist et al., 2016).

Medio 2020 is een zoute ecotopenkaart Waddenzee 2017 opgeleverd door Rijkswaterstaat-CIV (Paree et al., 2020). De ecotopen zijn beschreven door een hiërarchisch opgebouwd Zoute wateren EcotopenStelsel (ZES.1). De ecotopenkaart 2017 (Figuur 1) is de start van een nieuwe monitoringscyclus waarin het jaarlijks een update krijgt. Dit houdt in dat er per jaar per kombergingsgebied een kaart gemaakt wordt, zodat in zes jaar tijd de gehele Waddenzee gekarteerd wordt. De kartering wordt gebaseerd op de meetprogramma's van de hoogte- en dieptemetingen (vaklodingen) en er worden luchtfoto's voor gevlogen. Tevens zal de benodigde hydrodynamische modellering verder ontwikkeld worden t.b.v. meer detail en betrouwbaarheid (Van Weerdenburg \& Vroom, 2021).

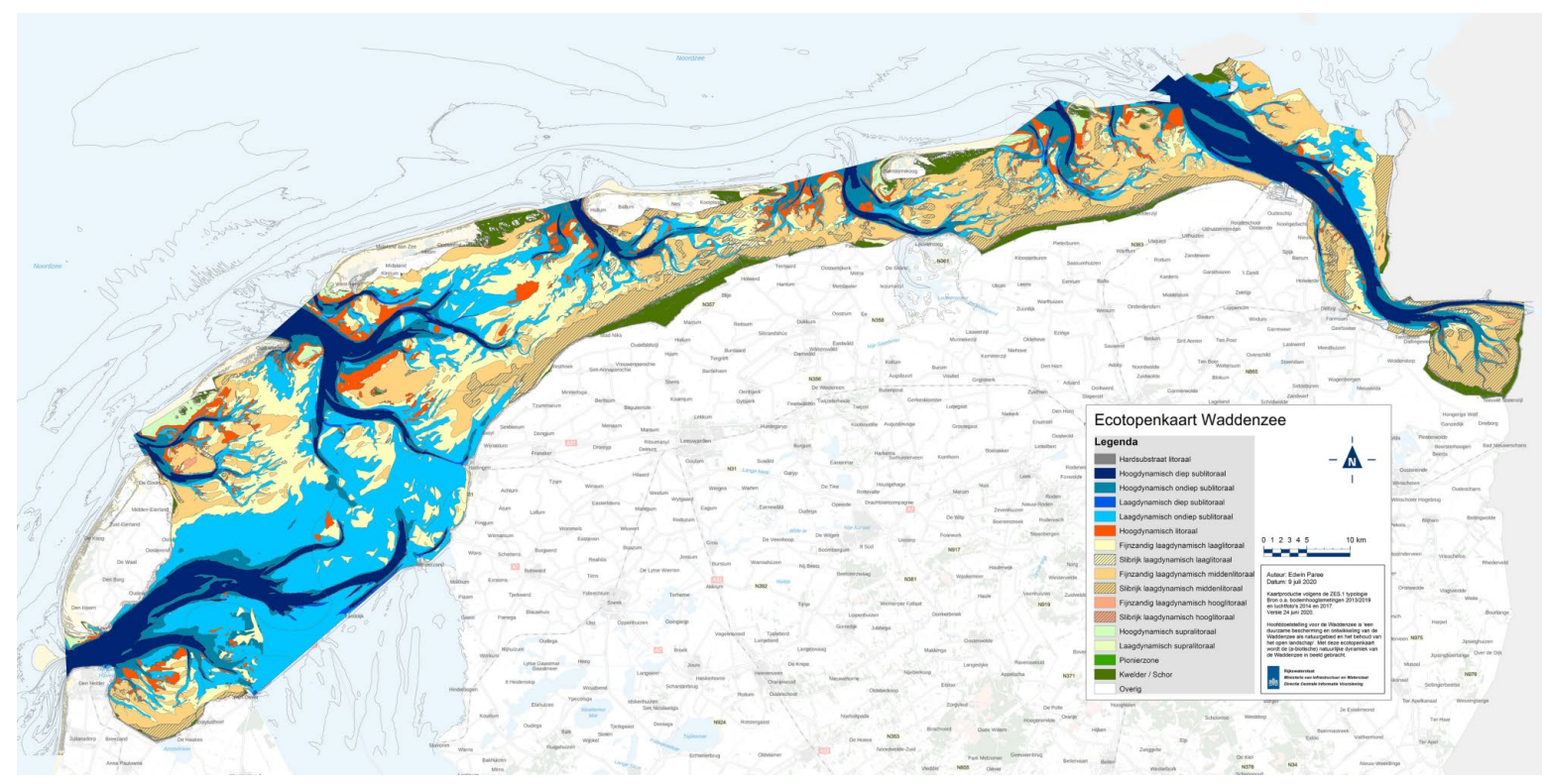

Figuur 1

Ecotopenkaart Waddenzee 2017 (Paree et al., 2020).

\subsection{Doelstelling rapportage}

\subsubsection{Vraagstelling}

Ecotopen worden van elkaar onderscheiden op basis van de belangrijkste fysische omgevingsfactoren en processen. In het ZES.1 zijn hiervoor een aantal abiotische indelingskenmerken gekozen. Zo wordt bijvoorbeeld voor het onderscheiden van laag- en hoogdynamische ecotopen in het sublitorale deel van de Waddenzee een grenswaarde van de abiotische variabele stroomsnelheid van 0,8 m/s gebruikt. Deze indelingskenmerken zijn voor de belangrijkste omgevingsfactoren gevalideerd in de 
Westerschelde. Hieruit kwamen grenswaarden die meestal redelijk in de buurt liggen bij de waarden zoals die momenteel in het ZES.1 staan (Van Wesenbeeck et al., 2010). Voor de Waddenzee is een dergelijke validatie nog niet uitgevoerd. Bovendien is bij de vervaardiging van de ecotopenkaart Waddenzee ook voor het eerst orbitaalsnelheid van golven meegenomen voor de indeling van hoogdynamische sublitorale ecotopen.

In deze rapportage zijn de klassegrenzen van het Zoute wateren EcotopenStelsel zoals toegepast op de zoute ecotopenkaart Waddenzee 2017 gevalideerd aan de hand van bodemdiergegevens;

1. Een validatie van de droogvalduurklassen in relatie tot de litorale distributie van bodemdieren (laag, midden en hoog).

2. Een validatie van de $0,8 \mathrm{~m} / \mathrm{s}$ stroomsnelheidsgrens in relatie tot de sublitorale distributie van bodemdieren.

3. Een validatie van de combinatie van de grenzen uit stromingsdynamiek en golfdynamiek in relatie tot sublitorale bodemdieren.

4. Een validatie van de zoutgehalte- en zoutvariatiecategorieën (brak versus zout en variabel versus niet-variabel) in relatie tot de distributie van bodemdieren.

5. Een validatie van de sedimentcategorieën (slibrijk, fijn zand en grof zand) in relatie tot de distributie van bodemdieren.

6. Aanvullend is een overzicht gemaakt van karakteristieke bodemfauna per ecotoop.

\subsubsection{Droogvalduur}

In het ZES.1 wordt onderscheid gemaakt tussen de litorale zone en de sublitorale zone. Toepassing van het ecotopenstelsel in de Westerschelde maakte duidelijk dat de grens tussen sublitoraal en litoraal het beste gelegd kon worden bij een droogvalduur van 4\% (Kers et al., 2013). De grens van $4 \%$ tussen sublitoraal en litoraal wordt in deze rapportage gevalideerd voor de Waddenzee. Tevens worden de grenswaarden die gebruikt zijn voor de verschillende litorale klassen gevalideerd. Deze zijn in het ZES. 1 gedefinieerd op basis van onder andere BIOMON biomassagegevens van de Westerschelde (Bouma et al., 2005). Dit zijn litoraal-laag met een droogval tussen 4-25\%, litoraalmidden met een droogval tussen $25-75 \%$ en litoraal-hoog met een droogval tussen $75-85 \%$.

\subsubsection{Stroomsnelheid}

In het ZES. 1 wordt onderscheid gemaakt tussen laagdynamische en hoogdynamische ecotopen. Deze ecotopen zijn vaak duidelijk van elkaar te onderscheiden door aanwezigheid van grote ribbels (tot 1 à 2 meter hoog) in de hoogdynamische ecotopen die gevormd worden door sterke stroming van minimaal 0,8 m/s (Boothroyd \& Hubbard, 1975; Bouma et al., 2005). De grens van 0,8 m/s voor het onderscheid tussen laag- en hoogdynamisch in het sublitoraal wordt in deze rapportage gevalideerd voor de sublitorale delen in de Waddenzee. Hiervoor wordt het $99^{e}$ percentiel voor stroomsnelheid gebruikt. Deze grens is enkel relevant voor sublitorale ecotopen, omdat in het litoraal hoogdynamische bodemvormen in kaart worden gebracht met behulp van luchtfoto's en Object Based Image Analysis (Paree et al., 2020).

\subsubsection{Orbitaalsnelheid en combinatie stroomsnelheid \& orbitaalsnelheid}

Naast stroomsnelheid hebben ook golven invloed op de bodemstructuur (Bouma et al., 2005). Golven kunnen een sterker effect hebben dan lineaire stroomsnelheid, omdat golven geen constante maar een meer 'plukkend' effect hebben op de bodem. De grens tussen laag- en hoogdynamisch ligt voor orbitaalsnelheid daarom lager dan bij stroomsnelheid (Bouma et al. 2009). De grens voor de ecotopenkaart Waddenzee 2017 werd gelegd op 0,25 m/s in plaats van 0,2 m/s op basis van expertkennis (de grens van 0,2 m/s leverde hoogdynamische ecotopen op, op plekken waar deze niet horen). In het ZES. 1 wordt een combinatie van stroomsnelheid en orbitaalsnelheid gebruikt met in de Waddenzee de volgende klassen:

- Hoogdynamisch: stroomsnelheid $>0,8 \mathrm{~m} / \mathrm{s}$ en/of orbitaalsnelheid $>0,25 \mathrm{~m} / \mathrm{s}$.

- Laagdynamisch: stroomsnelheid $<0,8 \mathrm{~m} / \mathrm{s}$ en orbitaalsnelheid $<0,25 \mathrm{~m} / \mathrm{s}$.

De grens van $0,25 \mathrm{~m} / \mathrm{s}$ voor het onderscheid tussen laag- en hoogdynamisch in het sublitoraal wordt in deze rapportage gevalideerd voor de sublitorale delen in de Waddenzee. In het litoraal wordt de grens tussen laag- en hoogdynamisch gemaakt op basis van luchtfoto's.

Tevens wordt in deze rapportage gekeken naar klassegrenzen van een combinatie van stroomsnelheid en orbitale snelheid. 


\subsubsection{Zoutgehalte}

Saliniteit wordt in ZES.1 gezien als meest sturend op de soortensamenstelling van bodemdieren. De saliniteit is in twee variabelen onderscheiden, het zoutgehalte en de zoutvariatie (Bouma et al., 2005).

Het zoutgehalte is in ZES.1 gedefinieerd als het gemiddelde zoutgehalte bij hoog water over een jaar met een gemiddelde zoetwaterafvoer. Voor de klassegrenzen voor het zoutgehalte is in ZES. 1 gebruik gemaakt van het Venetië-systeem voor de indeling van brakke wateren. De volgende klassen worden onderscheiden:

- Brak: water met een gemiddeld zoutgehalte tussen 5,4 en 18 (3-10 g Cl-/I)

- Zout: water met een gemiddeld zoutgehalte $>18(10 \mathrm{~g} \mathrm{Cl}-/ \mathrm{l})$

Het ZES. 1 omvat geen klasse voor zoutgehalte van 0,5-5,4 (0,3-3 g Cl-/l) terwijl dit zoutgehalte wel voorkomt in de Waddenzee. In de trilaterale ecotopenkaart van de Waddenzee (Baptist et al., 2019) is er daarom voor gekozen om de klasse brak te definiëren tussen 0,5-18.

De zoutvariatie is in ZES.1 gedefinieerd bij hoogwater als [( 4 x standaarddeviatie zoutgehalte) / gemiddelde zoutgehalte] x 100\%. In het ZES. 1 wordt onderscheid gemaakt tussen weinig variabele zoutvariatie van $\leq 100 \%$ en variabel een zoutvariatie van $>100 \%$ (Bouma et al., 2005; Vos \& Wolff, 2001). Deze grens werd niet gebaseerd op basis van bodemdiergegevens.

De grenzen voor zoutgehalte en variatie worden in deze studie gevalideerd door middel van bodemdiergegevens in de Waddenzee voor litoraal en sublitoraal.

\subsubsection{Sediment}

Sedimentsamenstelling beïnvloedt het voorkomen van bodemdieren. In het ZES.1 is voor een indeling in sedimentsamenstelling gekozen voor de variabelen slibgehalte en mediane korrelgrootte waarbij de klasseindeling is gebaseerd op het voorkomen van bodemdieren in de Westerschelde (Bouma et al., 2005). De volgende klassen worden onderscheiden:

- $\quad$ slibrijk (slibgehalte $\geq 25 \%$ ongeacht de mediane korrelgrootte),

- $\quad$ fijn zand (mediane korrelgrootte $\leq 250 \mu \mathrm{m}$ en slibgehalte $<25 \%$ ),

- $\quad$ grof zand (mediane korrelgrootte 250-2000 $\mu \mathrm{m}$ en slibgehalte $<25 \%$ )

- $\quad$ grind (mediane korrelgrootte $>2000 \mu \mathrm{m}$ ).

De Waddenzee bestaat vooral uit slibrijk en fijn zand. De grenzen voor slibrijk en slibarm sediment en voor fijn en grof zand worden in deze studie gevalideerd in de Waddenzee voor het litoraal en sublitoraal aan de hand van de distributie van bodemdieren. De aanwezigheid van schelpdierbanken en de invloed hiervan op sedimenteigenschappen wordt niet apart meegenomen omdat deze in het ZES. 1 als eco-elementen worden beschouwd (en dus als kleinere gebieden waarin zich karakteristieke levensgemeenschappen met structurerende eigenschappen bevinden, die afwijken van de levensgemeenschappen die worden aangetroffen elders in het betreffende ecotoop).

\subsubsection{Aanpak}

Grenswaarden worden getest door abiotische indicatoren (droogvalduur, stroomsnelheid, orbitaalsnelheid, saliniteit en sediment) te koppelen aan bodemdiergegevens. Bodemdieren kunnen op verschillende manieren verzameld worden. Door de manier en de plek van bemonsteren kan de soortsamenstelling of het type bodemdieren die voorkomen in de monsters verschillen. Er is gekozen voor uitvoeren van de analyse op drie verschillende datasets die in hetzelfde jaar zijn verzameld, namelijk het jaar 2019, te weten SIBES/Waddenmozaïek, WOT schelpdieren Waddenzee/Noordzee, en Kustgenese 2.0 Amelander Zeegat. De gekozen datasets hebben een grote ruimtelijke dekking en bevatten recente gegevens over bodemdieren. Datasets die zijn overwogen maar zijn afgevallen zijn: - Bodemfauna litorale delen Balgzand - NIOZ (onvoldoende ruimtelijke dekking);

- Bodemfauna Waddenzee MWTL - RWS (onvoldoende ruimtelijke dekking);

- Sublitoraal benthos Westelijke Waddenzee 2008 - NIOZ/WMR/MarinX (geen recente data waardoor bijvoorbeeld Amerikaanse zwaardschedes grotendeels ontbreken).

$\mathrm{Er}$ is gekozen voor het jaar 2019 omdat alleen voor dit jaar voor alle drie de geselecteerde datasets bodemdiergegevens beschikbaar zijn, terwijl de abiotische modelgegevens waarmee de ruimtelijke 
distributie van bodemdieren wordt beschreven uit 2017 en 2020 komen. Hoewel de dichtheid en biomassa grote verschillen tussen jaren kennen is de ruimtelijke verspreiding van bodemdiergemeenschappen in de Waddenzee tamelijk constant tussen jaren, wat maakt dat de verspreiding van levensgemeenschappen tamelijk ongevoelig is voor veranderingen in milieuomstandigheden op de korte termijn (Folmer et al., 2017). Bovendien steunen de modelgegevens voor de ecotopenkaart op basisdata voor bodemhoogte die afkomstig is van vaklodingen uit verschillende jaren, namelijk 2013-2019. Het is daarom onwaarschijnlijk dat de keuze voor bodemdiergegevens uit het jaar 2019 een wezenlijk andere uitkomst geeft dan een keuze voor bijvoorbeeld het jaar 2017. Dit zou in een vervolgonderzoek getoetst kunnen worden.

De statistische analyse bestaat uit een data exploratie, waarbij gekeken is welke abiotische indicatoren een rol spelen in de verklaring van variatie in de bodemdiergegevens. Vervolgens is grotendeels een eerdere methode gevolgd (Van Wesenbeeck et al., 2010; Ysebaert et al., 2016). Deze methode bestaat uit een zogenoemde "Habitat Mapping"; hierbij wordt de bodemdierdata telkens in tweeën gesplitst op basis van een abiotische factor voor steeds verschuivende grenswaarden (zoals bijvoorbeeld een klassegrens voor een droogvalduurklasse van 38\%, 39\%, 40\%, 41\%, 42\% enz.). Vervolgens wordt getest welke splitsing in de data tot het beste resultaat leidt; bij welke grenswaarde zijn de ontstane groepen het meest verschillend van elkaar wat betreft bodemdiergemeenschappen. Wanneer deze analyse een mogelijk andere grenswaarde aangeeft voor een abiotische factor dan de grenswaarde uit het ZES.1, worden de oude en nieuwe grenswaarden beiden getest door lineaire modellen met elkaar te vergelijken met als responsvariabele de abiotische factor. Daarnaast zijn de grenzen ook getest met behulp van soortsamenstelling door middel van multivariate data-analyse. Op basis van deze uitkomsten worden aanbevelingen gedaan wat betreft het aanpassen van grenswaarden voor het ZES.1. De oude grenswaarden worden zoveel mogelijk gehandhaafd omdat veel veranderingen in het systeem verwarring kan opleveren. Een aanbeveling kan daarom zijn om een bestaande grenswaarde te behouden, ook als er in de analyse een nieuwe grenswaarde is gevonden. Dit kan bijvoorbeeld zijn wanneer de nieuwe grenswaarde dichtbij de gebruikte grenswaarde ligt. 


\section{Kennisvraag}

Deze rapportage toont de validatie van de klassegrenzen in het Zoute wateren EcotopenStelsel zoals toegepast op de zoute ecotopenkaart Waddenzee 2017. Hiermee zullen de bestaande klassegrenzen getoetst worden aan de hand van bodemdiergegevens en zal, als dat uit de analyse blijkt, advies gegeven worden over het veranderen van klassegrenzen. Hiermee zal het Zoute wateren EcotopenStelsel een betere representatie geven van de ecologie van de Waddenzee.

De focus van de analyse ligt op vijf validaties:

1. Een validatie van de droogvalduurklassen in relatie tot de distributie van bodemdieren (sublitoraal, laag, midden en hoog).

2. Een validatie van de $0,8 \mathrm{~m} / \mathrm{s}$ stroomsnelheidsgrens in relatie tot de sublitorale distributie van bodemdieren.

3. Een validatie van de combinatie van de grenzen uit stromingsdynamiek en golfdynamiek (orbitaalsnelheid) in relatie tot sublitorale bodemdieren.

4. Een validatie van de klassegrenzen voor zoutgehalte en zoutvariatie.

5. Een validatie van de klassegrenzen voor sedimentsamenstelling. 


\section{Methoden}

\subsection{Databronnen en dataselectie}

\subsubsection{Biotische data}

\subsubsection{Synoptic Intertidal Benthic Surveys Wadden Sea (SIBES) \& Waddenmozaïek}

Het SIBES programma van het Koninklijk Nederlands Instituut der Zee (NIOZ) bemonstert bodemdieren van droogvallende delen in de Waddenzee in een regelmatig grid van $500 \times 500$ m met $10 \%$ random locaties (Figuur 2). Locaties worden te voet of per boot bezocht. Op locaties die bezocht worden per voet, wordt per station één steekbuismonster genomen met een oppervlakte van 0,0177 $\mathrm{m}^{2}$ tot een diepte van $25 \mathrm{~cm}$. Op locaties die bezocht worden per boot worden per station twee steekbuismonsters genomen met een gezamenlijk oppervlakte van 0,0173 $\mathrm{m}^{2}$ tot een diepte van 25 $\mathrm{cm}$. Monsters worden gezeefd over een $1 \mathrm{~mm}$ zeef. Grote schelpdieren worden apart genomen en ingevroren, de rest van het monster wordt bewaard in een $4 \%$ formaline oplossing. Ook sediment wordt bemonsterd op een regelmatig grid van $500 \times 500 \mathrm{~m}$. Met een sediment steekbuisje wordt per locatie één monster genomen tot een diepte van $4 \mathrm{~cm}$. Het aantal bezochte stations ligt rond de 4500 . Sinds 2015 heeft het NIOZ ook het (merendeels) sublitoraal van de Waddenzee bemonsterd als onderdeel van de SIBES campagnes, gebruikmakend van dezelfde methoden maar in een grid met een onderlinge afstand van $1000 \times 1000 \mathrm{~m}$ (Figuur 2). Dit heeft ongeveer 1500 monsterpunten opgeleverd. Sinds 2019 is een systematische monitoring in het sublitorale deel van de Waddenzee onderdeel van het Waddenfonds Waddenmozaïek project. In de analyse zijn 5538 monsterpunten gebruikt waarvan 1326 van het Waddenmozaïekproject.

Data van SIBES en Waddenmozaïek is opgevraagd bij het NIOZ voor het jaar 2019. Dit is het enige jaar waarvoor alle bodemdiergegevens zijn uitgewerkt en beschikbaar voor analyse. Er is toestemming verleend om de data te gebruiken voor het specifieke doeleinde van deze rapportage. SIBES en Waddenmozaïek datasets zijn voor deze analyse samengevoegd omdat ze op dezelfde manier bemonsterd zijn. De dataset bestaat uit de dichtheid (aantal individuen per $\mathrm{m}^{2}$ ) en biomassa (asvrij drooggewicht per $\mathrm{m}^{2}$ ) per gevonden soort of soortgroep.

De wijze van bemonsteren in SIBES en Waddenmozaïek (een relatief klein oppervlakte met een fijne zeef), is minder geschikt voor het meten van grotere mobiele soorten, omdat deze makkelijk buiten de steekbuis kunnen blijven. Daarom zijn de grotere mobiele soorten als de grijze garnaal Crangon crangon, de strandkrab Carcinus maenas, de gewone zeester Asterias rubens, en krabben van het geslacht Hemigrapsus niet meegenomen in verdere analyse met deze datasets.

De datasets zijn gescand op extreme waardes. Één datapunt van de Waddenmozaïek dataset is verwijderd voor verdere analyse (dichtheid groter dan 1000000). In de SIBES en Waddenmozaïek dataset komen negatieve as-vrij-drooggewichtwaardes voor. Deze waardes kunnen ontstaan door de afwijking van de weegschaal en een zeer laag gemeten gewicht (pers. comm. NIOZ). Deze waardes zijn voor individuele soorten veranderd naar nul. Voor het berekenen van het totale gewicht per positie, zijn deze negatieve waardes echter wel meegenomen, omdat op deze manier ook enigszins gecorrigeerd wordt voor de afwijking van de weegschaal. Dit leverde geen negatieve waardes op voor meetpunten. 


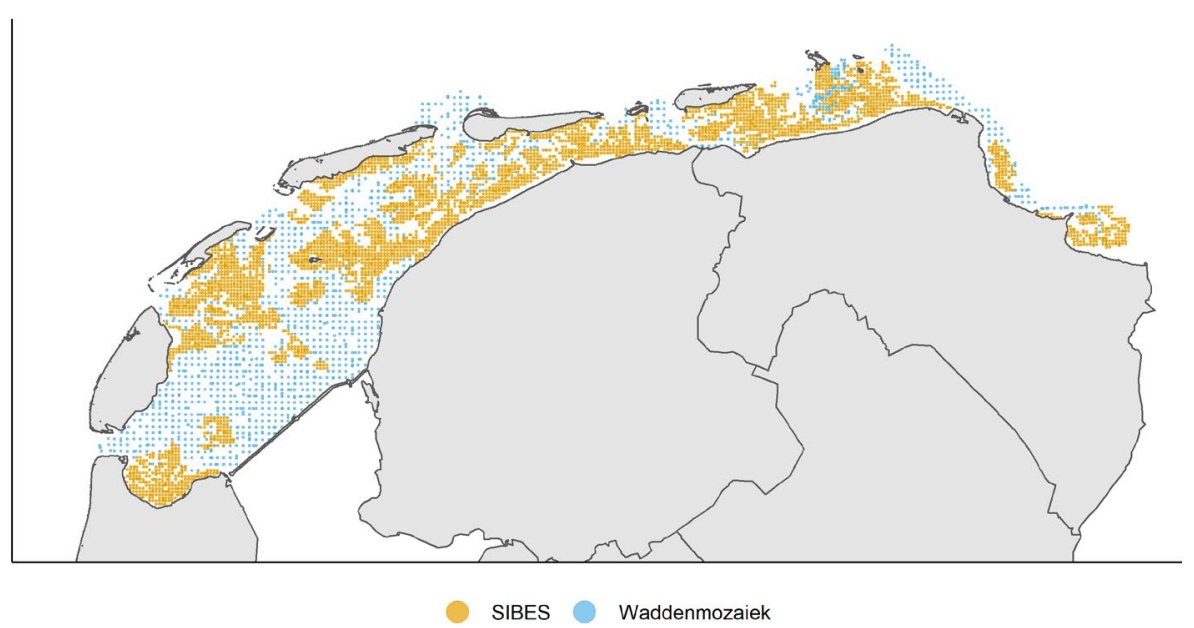

Figur 2 Ruimtelijk beeld van meetpunten van het SIBES en Waddenmozaïekprogramma.

\subsubsection{Wettelijke Onderzoekstaken (WOT) litorale en ondiep sublitorale schelpdierbestanden Waddenzee \& schelpdieren Noordzeekustzone}

Het WOT-programma uitgevoerd door WMR bemonstert schelpdiervoorkomen (en andere bodemfauna) in het litoraal en het ondiepe sublitoraal van de Waddenzee in het voorjaar, met de focus op commercieel interessante soorten zoals kokkels en mosselen (Figuur 3). Het gebied wordt verdeeld in verschillende strata (gebieden met een verschillende kans in voorkomen van schelpdieren). Voor een overzicht van de strata wordt verwezen naar Tabel 2 in Troost et al.(2021) Over die strata ligt een grid waarover de monsterpunten zijn verdeeld. Monstername vindt plaats op verschillende manieren; vanaf een schip met een stempelkor met een oppervlakte van 2 bij 0,21 meter $\left(0,42 \mathrm{~m}^{2}\right)$, vanaf een bijboot met een kokkelschepje ( 3 monsters per locatie, met een totaal oppervlak van $0.1 \mathrm{~m}^{2}$ ), te voet met een steekbuis met diameter $25 \mathrm{~cm}$ (per locatie 2 monsters met een totaal oppervlak van $0.1 \mathrm{~m}^{2}$ ) en in dichte oesterbanken met een hydraulische bodemhapper (oppervlak 1,0 $\mathrm{m}^{2}$ ). Monsters worden gezeefd over een $5 \mathrm{~mm}$ zeef. Het aantal bezochte stations ligt rond de 1500 .

Het WOT-programma doet ook een specifieke bestandsopname voor schelpdieren (en andere bodemfauna) 1 keer per jaar op \pm 600 locaties in de Noordzeekustzone en 250 locaties in de Voordelta. Monstername vindt plaats met een bodemschaaf (locaties dieper dan 10 meter), Van Veen bodemhapper (gebied van de Texelse stenen) of zuigkor (Voordelta, ondieper dan 10 meter). Gegevens van het WOT-programma zijn bij WMR en staan in Informatiehuis Marien en kunnen zonder toestemming gebruikt worden. Voor deze analyse zijn ter vergelijking van de NIOZ data de bodemdiergegevens van 2019 gebruikt. De dataset bestaat uit de dichtheid (aantal individuen per $\mathrm{m}^{2}$ ) en biomassa (asvrij drooggewicht per $\mathrm{m}^{2}$ ) per gevonden soort of soortgroep. Vanwege de vele gebruikte bemonsteringsoppervlaktes in het WOT-programma, en de correlatie tussen bemonsterd oppervlakte en aantal gevonden soorten in een monster ligt de focus bij de analyse van deze dataset op dichtheid en biomassa per $\mathrm{m}^{2}$.

Het WOT-bemonsteringsprogramma heeft zowel bemonsteringspunten in de Waddenzee als in de Noordzee (Figuur 3). Voor de meeste analyses zijn enkel de Waddenzee-datapunten gebruikt, maar voor stroomsnelheid en orbitaalsnelheid zijn ook de Noordzee-datapunten apart geanalyseerd. Omdat in de Noordzee de buitendelta's grotendeels niet bemonsterd worden vanwege de verraderlijke ondieptes is een aparte dataset voor het Amelander Zeegat meegenomen in de analyse, zie onderstaand. 


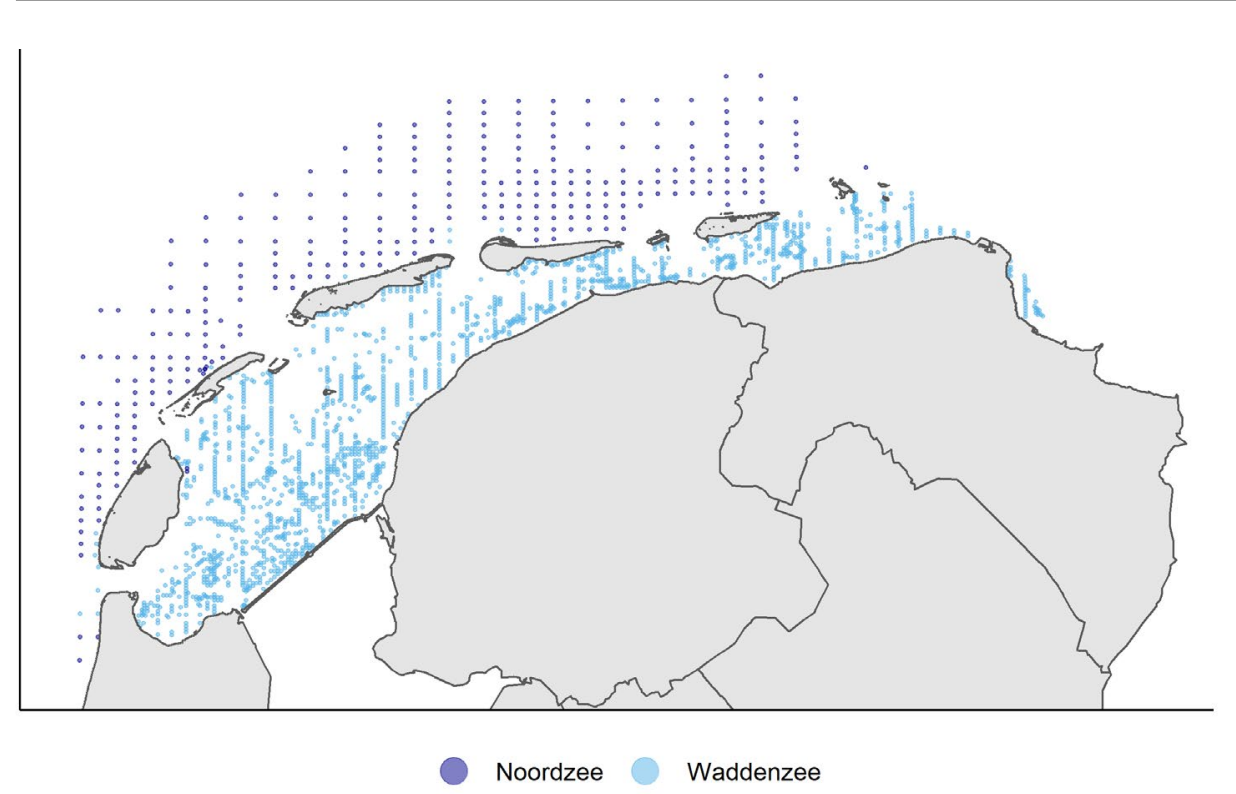

Figuur $3 \quad$ Ruimtelijk beeld van meetpunten van WOT-programma.

\subsubsection{Amelander Zeegat}

Binnen het onderzoeksprogramma Kustgenese 2.0 is de infauna bemonsterd van het Amelander Zeegat door Rijkswaterstaat. Monsters zijn genomen met een boxcore $\left(0,078 \mathrm{~m}^{2}\right)$ in september 2017, maart 2018 en september 2019. Er zijn in totaal ongeveer 200 monsters genomen en gedetermineerd door Eurofins (bv.) (Schellekens \& Verduin, 2020; Verduin \& Leewis, 2017). Monsters werden gezeefd over een 0,5 $\mathrm{mm}$ zeef. De dataset bestaat uit de dichtheid (aantal individuen per $\mathrm{m}^{2}$ ) en biomassa (asvrij drooggewicht per $\mathrm{m}^{2}$ ) per gevonden soort of soortgroep. Voor deze analyse zijn de monsters uit 2019 gebruikt.

De wijze van bemonsteren (een relatief klein oppervlakte met een fijne zeef), is minder geschikt voor het meten van grotere mobiele soorten, omdat deze makkelijk buiten de steekbuis kunnen blijven. Daarom zijn de grotere mobiele soorten als de grijze garnaal Crangon crangon, de strandkrab Carcinus maenas, de gewone zeester Asterias rubens, en krabben van het geslacht Hemigrapsus niet meegenomen in verdere analyse met deze datasets. N.B. in het Amelander Zeegat is gevist op zandspiering-achtigen. Dit is niet meegenomen in deze analyse.

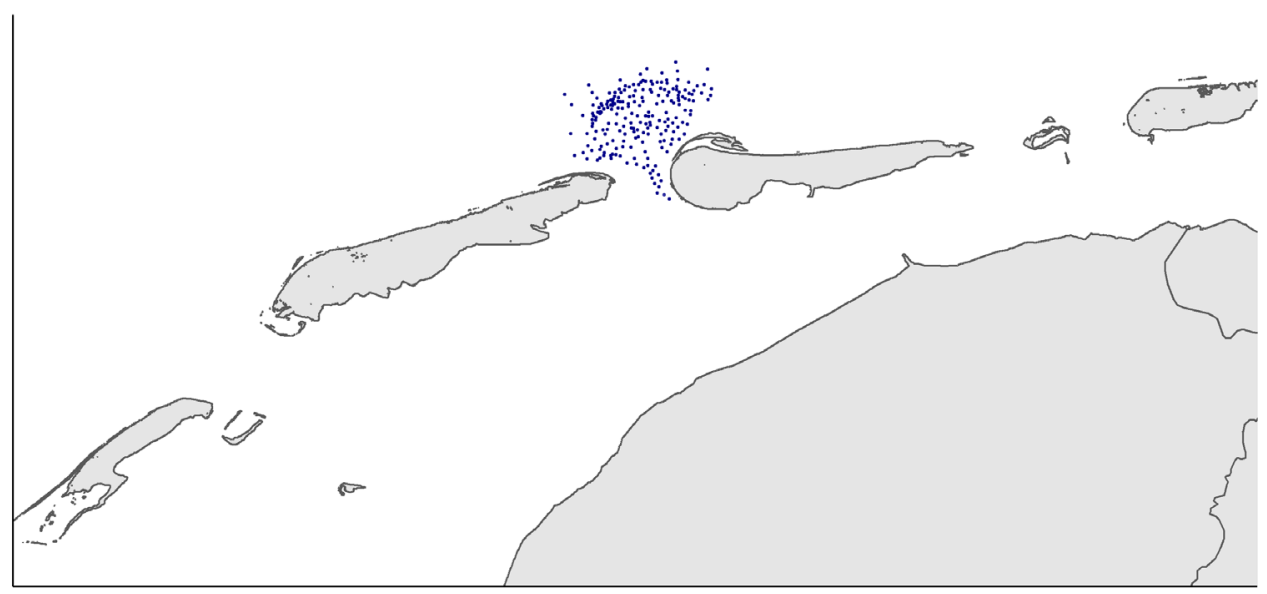

Figuur 4 Ruimtelijk beeld van meetpunten in het Amelander Zeegat.

\subsubsection{Biotische indicatoren}

Voor analyse zijn een aantal biologische indicatoren bepaald uit de bodemdiergegevens die later zijn gekoppeld aan de abiotische data. De biotische indicatoren zijn (1) Soortenrijkdom, (2) Dichtheid, (3) Biomassa, (4) Ecologische rijkdom en (5) Diversiteit.

(1) Soortenrijkdom is berekend als het aantal unieke soorten of soortgroepen gevonden per monster. Het aantal soorten dat gevonden wordt per monster is afhankelijk van het 
bemonsterde oppervlakte; hoe groter het bemonsterde oppervlakte hoe meer soorten je aantreft. Daarom is deze maat relatief en niet absoluut. Voor de WOT data zijn verschillende oppervlaktes bemonsterd, afhankelijk van habitat en diepte. Daarnaast worden bij bemonsteringen met de schaaf of zuigkor ook vaak subsamples genomen aan boord waardoor zeldzame soorten makkelijker over het hoofd worden gezien. Het aantal soorten per positie is daarom mogelijk niet betrouwbaar voor deze dataset. In de analyse is voor de WOT data meer gefocust op de resultaten uit dichtheid en biomassa.

(2) Dichtheid omvat het aantal individuen per $\mathrm{m}^{2}$. Voor de statistische analyse is dichtheid log getransformeerd zodat de data dichterbij een normale verdeling komt. Hiervoor is bij elke dichtheid een vaste waarde opgeteld, omdat het logaritme van (monsterpunten met dichtheid) nul niet bestaat. In dit geval is het getal 10 opgeteld bij alle monsterpunten van de SIBES/Waddenmozaïek dataset en één bij de andere datasets; dit gaf een getallenreeks die normaal verdeeld is zonder extreme uitbijters. De variabele wordt in de analyse aangeduid als In_dichtheid.

(3) Biomassa is de totale gemeten $\mathrm{mg}$ aan versgewicht voor de WOT data en mg asvrij drooggewicht per $\mathrm{m}^{2}$ voor de andere datasets. Asvrij drooggewicht omvat alle organische stof in een monster. Voor de SIBES/Waddenmozaïek dataset geldt dat sommige erg kleine organismen of delen van organismen niet altijd verast zijn. Voor de statistische analyse is biomassa log getransformeerd zodat de data dichterbij een normale verdeling komt. Bij elk monsterpunt is een getal opgeteld om het logaritme van nul te voorkomen; bij alle monsterpunten van de SIBES/Waddenmozaïek was dit 0,1 en bij de andere datasets 1; dit gaf een getallenreeks die normaal verdeeld is zonder extreme uitbijters. De variabele wordt in de analyse aangeduid als In_biomassa.

(4) Ecologische rijkdom is gebruikt als een overkoepelende term van de boven beschreven variabelen (Ysebaert et al., 2016). Het gebruik van ecologische rijkdom is nuttig omdat soortenrijkdom, dichtheid en biomassa vaak sterk gecorreleerd zijn, maar één van de variabelen kan een grote uitschieter bevatten. Zo kan een monster een grote hoeveelheid zeer kleine individuen bevatten (hoge dichtheid) of kan juist één relatief zeer groot individu de biomassa sterk beïnvloeden. Voor ecologische rijkdom zijn soortenrijkdom, dichtheid en biomassa gestandaardiseerd door het gemiddelde voor elke variabele af te trekken van elke waarneming en te delen door de standaarddeviatie van de variabele. Door deze procedure hebben de drie variabelen allemaal een gemiddelde van nul en een standaarddeviatie van één. Ecologische rijkdom wordt vervolgens berekend als het gemiddelde van de waarden voor gestandaardiseerde soortenrijkdom, In_dichtheid en In_biomassa.

(5) Diversiteit is berekend als de Shannon-index, waarbij een grotere index correleert met een hogere biodiversiteit in een monster (Shannon \& Weaver, 1949). Voor de NIOZ/Waddenmozaiek is een aantal stappen uitgevoerd om teveel verschillende benamingen van (groepen) organismen te voorkomen. Deze dataset is het omvangrijkst en bevat hierdoor ook veel uiteenlopende soorten. Ten eerste zijn de taxa die zijn gedetermineerd op klasse of phylumniveau verwijderd. Dit zijn Ascidiacea, Chaetognatha, Gastropoda, Nemertea en Ophiuroidea. Vervolgens zijn alle genera waarvan meerdere soorten voorkwamen én ook het genusniveau (soortdeterminatie niet mogelijk) samengevoegd tot het genusniveau. Dit zijn Eteone flava en Eteone longa in Eteone spp., Eumida sanguinea in Eumida spp., Littorina littorea en Littorina obtusata in Littorina spp., Malacoceros fuliginosus en Malacoceros tetracerus in Malacoceros spp., Malmgrenia andreapolis in Malmgrenia spp., Microphthalmus sczelkowii in Microphthalmus spp., Nephtys caeca, Nephtys cirrosa, Nephtys hombergii en Nephtys longosetosa in Nephtys spp., Ophelia borealis en Ophelia limacina in Ophelia spp., Phyllodoce maculata en Phyllodoce mucosa in Phyllodoce spp. en Streblospio benedicti in Streblospio spp. Voor alle datasets geldt dat een selectie van de meest voorkomende soorten heeft plaatsgevonden om de dimensionaliteit van de dataset t.b.v. de multivariate analyse te verkleinen. Voor de analyse zijn enkel de soorten of soortgroepen geselecteerd die op minstens 5 procent van de stations voorkwamen. Vervolgens zijn de stations die door deze selectie geen soorten meer bevatten verwijderd. Diversiteit is berekend door een matrix te maken die voor elk station de biomassa voor elke soort weergeeft. Vervolgens is de proportie van elke soort binnen een monster berekend. Shannon-index is berekend per bemonsterd station met het vegan package in $\mathrm{R}$ (Oksanen et al., 2020). 


\subsubsection{Abiotische data}

\subsubsection{Droogvalduur}

Voor droogvalduur is gebruik gemaakt van een berekening met de tool Intertides voor het jaar 2017 (https://www.walterwaddenmonitor.org/en/tools/intertides/). Intertides kan droogvalduurkaarten genereren op basis van daadwerkelijk gemeten waterstanden. Het resultaat is een rasterbestand op het $20 \times 20$ m vaklodingenraster met waarden tussen de 0-100 procent droogvalduur.

\subsubsection{Stroomsnelheid, orbitaalsnelheid en zoutgehalte}

Stroomsnelheid en zoutgehalte zijn berekend met het door Deltares ontworpen Dutch Wadden Sea Model (DWSM) in Delft3D-Flexible Mesh (Van Weerdenburg \& Vroom, 2021). Stroomsnelheid werd bepaald uit de 2D versie van het model met ongeveer $100 \mathrm{~m} \times 100 \mathrm{~m}$ horizontale resolutie in het interessegebied voor modeluitvoer voor twee springtij-doodtij periodes van 23 juni tot 22 juli 2017. De getijcondities tijdens deze springtij-doodtij periodes zijn representatief voor het getij tussen 1 januari 2013 en 31 december 2017. Als uitvoerparameter werd het $99^{e}$ percentiel van de dieptegemiddelde stroomsnelheid gebruikt.

Saliniteit werd bepaald met een 3D versie van het model met 10 verticale $\sigma$-lagen en ongeveer $200 \mathrm{~m}$ x $200 \mathrm{~m}$ horizontale resolutie in het interessegebied. De gemiddelde saliniteit bij hoogwater en de variatie in saliniteit werden bepaald op basis van een 3D modelsimulatie voor 2017. Zowel de stroomsnelheid als orbitaalsnelheid werden geïnterpoleerd op een regelmatig $100 \mathrm{~m} \times 100 \mathrm{~m}$ rooster van het interessegebied (Van Weerdenburg \& Vroom, 2021).

De orbitaalsnelheid is verkregen uit modelresultaten van het SWAN-Kuststrook model. De maand maart 2020 werd gekozen als representatieve periode voor jaargemiddelde golfcondities. Als karakteristieke waarde voor de orbitaalsnelheid werd de RMS (Root Mean Square) waarde van de amplitude van de orbitaalbeweging bepaald. Deze waarde werd op een regelmatig $100 \mathrm{~m} \times 100 \mathrm{~m}$ rooster van het interessegebied geïnterpoleerd (Van Weerdenburg \& Vroom, 2021).

\subsubsection{Sediment}

Sedimentsamenstelling van de litorale ecotopen is onderdeel van de SIBES-data en voor sublitorale ecotopen van de Waddenmozaïek data.

\subsubsection{Omgevingsvariabelen koppelen aan bemonsteringslocaties}

Biotische datapunten zijn gekoppeld aan de abiotische data droogvalduur, stroomsnelheid, orbitaalsnelheid en zoutgehalte door de coördinaten van de monsterpunten te leggen over de rasters van de abiotische data met behulp R version 4.0.5 en de raster package (Hijmans, 2020; R Core Team, 2021). Hierbij wordt de waarde van een raster toegewezen aan de monsterpunten die binnen dat raster vallen. Sedimentsamenstelling kon voor de SIBES/Waddenmozaïek data direct gekoppeld worden aan de bodemdiergegevens, aangezien het sedimentmonster op dezelfde monsterpunten is genomen. Voor de WOT data is voor elk bemonsteringspunt het dichtstbijzijnde monsterpunt van het SIBES/Waddenmozaïekprogramma gezocht. Vervolgens werden de dichtstbijzijnde gemeten slibgehaltes en mediane korrelgrootte aan het WOT-monsterpunt toegewezen, als de sedimentmonsterpunten minder dan 1000 meter bij een WOT-monsterpunt vandaan lagen.

\subsection{Karakteristieke soorten}

De meest karakteristieke soorten per ecotoop zijn berekend aan de hand van de ecotopenkaart 2017. Hiervoor zijn de bemonsteringspunten van de SIBES/Waddenmozaïek data gebruikt, en is aan elk punt een type ecotoop gekoppeld. Ecotopen waar minder dan 10 monsterpunten in vielen zijn niet meegenomen. Dit zijn de pionierzone, pre-pionierzone, laagdynamisch zacht substraat in het supralitoraal en hoogdynamisch zacht substraat supralitoraal. 
Vervolgens is per soort de totale biomassa per ecotoop bepaald, en zijn de soorten die meer dan 5 procent van het totale gewicht uitmaken genoteerd. Daarnaast is ook per ecotoop het percentage voorkomen berekend door de aantal keer dat een soort gevonden werd in een monsterpunt te delen door het totaal aantal monsterpunten per ecotoop. We hebben karakteristieke soorten bepaald met de oude indeling van de ecotopen, omdat er nog geen beslissingen zijn genomen over de nieuwe indeling.

\subsection{Bepalen grenswaarden}

Alle onderstaande analyses zijn voor de drie biologische datasets apart uitgevoerd. Resultaten kunnen verschillen per biotische indicator en per dataset. Voordat de analyses werden uitgevoerd is een dataexploratie uitgevoerd (Bijlage 1).

\subsubsection{Habitat Mapping methode}

Voor het bepalen van grenswaarden in de abiotische variabelen is een eerder ontwikkelde methode gebruikt (Ysebaert et al., 2016). Deze methode heeft als doel inzicht te krijgen waar de grens ligt in een dataset op basis van de bodemdiergemeenschap, afhankelijk van de abiotische omgevingsvariabelen. De methode is geschikt wanneer er een drempelwaarde bepaald kan worden; als er onder en boven een bepaalde abiotische waarde gemiddeld lagere of juist hogere waardes van biotische indicatoren worden gevonden.

De analyse is uitgevoerd met de abiotische variabelen droogvalduur, stroomsnelheid, orbitaalsnelheid, saliniteit en sediment. Voor stroomsnelheid en orbitaalsnelheid is de analyse alleen uitgevoerd met het sublitorale deel van de verschillende biotische datasets (droogvalduur $<4 \%$ ). Voor droogvalduur is de data in verschillende delen gesplitst gebaseerd op de vier categorieën in het ZES.1 systeem, te weten sublitoraal, litoraal-laag, litoraal-midden en litoraal-hoog. Voor het bepalen van de grenswaarde tussen sublitoraal en litoraal-laag is biotische data gebruikt met een droogval tussen 0 en $25 \%$, tussen litoraal-laag en litoraal-midden met een droogval tussen 4 en $75 \%$ en tussen litoraal-midden en litoraal-hoog met een droogval tussen 25 en 85\%. Voor de Amelander Zeegat data is de analyse enkel uitgevoerd voor stroomsnelheid en orbitaalsnelheid omdat alle monsterpunten in het sublitoraal liggen. Voor de abiotische variabele slibgehalte zijn naast een analyse over de hele dataset ook analyses uitgevoerd op een selectie van de dataset; binnen sublitoraal laagdynamisch, binnen sublitoraal hoogdynamisch en binnen litoraal-laag, litoraal-midden en litoraal-hoog. Dynamiek bepaalt in sterke mate het slibgehalte in het sediment en daarom is onderzocht of er voor een hoge of lage dynamiek een afwijkende grenswaarde voor het slibgehalte gevonden werd.

Binnen een vooraf bepaalde range aan waardes van ieder van de abiotische variabelen zijn de biotische indicatoren van elke dataset telkens in tweeën gesplitst; lager of hoger dan deze grenswaarde. Vervolgens is een one-way ANOVA uitgevoerd om te testen of de gevormde groepen verschillen. Als maat voor dit verschil is de Residual sum of squares gedeeld door de Total sum of squares. Deze waarde noemen we de onverklaarde variantie. Deze waarde is 1 wanneer de bepaalde grenswaarde geen enkele variantie in de data kan verklaren en 0 wanneer alle variantie is verklaard door de bepaalde grenswaarde. Voor elke biotische indicator is per abiotische factor de laagste waarde (het "dal") van de onverklaarde variantie met bijbehorende abiotische waarde bepaald (Figuur 5). Als de dataset op basis van deze grenswaarde in twee delen wordt gesplitst, dan is het verschil tussen de twee groepen maximaal vergeleken met de variantie die binnen de groepen overblijft. Niet altijd komt er in de data een duidelijk minimum naar voren; in deze gevallen is er geen duidelijke waarde waarop de dataset op basis van de biotische data in tweeën is te splitsen. Wanneer de onverklaarde variantie voor geen enkele biotische indicator onder de 0,95 kwam in de analyse, hebben we deze mogelijke grenswaarde genegeerd. In dat geval kan een grenswaarde bepaald worden door een meer praktische aanpak zoals de eerder gebruikte grenswaarde, of een keuze voor de grootte van groepen die ontstaan of simpelweg voor de mediaan van de abiotische variabele.

Voor de sublitorale data van de SIBES/Waddenmozaïek, de WOT-Noordzee punten en Amelander Zeegat is er ook een analyse uitgevoerd gebaseerd op een combinatie van stroomsnelheid en orbitaalsnelheid. Hiervoor is dezelfde methode als hierboven gebruikt, maar is de grens om een 
dataset op te splitsen bepaald door zowel de stroomsnelheid als orbitaalsnelheid; de dataset werd opgesplitst wanneer stroomsnelheid óf orbitaalsnelheid boven een bepaalde waarde zat. Deze waardes liepen van 0.4 tot $1.6 \mathrm{~m} / \mathrm{s}$ voor stroomsnelheid en van 0.1 tot $0.7 \mathrm{~m} / \mathrm{s}$ voor orbitaalsnelheid in stapjes van 0.01 en alle combinaties van deze waardes. Vervolgens is de laagste waarde met bijbehorende stroomsnelheid en orbitaalsnelheid bepaald op dezelfde wijze als hierboven beschreven.

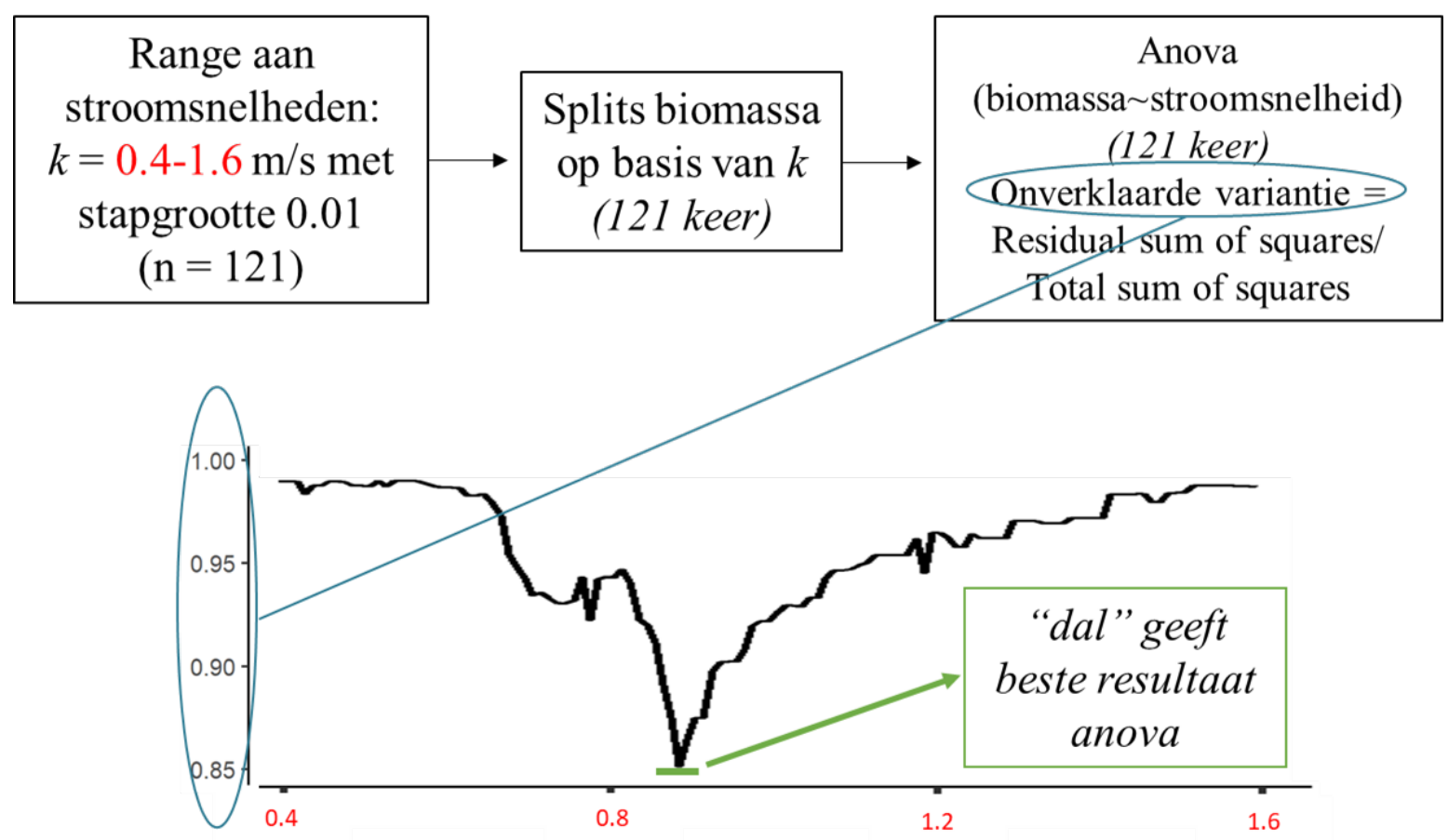

Figuur $5 \quad$ Voorbeeld van de gebruikte methode voor bepalen van grenswarden. Als voorbeeld is voor de abiotische variabele de stroomsnelheid en voor de biotische variabele de biomassa gebruikt. Onverklaarde variantie uit de anova tabel staat op de $y$-as. Het "dal" geeft een mogelijke grenswaarde aan. Wanneer deze grenswaarde gebruikt zal worden voor het onderscheid tussen laag-en hoogdynamische ecotopen zal in dit voorbeeld $\sim 15 \%$ van de variantie verklaard worden door de groepen.

\subsubsection{Testen grenswaarden m.b.v. lineaire regressiemodellen}

Wanneer er een nieuwe grenswaarde werd bepaald met behulp van de habitat mapping methode, is getest of de nieuwe grenswaarde de data beter verklaarde dan de oude grenswaarde in het ZES.1. Hiervoor zijn drie verschillende lineaire modellen opgesteld met als responsvariabele ecologische rijkdom of diversiteit en de verklarende variabele de groepen met verschillende grenswaarden. Voor de WOT data zijn dichtheid en biomassa gebruikt als verklarende variabelen in de lineaire modellen. De drie modellen waren:

- Nulmodel: alle waarnemingen behoren tot dezelfde groep

- Model 1: scheiding in twee groepen op basis van de oude ZES grenswaarden

- Model 2: scheiding in twee groepen op basis van de nieuwe grenswaarden

Het beste model is bepaald door middel van de AIC en (adjusted) r-squared.

\subsubsection{Testen grenswaarden m.b.v. multivariate analyse (RDA)}

De nieuwe grenswaarden zijn ook getest op de soortsamenstelling met behulp van multivariate data analyse. Hiervoor heeft eerst dezelfde dataselectie procedure plaatsgevonden als voor het berekenen van diversiteit, waarbij sommige taxa zijn verwijderd en sommige soorten zijn samengevoegd tot het genusniveau (zie paragraaf 3.1.1.4. sectie (5)). Met deze selectie is een matrix gemaakt die voor elk station de biomassa per soort weergeeft. Vervolgens is een redundancy analysis (RDA) uitgevoerd met de vierdemachtswortel van de soortsamenstelling als responsvariabele en de oude of nieuwe groepsindeling als verklarende variabele met behulp van het vegan $\mathrm{R}$ package (Oksanen et al., 2020). Getest is of de nieuwe grenswaarden meer variantie verklaren. In de output van deze analyse geeft de 
"constrained"-waarde de hoeveelheid verklaarde variantie aan door de verklarende variabelen en de "unconstrained"-waarde de residue variantie. De nieuwe grenswaarden zijn beter dan de oude wanneer de "constrained"-waarde groter is voor de nieuwe grenswaarde dan voor de oude grenswaarde. Significantie van het model is getest met een ANOVA. 


\section{Resultaten}

\subsection{Karakteristieke soorten}

Gebruikmakend van de ecotopenkaart uit 2017 hebben we de karakteristieke soorten per ecotoop op een rijtje gezet voor zowel biomassa (Tabel 1) als voorkomen (Tabel 2), gebruikmakend van de SIBES/Waddenmozaïek dataset.

Tabel 1 Overzicht van karakteristieke soorten per ecotoop in de Waddenzee gebruikmakend van de SIBES/Waddenmozaïek dataset. Alleen taxa die meer dan 5 procent van het totale gewicht uitmaken in een ecotoop zijn genoemd.

\begin{tabular}{|c|c|}
\hline Ecotoop (n=aantal monsterpunten) & Karakteristieke soorten ( $\%$ totale biomassa) \\
\hline $\begin{array}{l}\text { Hoogdynamisch zacht substraat in het diepe sublitoraal } \\
(n=317)\end{array}$ & Ensis leei (80), Lanice conchilega (14) \\
\hline $\begin{array}{l}\text { Hoogdynamisch zacht substraat in het ondiepe } \\
\text { sublitoraal }(n=195)\end{array}$ & Ensis leei (84) \\
\hline $\begin{array}{l}\text { Laagdynamisch zacht substraat in het diepe sublitoraal } \\
(n=12)\end{array}$ & Ensis leei (60), Mya arenaria (35) \\
\hline $\begin{array}{l}\text { Laagdynamisch zacht substraat in het ondiepe sublitoraal } \\
(n=781)\end{array}$ & Mya arenaria (42), Ensis leei (35), Peringia ulvae (8) \\
\hline Hoogdynamisch fijnzandig litoraal $(n=293)$ & $\begin{array}{l}\text { Ensis leei (41), Cerastoderma edule (24), Arenicola marina (10), Scoloplos armiger } \\
\text { (9) }\end{array}$ \\
\hline Laagdynamisch fijnzandig laag litoraal $(n=1480)$ & $\begin{array}{l}\text { Ensis leei (33), Arenicola marina (17), Cerastoderma edule (13), Mya arenaria (11), } \\
\text { Lanice conchilega ( } 8 \text { ) }\end{array}$ \\
\hline Laagdynamisch slibrijk laag litoraal $(n=90)$ & $\begin{array}{l}\text { Mya arenaria (51), Cerastoderma edule (18), Heteromastus filiformis (8), Ensis leei } \\
\text { (7) }\end{array}$ \\
\hline Laagdynamisch fijnzandig middelhoog litoraal $(n=1632)$ & $\begin{array}{l}\text { Cerastoderma edule (22), Arenicola marina (19), Mya arenaria (14), Hediste } \\
\text { diversicolor (10), Heteromastus filiformis (6), Peringia ulvae (5) }\end{array}$ \\
\hline Laagdynamisch slibrijk middelhoog litoraal $(n=607)$ & $\begin{array}{l}\text { Mya arenaria (31), Cerastoderma edule (18), Hediste diversicolor (11), } \\
\text { Heteromastus filiformis (9), Limecola balthica (7), Peringia ulvae (7), Corophiidae } \\
(6)\end{array}$ \\
\hline Laagdynamisch fijnzandig hoog litoraal $(n=13)$ & $\begin{array}{l}\text { Peringia ulvae (35), Hediste diversicolor (17), Pygospio elegans (14), Mya arenaria } \\
(10) \text {, Arenicola marina (7), Oligochaeta (6), Limecola balthica (5) }\end{array}$ \\
\hline
\end{tabular}




\begin{tabular}{|c|c|}
\hline \multicolumn{2}{|c|}{$\begin{array}{l}\text { Tabel } 2 \text { Overzicht karakteristieke soorten per ecotoop in de Waddenzee gebruikmakend van de } \\
\text { SIBES/Waddenmozaïek dataset. Alleen taxa die in meer dan } 25 \text { procent van de monsters voorkomen per } \\
\text { ecotoop zijn genoemd. }\end{array}$} \\
\hline Ecotoop ( $n=$ aantal monsterpunten) & Karakteristieke soorten (\% voorkomen in de monsters) \\
\hline $\begin{array}{l}\text { Hoogdynamisch zacht substraat in het diepe sublitoraal } \\
(\mathrm{n}=317)\end{array}$ & $\begin{array}{l}\text { Capitella sp. (52), Heteromastus filiformis (47), Bathyporeia sp. (47), Scoloplos } \\
\text { armiger (38), Nephtys sp. (32), Magelona sp. (26) }\end{array}$ \\
\hline $\begin{array}{l}\text { Hoogdynamisch zacht substraat in het ondiepe } \\
\text { sublitoraal }(n=195)\end{array}$ & $\begin{array}{l}\text { Capitella sp. (56), Scoloplos armiger (56), Bathyporeia sp. (45), Pygospio elegans } \\
\text { (40), Ensis leei (38), Heteromastus filiformis (34), Nephtys sp. (30), Spio sp. (29) }\end{array}$ \\
\hline $\begin{array}{l}\text { Laagdynamisch zacht substraat in het diepe sublitoraal } \\
(\mathrm{n}=12)\end{array}$ & $\begin{array}{l}\text { Heteromastus filiformis (83), Oligochaeta (58), Capitella sp. (50), Ensis leei (50), } \\
\text { Pygospio elegans (42), Cirratulidae (33), Spio sp. (33), Alitta succinea (25), } \\
\text { Limecola balthica (25), Scoloplos armiger (25) }\end{array}$ \\
\hline $\begin{array}{l}\text { Laagdynamisch zacht substraat in het ondiepe sublitoraal } \\
(\mathrm{n}=781)\end{array}$ & $\begin{array}{l}\text { Scoloplos armiger (62), Pygospio elegans (56), Heteromastus filiformis (55), } \\
\text { Capitella sp. (54), Cirratulidae (42), Ensis leei (35), Spio sp. (29) }\end{array}$ \\
\hline Hoogdynamisch fijnzandig litoraal $(n=293)$ & $\begin{array}{l}\text { Scoloplos armiger (80), Pygospio elegans (70), Urothoe sp. (45), Capitella sp. (41), } \\
\text { Bathyporeia sp. (35), Heteromastus filiformis (29) }\end{array}$ \\
\hline Laagdynamisch fijnzandig laag litoraal $(n=1480)$ & $\begin{array}{l}\text { Pygospio elegans (78), Scoloplos armiger (72), Heteromastus filiformis (54), } \\
\text { Capitella sp. (52), Cirratulidae (40), Arenicola marina (34), Urothoe sp. (24), Ensis } \\
\text { leei (28), Eteone sp. (26) }\end{array}$ \\
\hline Laagdynamisch slibrijk laag litoraal $(n=90)$ & $\begin{array}{l}\text { Heteromastus filiformis (94), Cirratulidae (53), Pygospio elegans (44), Hediste } \\
\text { diversicolor (31), Oligochaeta (29), Limecola balthica (28), Mya arenaria (26) }\end{array}$ \\
\hline Laagdynamisch fijnzandig middelhoog litoraal $(n=1632)$ & $\begin{array}{l}\text { Pygospio elegans (87), Heteromastus filiformis (66), Scoloplos armiger (65), Eteone } \\
\text { sp. (55), Cirratulidae (53), Limecola balthica (53), Hediste diversicolor (52), } \\
\text { Arenicola marina (48), Capitella sp. (45), Oligochaeta (44), Urothoe sp. (42), } \\
\text { Nereididae (30), Cerastoderma edule (30) }\end{array}$ \\
\hline Laagdynamisch slibrijk middelhoog litoraal $(n=607)$ & $\begin{array}{l}\text { Heteromastus filiformis (83), Pygospio elegans (69), Oligochaeta (62), Limecola } \\
\text { balthica (59), Cirratulidae (57), Hediste diversicolor (56), Corophiidae (47), Peringia } \\
\text { ulvae (38), Eteone sp. (36), Alitta succinea (28), Mya arenaria (26), Cerastoderma } \\
\text { edule (26) }\end{array}$ \\
\hline Laagdynamisch fijnzandig hoog litoraal $(n=13)$ & $\begin{array}{l}\text { Peringia ulvae (100), Pygospio elegans (100), Hediste diversicolor (92), Oligochaeta } \\
\text { (92), Abra tenuis (85), Eteone sp. (69), Corophiidae (62), Limecola balthica (62), } \\
\text { Capitella sp. (54), Arenicola marina (31), Bathyporeia sp. (31), Fabricia stellaris } \\
\text { stellaris (31), Heteromastus filiformis (31), Nereididae (31) }\end{array}$ \\
\hline
\end{tabular}




\subsection{Grenswaarden}

Met de habitat mapping methode zijn nieuwe grenswaarden gevonden of bestaande grenswaarden bevestigd aan de hand van de bodemdiergemeenschap. De hele analyse is uitgevoerd voor de drie beschreven datasets, waarbij voor het Amelander Zeegat alleen gekeken is naar stroomsnelheid, orbitaalsnelheid en de combinatie van de twee. Gedetailleerde uitkomsten van de habitat methode zijn te vinden, per dataset, in tabellen in bijlage 2 . De resultaten zijn samengevat in Tabel 3 en per abiotische variabele worden de bevindingen kort toegelicht.

\subsubsection{Droogvalduur}

Er is geen duidelijke grenswaarde tussen sublitoraal en litoraal-laag gevonden in de SIBES/Waddenmozaïek data (Tabel 3, Tabel 7, Tabel 8). De WOT data suggereert dat een grenswaarde met een zeer lage droogvalduurpercentage van 0.1-0.2\% de meeste variantie verklaart (Figuur 7). De gehanteerde huidige grenswaarde in het ZES.1 systeem is 4\% droogvalduur en zougehandhaafd kunnen blijven. Grenswaarden tussen litoraal-laag en litoraal-midden en tussen litoraal-midden en litoraal-hoog werden gevonden; voor beide analyses werd het sterkste resultaat gevonden voor dichtheid (Tabel 7, Tabel 8, Figuur 6, Figuur 7). Kijkend naar alle variabelen zou de grenswaarde tussen litoraal-laag en litoraal-midden op een droogvalduur van ongeveer $30 \%$ komen voor zowel de SIBES/Waddenmozaïek als de WOT data. Dit ligt relatief dicht bij de grenswaarde uit het ZES. 1 van 25\%. De grenswaarde tussen midden-litoraal en hoog-litoraal voor de SIBES/Waddenmozaïek zou op ongeveer $40 \%$ droogvalduur komen. Dit is fors lager dan de ZES. 1 grenswaarde die nu op $75 \%$ ligt. Voor de WOT data is de grenswaarde tussen midden-litoraal en hoog-litoraal vergelijkbaar met die van tussen litoraal-laag en -midden; rond de $30 \%$ droogvalduur (Tabel 3).

De habitat methode suggereert een aanpassing van de grens tussen litoraal-midden en litoraal-hoog naar $\sim 40 \%$. Enkel deze grens is daarom getest ten opzichte van de oude grenswaarde van droogvalduur van $75 \%$. Voor de SIBES/Waddenmozaïek data levert de nieuwe grenswaarde tussen litoraal-midden en litoraal-hoog van droogvalduur $40 \%$ een verbetering op voor zowel ecologische rijkdom als diversiteit (Tabel 10). Voor de WOT data is alleen een verbetering te zien voor biotische variabele dichtheid maar niet voor biomassa (Tabel 11). De nieuwe grenswaarden zijn ook getest op de soortsamenstelling voor de SIBES/Waddenmozaïek data met behulp van multivariate data analyse. De nieuwe grenswaarden geven een kleine verbetering in het verklaren van de variantie in de soortsamenstelling; er wordt ongeveer 1 procent meer variantie verklaard (Tabel 3, Tabel 13). 


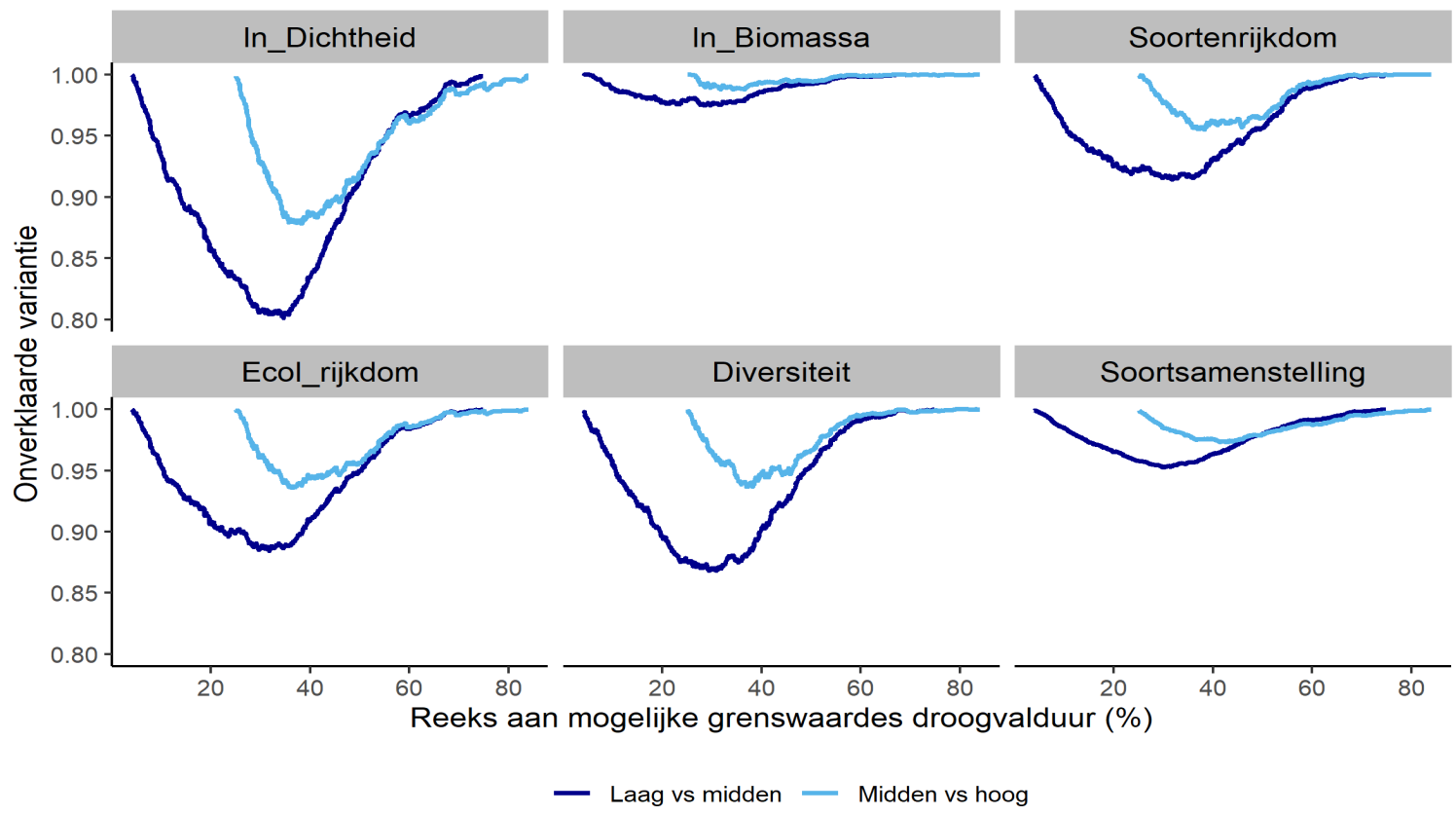

Figur $6 \quad$ Onverklaarde variantie op de $y$-as met mogelijke grenswaarden voor de droogvalduur tussen litoraal-laag vs litoraal-midden en litoraal-midden vs litoraal-hoog voor de SIBES/Waddenmozaïek data. Het "dal" geeft een mogelijke grenswaarde aan. De onverklaarde variantie van soortsamenstelling is berekend door uitvoeren van een RDA (multivariate analyse), de onverklaarde variantie van de andere biotische variabelen met een anova.

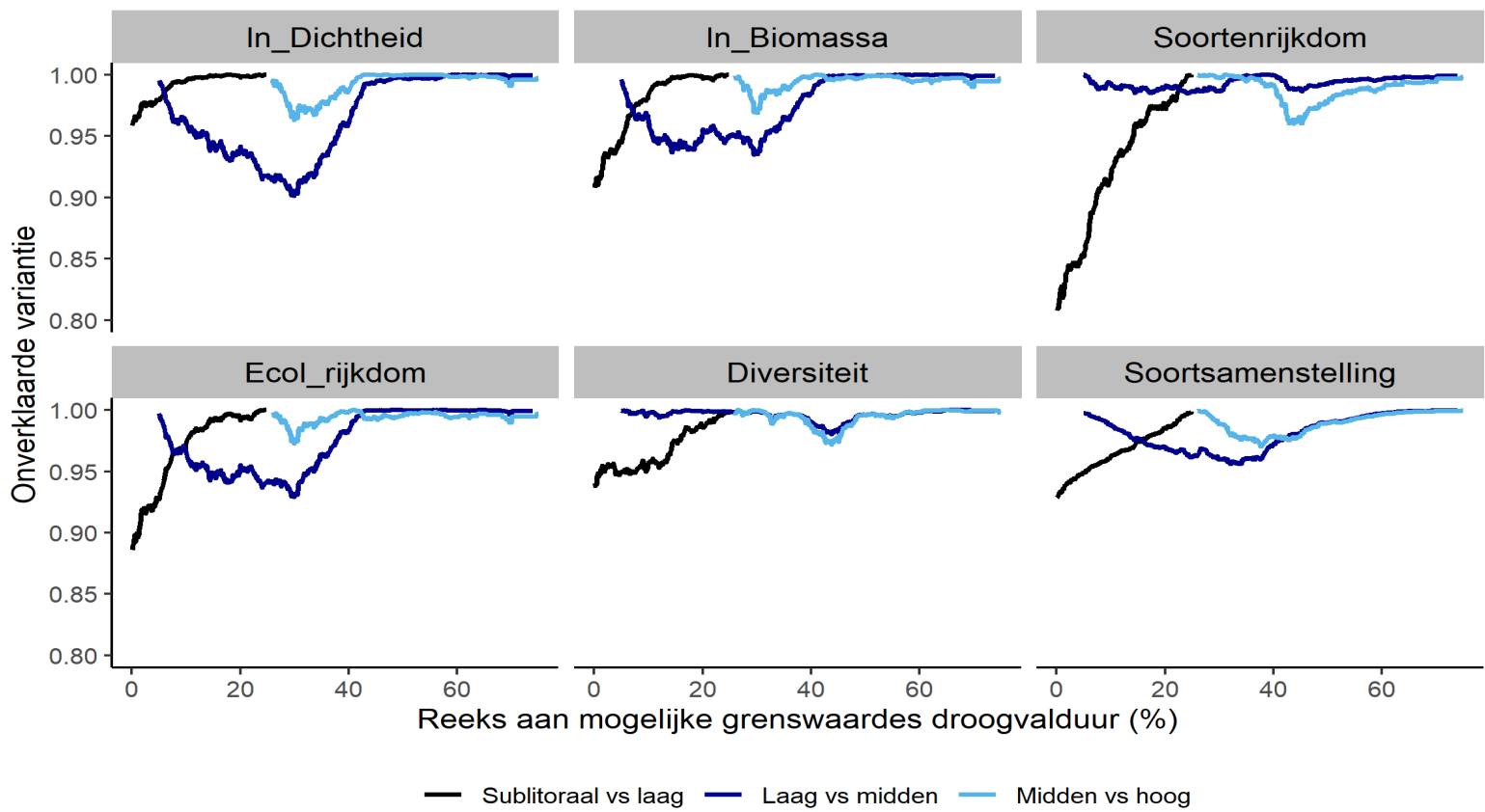

Figur $7 \quad$ Onverklaarde variantie op de $y$-as met mogelijke grenswaarden voor de droogvalduur tussen sublitoraal vs litoraal-laag, litoraal-laag vs litoraal-midden en litoraal-midden vs litoraal-hoog voor de WOT dataset. Het "dal" geeft een mogelijke grenswaarde aan. De onverklaarde variantie van soortsamenstelling is berekend door uitvoeren van een RDA (multivariate analyse), de onverklaarde variantie van de andere biotische variabelen met een anova. 


\subsubsection{Stroomsnelheid en orbitaalsnelheid - zwakke versus sterke stroming en golven}

Gevonden grenswaarden om zwakke van sterke stroming te onderscheiden voor de SIBES/Waddenmozaïek, WOT (Noordzeepunten) en Amelanderzeegat datasets zijn respectievelijk $\sim 1.0, \sim 0.8$ en $\sim 0.9 \mathrm{~m} / \mathrm{s}$ (Tabel 3, Tabel 7, Tabel 8, Tabel 9, Figuur 8, Figuur 10, Figuur 11). Voor de WOT data werd alleen een duidelijke grenswaarde gevonden in de Noordzee-meetpunten (Figuur 9). Voorgesteld wordt de huidige grenswaarde van $0,8 \mathrm{~m} / \mathrm{s}$ te handhaven.

Grenswaarden voor orbitaalsnelheid (zwakke versus sterke goven) werden in de Noordzee-datapunten van de WOT data en de Amelander Zeegat data gevonden (Tabel 7, Tabel 8, Tabel 9). De grenswaarde in de WOT data bevestigt min of meer de gebruikte grens in het ZES.1 systeem; de grenswaarde ligt dichtbij de $0,25 \mathrm{~m} / \mathrm{s}$ (Figuur 10). De grenswaarde die uit de analyse van de Amelander Zeegat data komt ligt hoger dan de grenswaarde in het ZES.1;0,5 m/s. Dit blijkt vooral uit de biotische variabele diversiteit (Shannon-Wiener) (Figuur 11).

Lineaire modellen zijn opgesteld om te bepalen of de nieuwe grenswaarden meer variatie verklaren dan de oude grenswaarden. De nieuwe grenswaarde voor stroomsnelheid geeft een wisselend beeld; voor zowel de SIBES/Waddenmozaïek data als de Amelander Zeegat data geeft de nieuwe grenswaarde voor desbetreffende dataset een verbetering van de verklaarde variatie voor ecologische rijkdom, maar niet voor diversiteit (Tabel 10, Tabel 12). De nieuwe grenswaarde voor het Amelander Zeegat geeft ook een verbetering in de verklaring van de soortsamenstelling (Tabel 14). De WOT data is niet getest omdat de gevonden grenswaarde in deze dataset overeen kwam met de al gebruikte grenswaarde van $0,8 \mathrm{~m} / \mathrm{s}$ voor stroomsnelheid.

De nieuwe grenswaarde van $0,5 \mathrm{~m} / \mathrm{s}$ voor orbitaalsnelheid verklaart de biotische indicatoren ecologische rijkdom en met name diversiteit van het Amelander Zeegat beter (Tabel 12). Dit resulteert in een significant grotere diversiteit van monsterpunten in gebieden met sterke golven ten opzichte van gebieden met zwakkere golven (Figuur 12). 


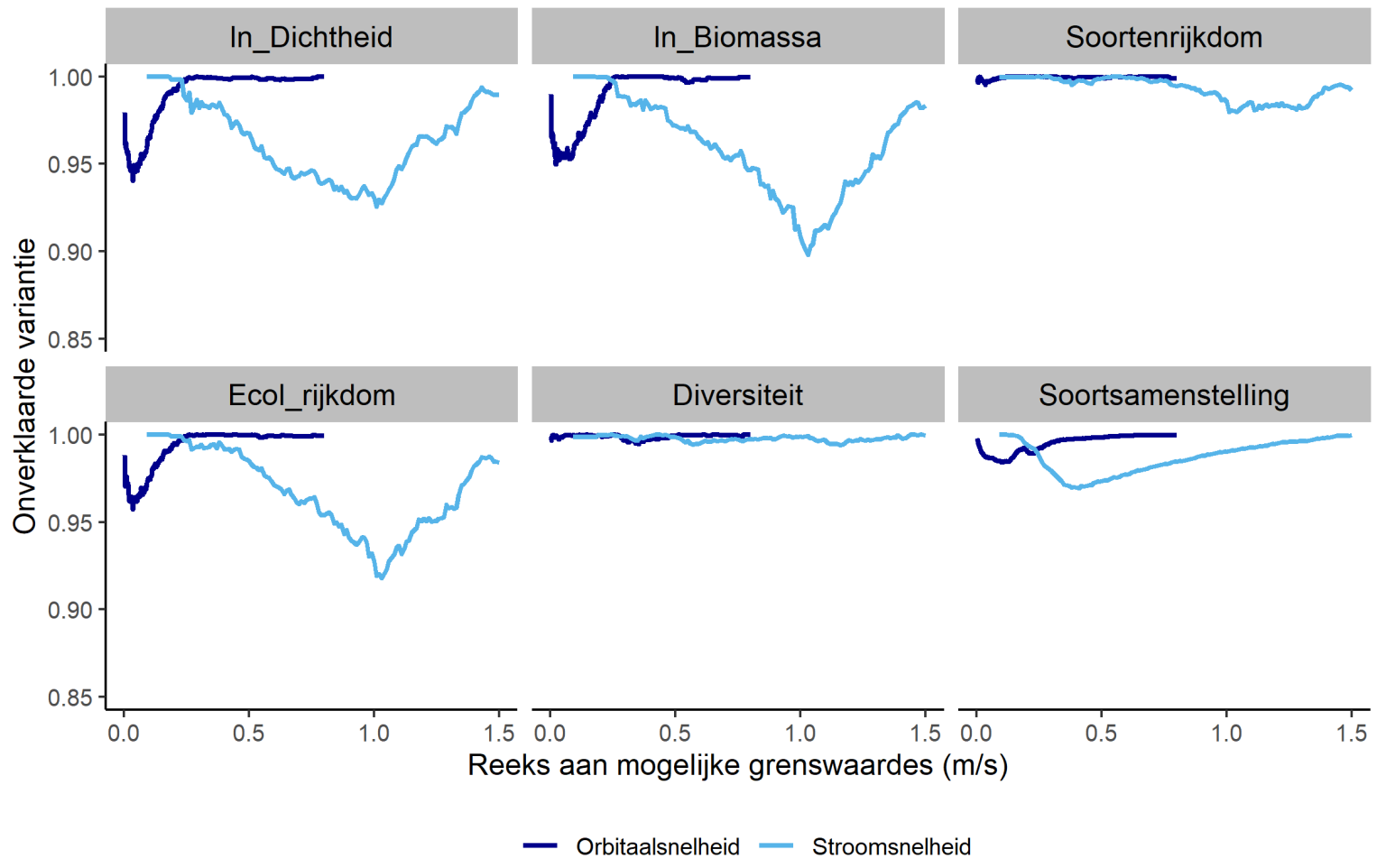

Figur $8 \quad$ Onverklaarde variantie op de $y$-as met mogelijke grenswaarden voor de stroomsnelheid (lichtblauw) en orbitaalsnelheid van golven (donkerblauw) van de SIBES/Waddenmozaïek dataset. Het "dal" geeft een mogelijke grenswaarde aan. De onverklaarde variantie van soortsamenstelling is berekend door uitvoeren van een RDA (multivariate analyse), de onverklaarde variantie van de andere biotische variabelen met een anova.

\section{Waddenzee-punten}

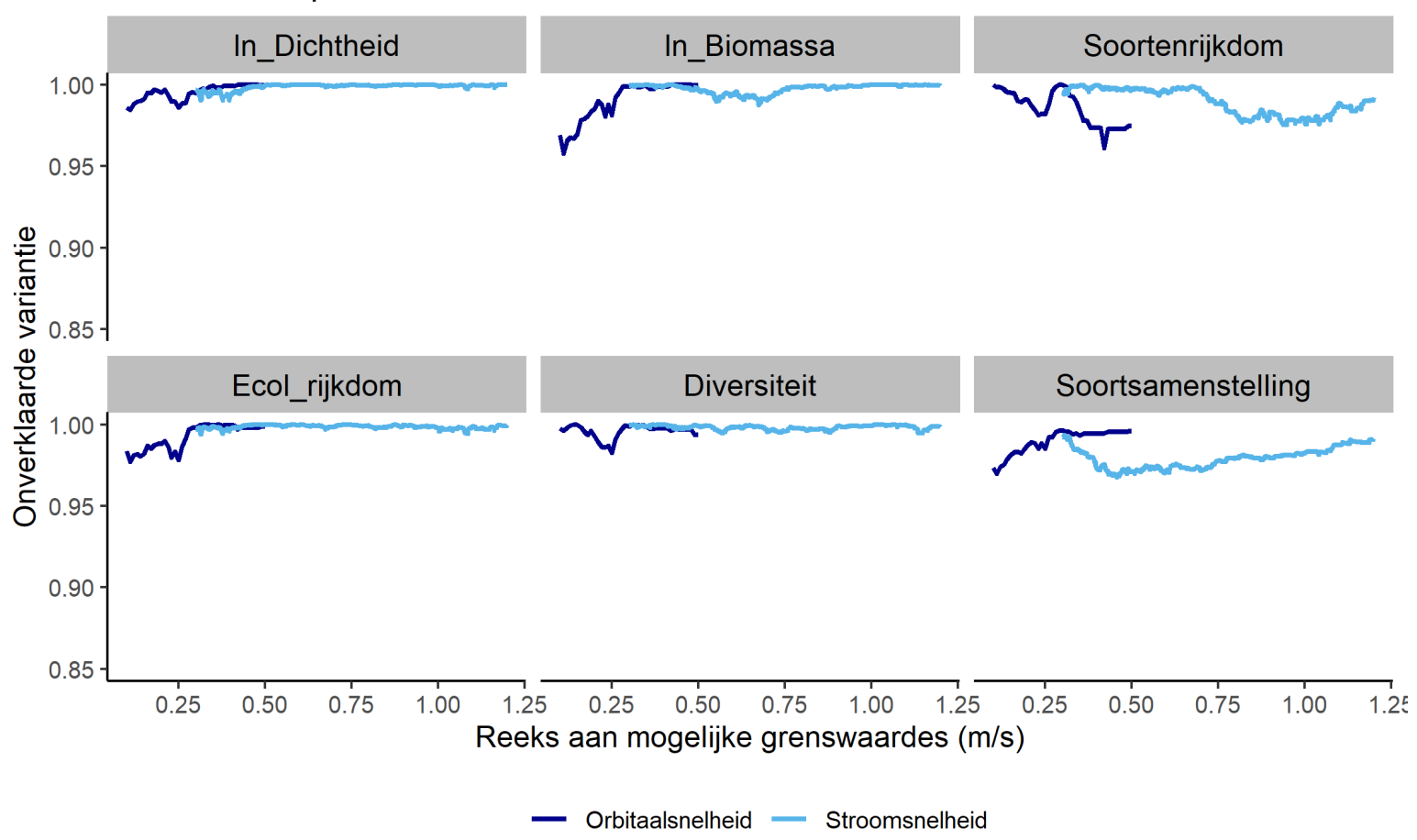

Figuur 9 Onverklaarde variantie op de $y$-as met mogelijke grenswaarden voor de stroomsnelheid (lichtblauw) en orbitaalsnelheid van golven (donkerblauw) van de WOT dataset, Waddenzee-punten. Het "dal" geeft een mogelijke grenswaarde aan. De onverklaarde variantie van soortsamenstelling is berekend door uitvoeren van een RDA (multivariate analyse), de onverklaarde variantie van de andere biotische variabelen met een anova. 
Noordzee-punten

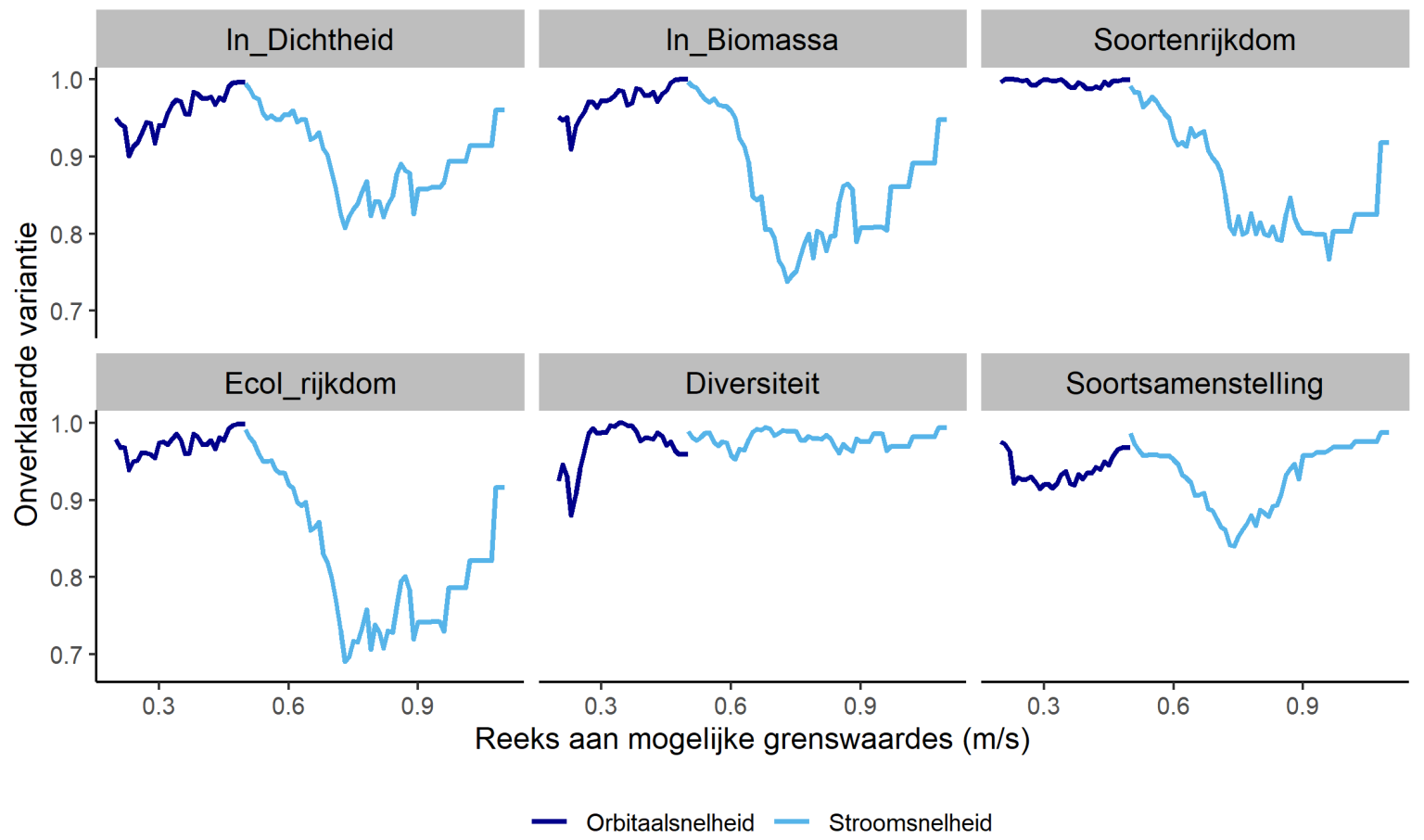

Figur 10 Onverklaarde variantie op de $y$-as met mogelijke grenswaarden voor de stroomsnelheid (lichtblauw) en orbitaalsnelheid van golven (donkerblauw) van de WOT dataset, Noordzee-punten. Het "dal" geeft een mogelijke grenswaarde aan. De onverklaarde variantie van soortsamenstelling is berekend door uitvoeren van een RDA (multivariate analyse), de onverklaarde variantie van de andere biotische variabelen met een anova.

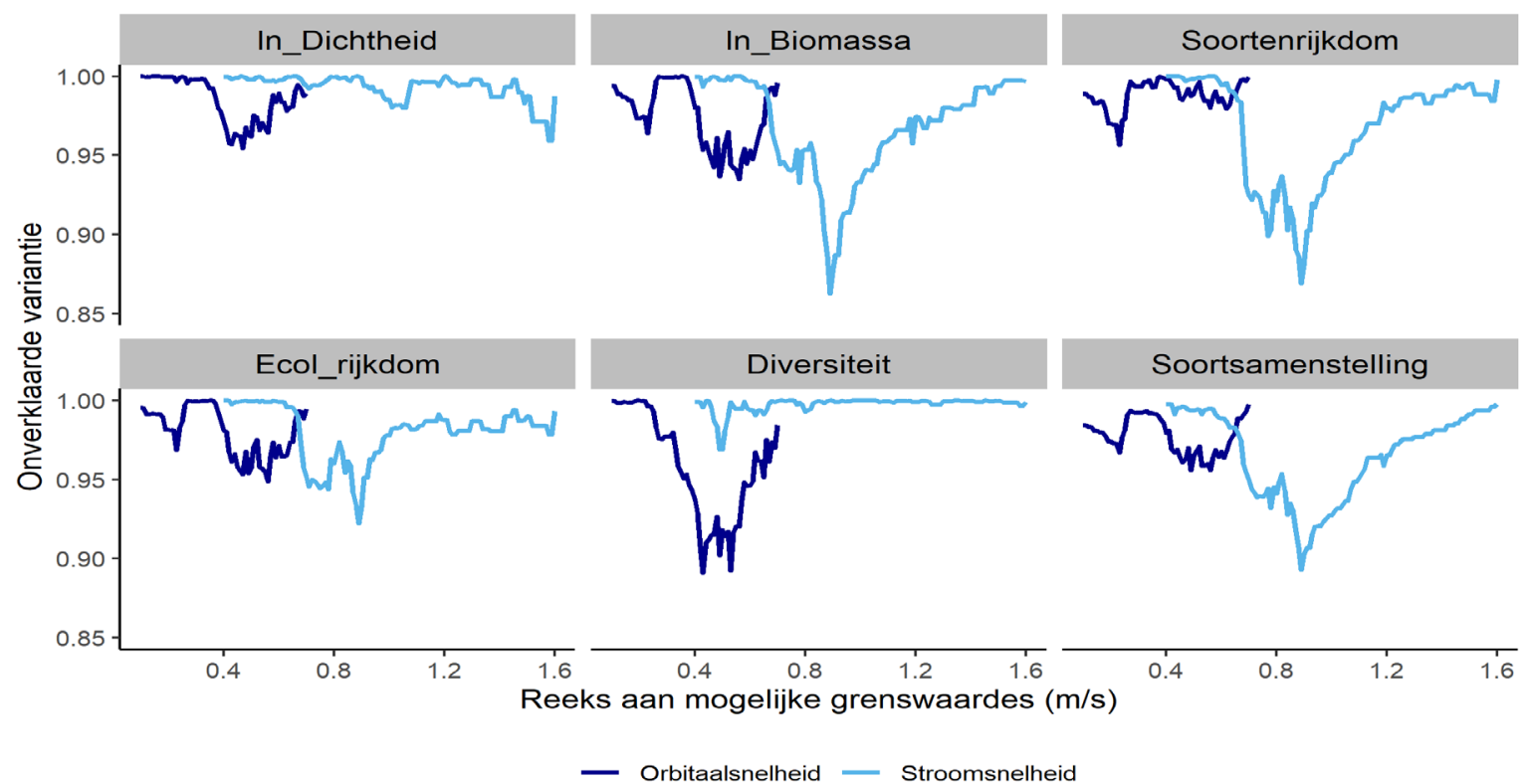

Figuur 11 Onverklaarde variantie op de $y$-as met mogelijke grenswaarden voor de stroomsnelheid (lichtblauw) en orbitaalsnelheid van golven (donkerblauw) van het Amelander Zeegat. Het "dal" geeft een mogelijke grenswaarde aan. De onverklaarde variantie van soortsamenstelling is berekend door uitvoeren van een RDA (multivariate analyse), de onverklaarde variantie van de andere biotische variabelen met een anova. 


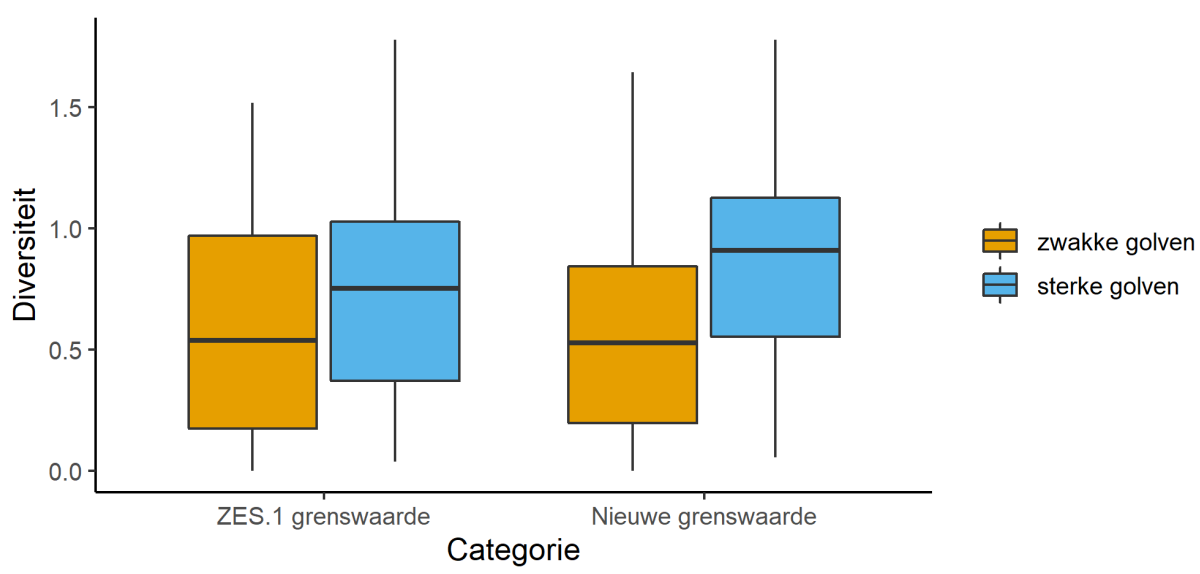

Figuur 12 Diversiteit voor zwakke vs sterke golven op de basis van de huidige ZES.1 grenswaarde van $0,25 \mathrm{~m} / \mathrm{s}$ (links) en op basis van de voorgestelde nieuwe grenswaarde van $0,5 \mathrm{~m} / \mathrm{s}$ uit de Amelander Zeegat data (rechts). De nieuwe grenswaarde resulteert in een groter verschil in diversiteit tussen de beide groepen.

\subsubsection{Combinatie stroomsnelheid en orbitaalsnelheid - laagdynamisch versus hoogdynamisch}

In het ecotopenstelsel wordt een combinatie gebruikt van stroomsnelheid en orbitaalsnelheid voor het sublitoraal. Voor de WOT data is dit onderdeel alleen uitgevoerd voor meetpunten in de Noordzee. Ecotopen worden in het ZES. 1 als hoogdynamisch gekarakteriseerd wanneer stroomsnelheid óf orbitaalsnelheid boven een bepaalde grenswaarde zit. De combinatie-analyse waarbij zowel stroomsnelheid en orbitaalsnelheid zijn gebruikt geeft voor beide abiotische variabelen een grenswaarde waarmee, wanneer de data in tweeën gesplitst zou worden, de meeste variantie verklaard zou worden.

Grenswaarden om laagdynamische van hoogdynamische ecotopen te onderscheiden worden in alle drie de datasets gevonden (Tabel 7, Tabel 8, Tabel 9). Voor alle datasets komt min of meer dezelfde grenswaarde voor stroomsnelheid naar voren als bij de analyse waarin naar stroomsnelheid alleen wordt gekeken (voor SIBES/Waddenmozaïek is alleen de grenswaarde voor diversiteit afwijkend lager en voor Amelander zeegat zijn de grenswaarden voor dichtheid en diversiteit afwijkend hoger), Tabel 3. De grenswaarde voor orbitaalsnelheid is verschillend van de eerdere aparte analyse, behalve voor het Amelander Zeegat waar de grenswaarde op 0,5 m/s blijft (Tabel 3, Figuur 15). Bij de SIBES/Waddenmozaïek dataset komt nu wel een grenswaarde voor orbitaalsnelheid naar voren van $0,5 \mathrm{~m} / \mathrm{s}$ (Figuur 13). Bij de WOT dataset ligt in de combinatie-analyse de grenswaarde voor orbitaalsnelheid hoger dan eerst; rond de $0,5 \mathrm{~m} / \mathrm{s}$ in plaats van rond de 0,25 m/s (Figuur 14).

De nieuwe dynamiekgrenswaarden leveren een verbetering op ten opzichte van de oude grenswaarden voor tenminste één biotische variabele voor zowel de SIBES/Waddenmozaïek data als de WOT data (Tabel 10, Tabel 11, Tabel 13). Voor de SIBES/Waddenmozaïekdata komt de ecologische rijkdom tussen de twee dynamiekklasses laag- en hoogdynamisch iets meer uit elkaar te liggen, waarbij laagdynamische ecotopen een iets hogere ecologische rijkdom hebben (Figuur 16). Vanwege de twee gevonden grenswaarden voor orbitaalsnelheid uit de WOT dataset (Noordzeepunten), is bij het testen van de resultaten ook een mogelijkheid met drie dynamiekklasses getest; naast laag- en hoogdynamisch ook een tussenklasse genaamd middel-dynamisch (Tabel 3). Het model met drie dynamiekklasses gaf een beter resultaat voor het model met dichtheid, maar niet voor het model met biomassa (Tabel 11). Wanneer de drie dynamiekgroepen op de WOT data worden toegepast, hebben de middel-dynamische ecotopen gemiddeld een hogere dichtheid dan de laag- en hoogdynamische ecotopen (Figuur 17). De nieuwe dynamiekgrenswaarden voor de Amelander Zeegat data zijn moeilijk te testen, omdat de ZES. 1 klasse-indeling slechts in 3 van de 206 meetpunten laagdynamische ecotopen oplevert en hierdoor een statistische test niet zinvol is. 


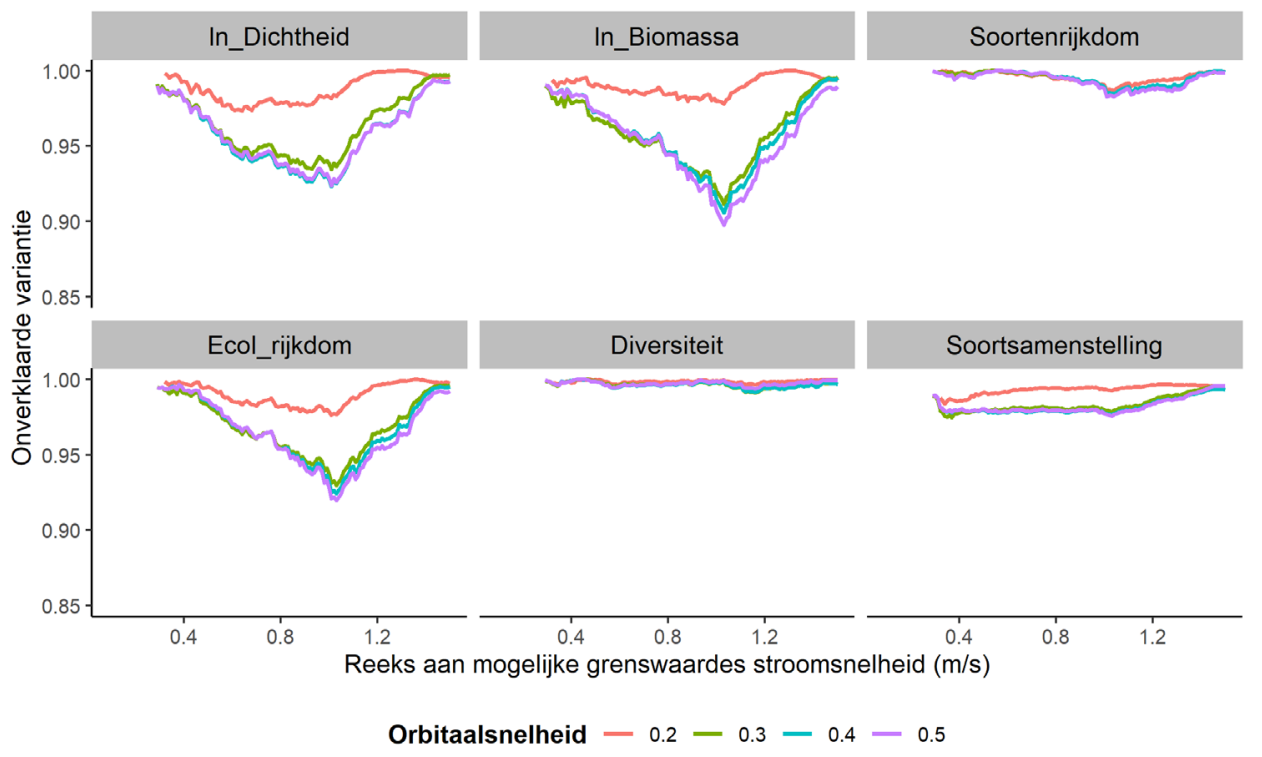

Figur 13 Onverklaarde variantie uit de anova tabel op de y-as met mogelijke grenswaarden voor de stroomsnelheid voor de SIBES/Waddenmozaïek data. In kleur zijn een aantal grenswaarden voor orbitaalsnelheid aangegeven. Het "dal" geeft een mogelijke grenswaarde aan. De onverklaarde variantie van soortsamenstelling is berekend door uitvoeren van een RDA (multivariate analyse), de onverklaarde variantie van de andere biotische variabelen met een anova.

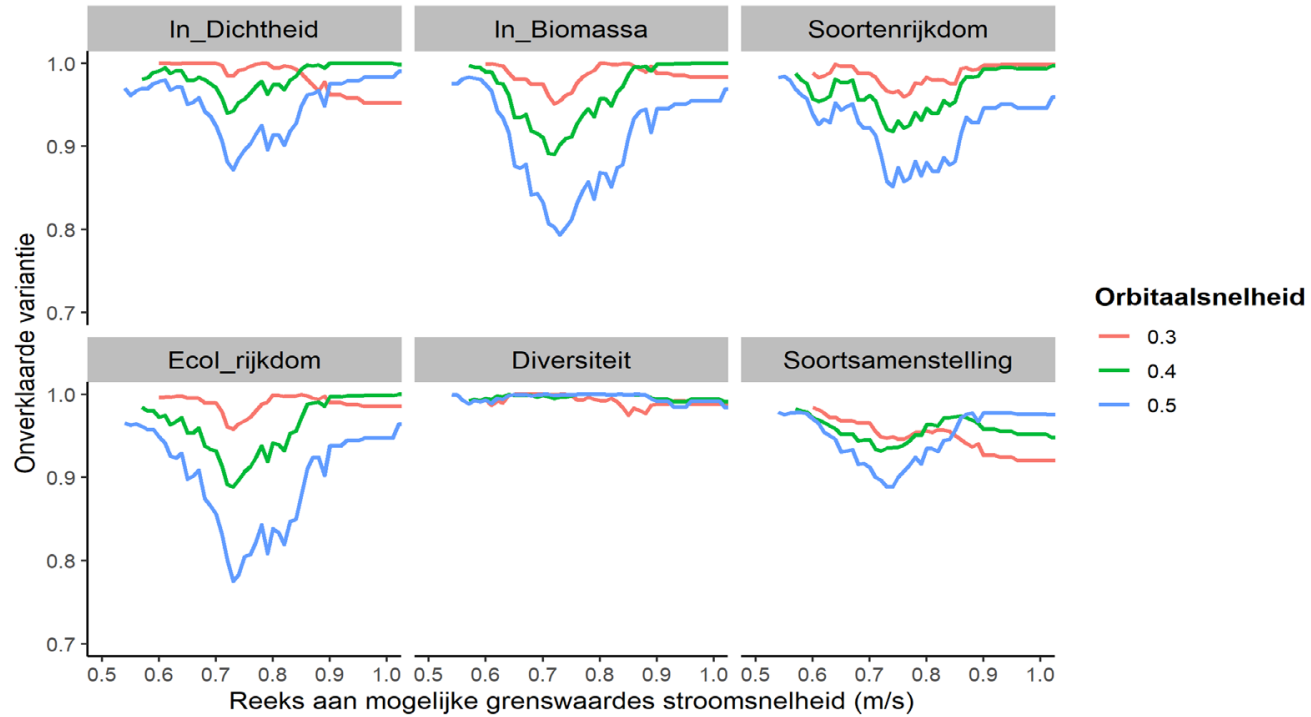

Figuur 14 Onverklaarde variantie uit de anova tabel op de $y$-as met mogelijke grenswaarden voor de stroomsnelheid voor de WOT dataset Noordzee-punten. In kleur zijn een aantal grenswaarden voor orbitaalsnelheid aangegeven. Het "dal" geeft een mogelijke grenswaarde aan. De onverklaarde variantie van soortsamenstelling is berekend door uitvoeren van een RDA (multivariate analyse), de onverklaarde variantie van de andere biotische variabelen met een anova. 


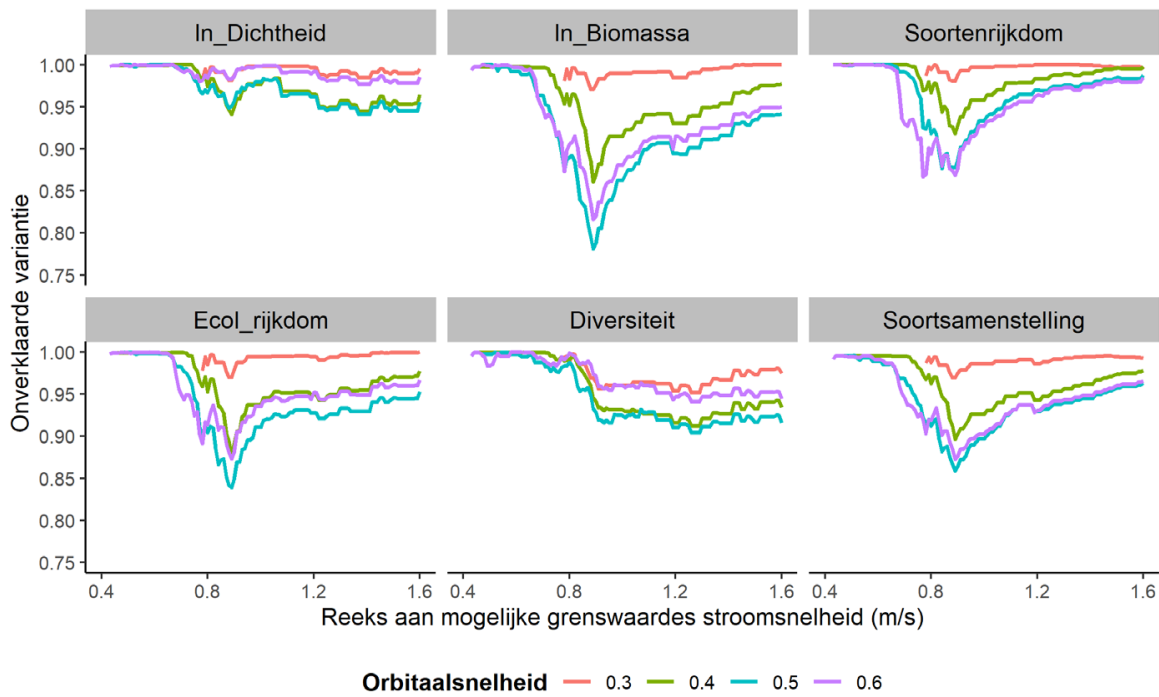

Figur 15 Onverklaarde variantie uit de anova tabel op de y-as met mogelijke grenswaarden voor de stroomsnelheid voor de Amelander Zeegat data. In kleur zijn een aantal grenswaarden voor orbitaalsnelheid aangegeven. Het "dal" geeft een mogelijke grenswaarde aan. De onverklaarde variantie van soortsamenstelling is berekend door uitvoeren van een RDA (multivariate analyse), de onverklaarde variantie van de andere biotische variabelen met een anova.

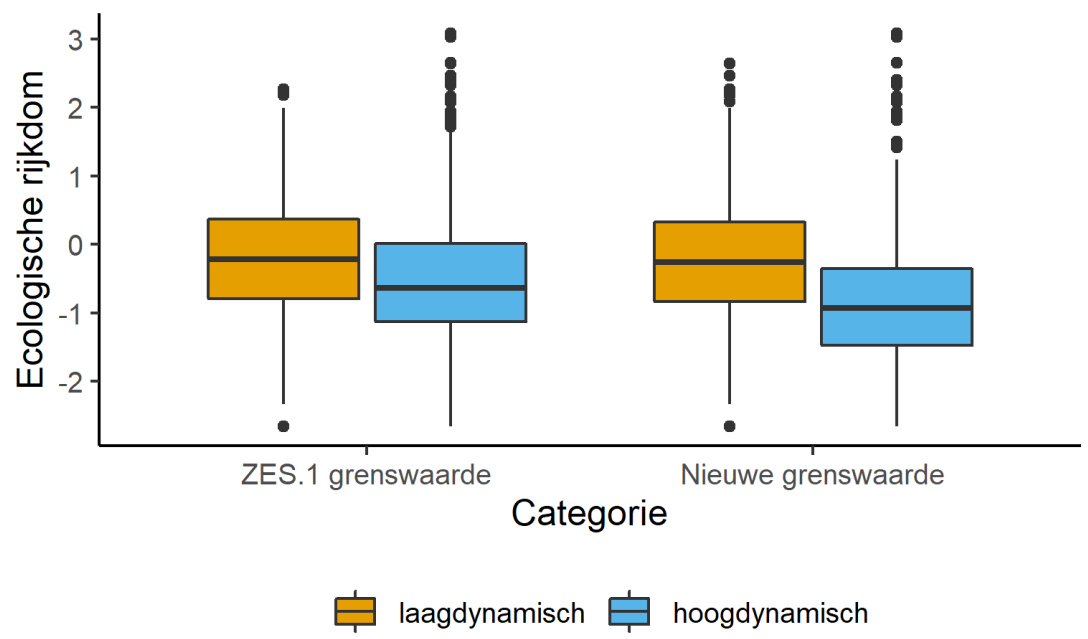

Figuur 16 Ecologische rijkdom uit de SIBES/Waddenmozaïek data voor de combinatie van stroomsnelheid en orbitaalsnelheid op basis van de huidige ZES.1 grenswaarden van 0,8 m/s stroomsnelheid i.c.m. $0,25 \mathrm{~m} / \mathrm{s}$ orbitaalsnelheid (links) en de voorgestelde nieuwe grenswaarden van $0,8 \mathrm{~m} / \mathrm{s}$ stroomsnelheid i.c.m. $0,5 \mathrm{~m} / \mathrm{s}$ orbitaalsnelheid (rechts). De nieuwe grenswaarden resulteren in een groter verschil in ecologische rijkdom tussen de beide groepen. 


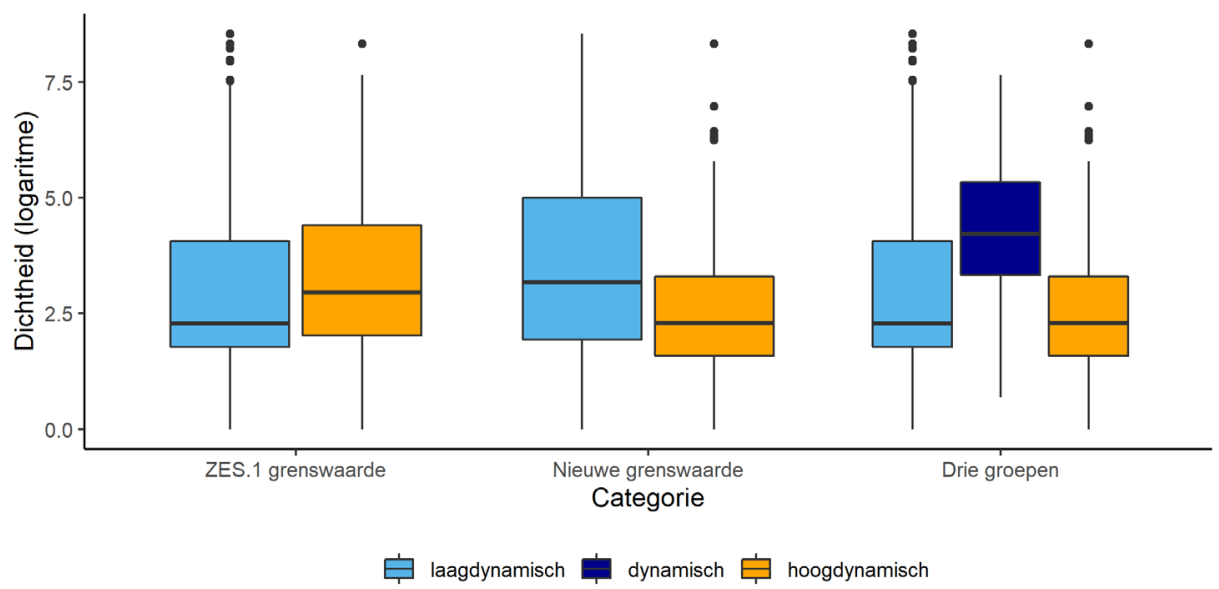

Figuur 17 Dichtheid (logaritme) uit de WOT dataset voor punten uit de Noordzee voor de combinatie van stroomsnelheid en orbitaalsnelheid op basis van de huidige ZES. 1 grenswaarden $0,8 \mathrm{~m} / \mathrm{s}$ stroomsnelheid i.c.m. 0,25 m/s orbitaalsnelheid (links), op basis van nieuwe grenswaarden $0,8 \mathrm{~m} / \mathrm{s}$ stroomsnelheid i.c. $\mathrm{m}$. $0,50 \mathrm{~m} / \mathrm{s}$ orbitaalsnelheid (midden) en op basis van nieuwe grenswaarden $0,8 \mathrm{~m} / \mathrm{s}$ stroomsnelheid i.c.m 0,25 $\mathrm{m} / \mathrm{s}$ én $0,50 \mathrm{~m} / \mathrm{s}$ (rechts). De nieuwe groep met middelhoge dynamiek ( $0,8 \mathrm{~m} / \mathrm{s}$ stroomsnelheid i.c.m. een orbitaalsnelheid tussen $0,25-0,50 \mathrm{~m} / \mathrm{s}$ ) resulteert in een hogere dichtheid.

\subsubsection{Sediment - Slibrijk, fijn zand en grof zand}

Voor het bepalen van de grenswaarde tussen fijn en grof zand is eerst de data geselecteerd met een slibgehalte kleiner dan 25\%. De grenswaarde voor korrelgrootte van de SIBES/Waddenmozaïek data ligt vrij dicht bij de grenswaarde gebruikt in het ZES systeem; 270 i.p.v. $250 \mu \mathrm{m}$, maar de onverklaarde variantie wanneer deze grenswaarde wordt gebruikt is zeer hoog en dus is dit resultaat niet erg overtuigend (Tabel 7, Figuur 18). Voor de WOT data is geen duidelijke grenswaarde gevonden voor het onderscheid tussen fijn en grof zand (Tabel 8).

De grenswaarde om slibarm van slibrijk te onderscheiden komt veel lager te liggen dan de huidige ZES grenswaarde van 25\% voor zowel de SIBES/Waddenmozaïek data als de WOT data, namelijk op respectievelijk $\sim 3 \%$ en $\sim 10 \%$ (Tabel 3, Figuur 18, Figuur 19). Een uitzondering vormt soortsamenstelling van SIBES/Waddenmozaïek waarvoor de grenswaarde op $10 \%$ ligt. Bij de grenswaarde die uit de WOT data komt, moet worden opgemerkt dat de grenswaarde ook hoger kan liggen; het dal voor mogelijke grenswaarden tussen $10-20 \%$ geeft een vergelijkbaar resultaat wat betreft onverklaarde variantie, wanneer we de resultaten van dichtheid en biomassa bekijken (Figuur 19). Om te corrigeren voor het eventuele effect van stromings- en of golfdynamiek, werd de analyse ook uitgevoerd op een subset van de datasets. Wanneer de dataset van SIBES/Waddenmozaïek werd opgesplitst in sublitoraal-laagdynamisch, sublitoraal-hoogdynamisch, litoraal-laag, litoraal-midden en litoraal-hoog, toont de analyse ook een lage grenswaarde om slibrijk van slibarm te onderscheiden (behalve wederom voor soortsamenstelling) (Bijlage 4). Ook de WOT data laat vergelijkbare resultaten zien als bij de analyse over de hele dataset, met uitzondering van de analyse over de selectie van sublitoraal hoogdynamisch; hieruit komt een mogelijke grenswaarde van $\sim 20 \%$ slibgehalte op basis van de biotische variabele dichtheid (Bijlage 4).

De nieuwe grenswaarden voor slibgehalte van 3\% voor de SIBES/Waddenmozaïek data en $10 \%$ voor de WOT data, verklaren beter de biotische indicatoren behalve die voor soortsamenstelling in de SIBES/Waddenmozaïek data. Voor deze biotische variabele werd in de analyse een hogere grenswaarde van 10-13\% slib gevonden (Tabel 10, Tabel 11, Tabel 13). De nieuwe grenswaarde van $3 \%$ slib (Tabel 3) resulteert voor de SIBES/Waddenmozaïek data in een iets lagere gemiddelde ecologische rijkdom voor de categorie fijn zand ten opzichte van slibrijke ecotopen (Figuur 20). 

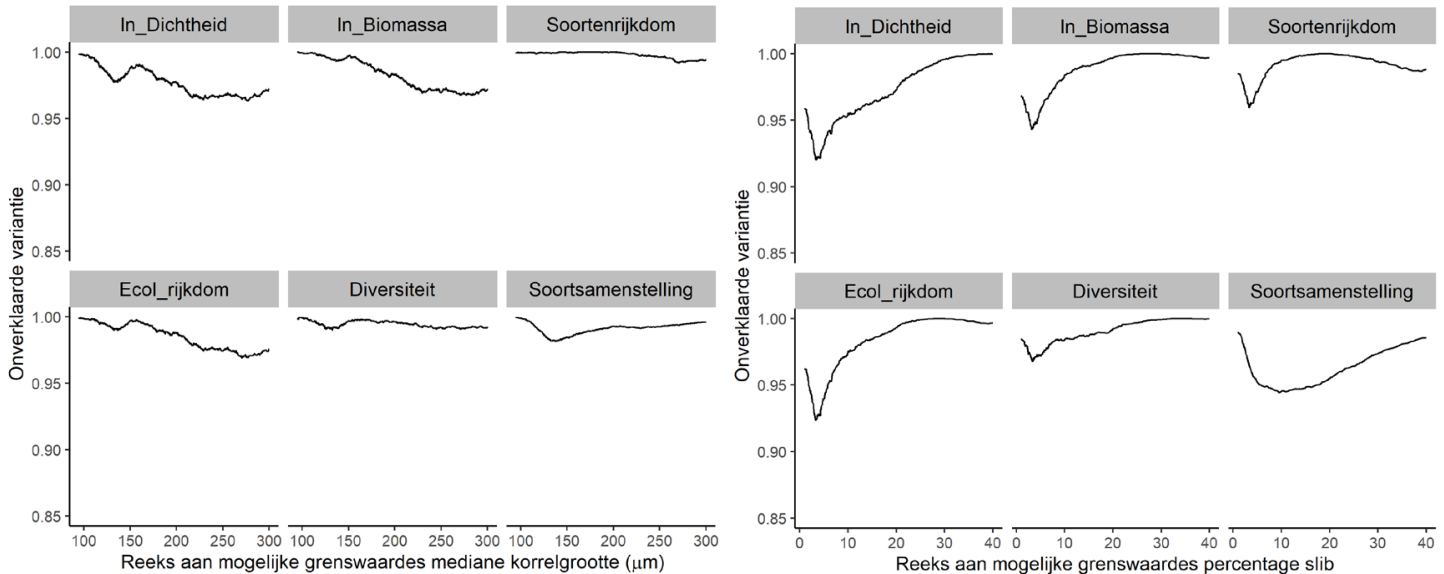

Figuur 18

Onverklaarde variantie op de $y$-as met mogelijke grenswaarden voor de mediane korrelgrootte (links) en slibgehalte (rechts) van de SIBES/Waddenmozaïek dataset. Het "dal" geeft een mogelijke grenswaarde aan. De onverklaarde variantie van soortsamenstelling is berekend door uitvoeren van een RDA (multivariate analyse), de onverklaarde variantie van de andere biotische variabelen met een anova.
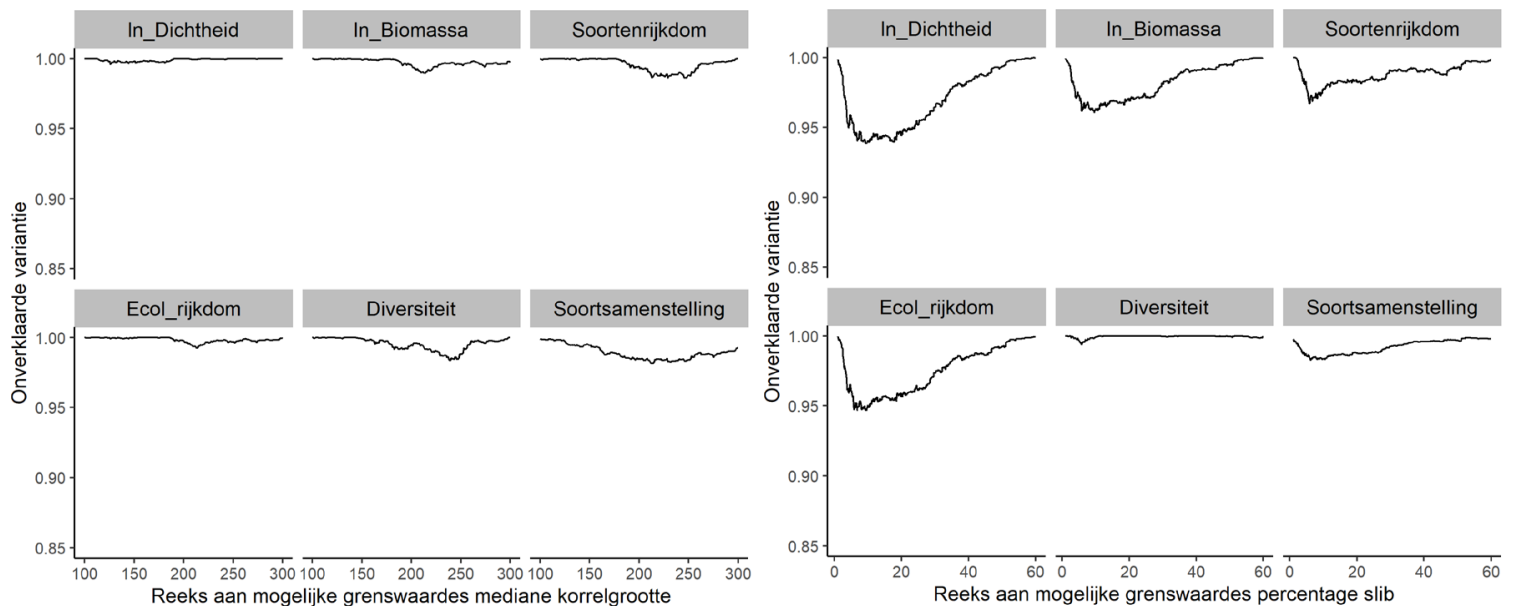

Figur 19 Onverklaarde variantie op de $y$-as met mogelijke grenswaarden voor de mediane korrelgrootte (links) en slibgehalte (rechts) van de WOT dataset. Het "dal" geeft een mogelijke grenswaarde aan. De onverklaarde variantie van soortsamenstelling is berekend door uitvoeren van een RDA (multivariate analyse), de onverklaarde variantie van de andere biotische variabelen met een anova.

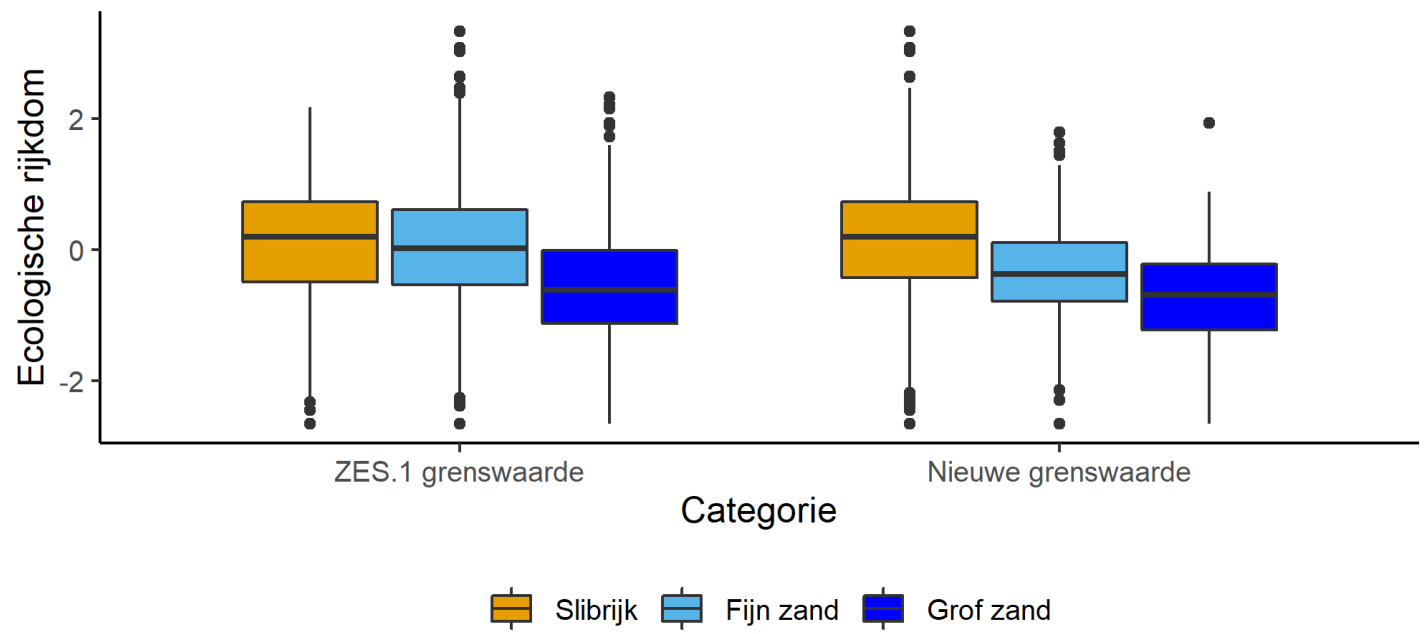

Figur 20 Ecologische rijkdom van de SIBES/Waddenmozaïek data per sedimentcategorie op basis van de huidige ZES.1 grenswaarden 25\% slibgehalte en $250 \mu \mathrm{m}$ mediane korrelgrootte (links) en op basis van de voorgestelde nieuwe grenswaarden 3\% slibgehalte en $250 \mu \mathrm{m}$ korrelgrootte (rechts) De nieuwe grenswaarde voor slibgehalte resulteert in een hogere ecologische rijkdom voor slibrijke ecotopen. 


\subsubsection{Zout - zoutgehalte en variatie}

Voor zowel zoutgehalte als zoutvariatie zijn geen duidelijke grenswaarden gevonden, met uitzondering voor de biotische variabele soortenrijkdom in de WOT dataset, waar een grenswaarde uitkomt voor zoutgehalte van 27 ppt en voor zoutvariatie van 42\% (Tabel 7, Tabel 8, Figuur 21, Figuur 22, Figuur 23, Figuur 24). Deze variabele is echter niet de meest betrouwbare indicator voor deze dataset, zoals beschreven in de methode. Daarom hebben we deze grenswaarde niet verder getest. Aanvullend is nog een analyse uitgevoerd waarbij voor de SIBES/Waddenmozaïek dataset de meetpunten in de Eems-Dollard zijn geselecteerd, omdat in dit gebied een grote variatie in zoutgehalte werd verwacht. Uit deze analyse komt een grenswaarde tussen brak en zout van 28 ppt, met vooral een sterk resultaat voor de biotische variabele dichtheid en diversiteit (Figuur 21). Deze waarde ligt hoger dan in de ZES. 1 bepaalde waarde van 18 ppt om brak van zout water te onderscheiden. Voor zoutvariatie toont deze analyse waardes tussen de 13 en $50 \%$ met vooral een relatief sterk resultaat voor dichtheid gevolgd door diversiteit en soortsamenstelling (resp. 13.1, 14.8 en 38.6, Figuur 23). Echter, er zijn geen SIBES-monsterpunten in de Eems-Dollard waarbij de zoutvariatie hoger was dan $100 \%$, de eerder gesuggereerde grenswaarde voor zoutvariatie. Waarden hoger dan $100 \%$ blijven beperkt tot de Eems rivier (Van Weerdenburg \& Vroom, 2021).
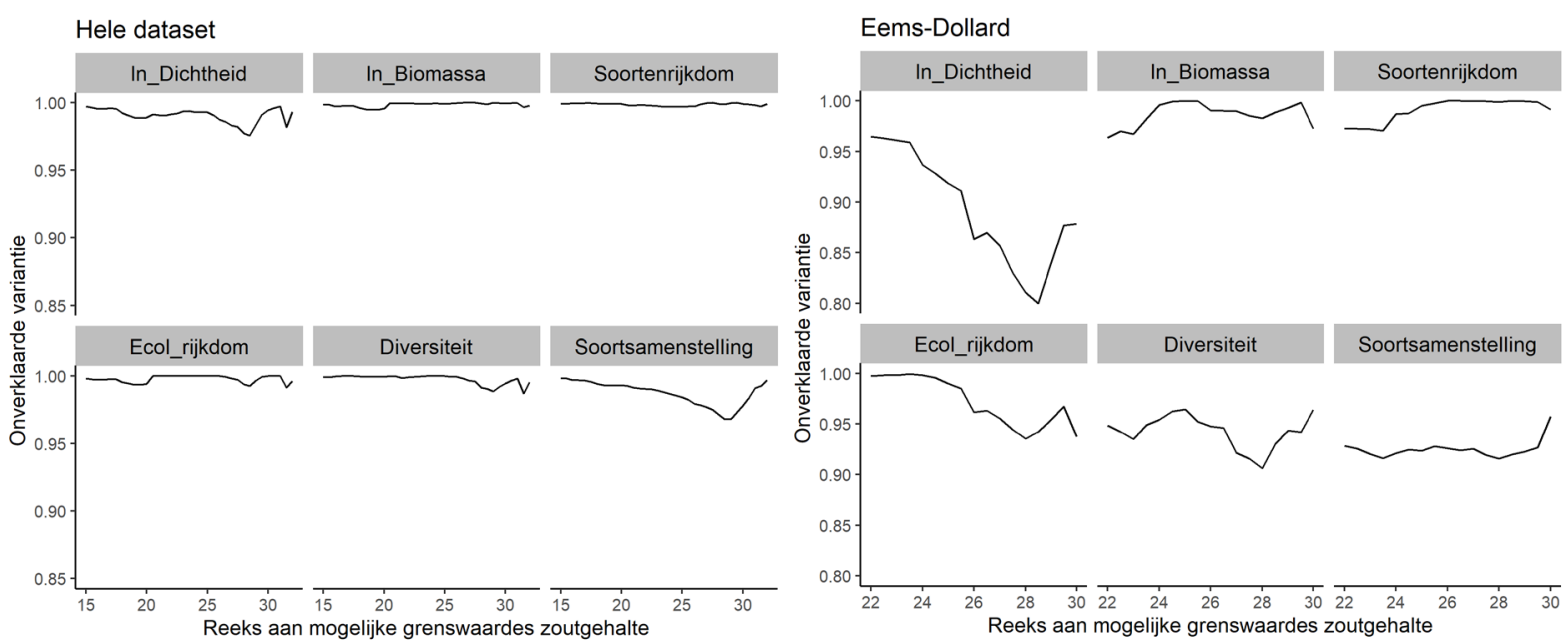

Figur 21 Onverklaarde variantie op de $y$-as met mogelijke grenswaarden voor zoutgehalte voor de hele dataset (links) en zoutgehalte voor meetpunten in de Eems-Dollard (rechts) van de SIBES/Waddenmozaïek dataset. Het "dal" geeft een mogelijke grenswaarde aan. De onverklaarde variantie van soortsamenstelling is berekend door uitvoeren van een RDA (multivariate analyse), de onverklaarde variantie van de andere biotische variabelen met een anova. 


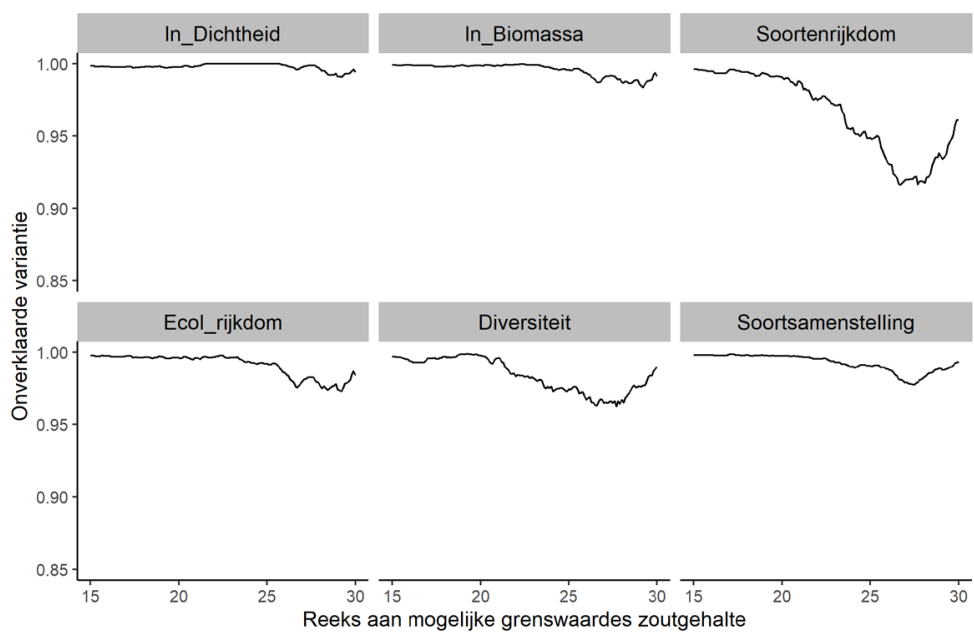

Figur 22 Onverklaarde variantie op de $y$-as met mogelijke grenswaarden voor zoutgehalte van de WOT dataset. Het "dal" geeft een mogelijke grenswaarde aan. De onverklaarde variantie van soortsamenstelling is berekend door uitvoeren van een RDA (multivariate analyse), de onverklaarde variantie van de andere biotische variabelen met een anova.
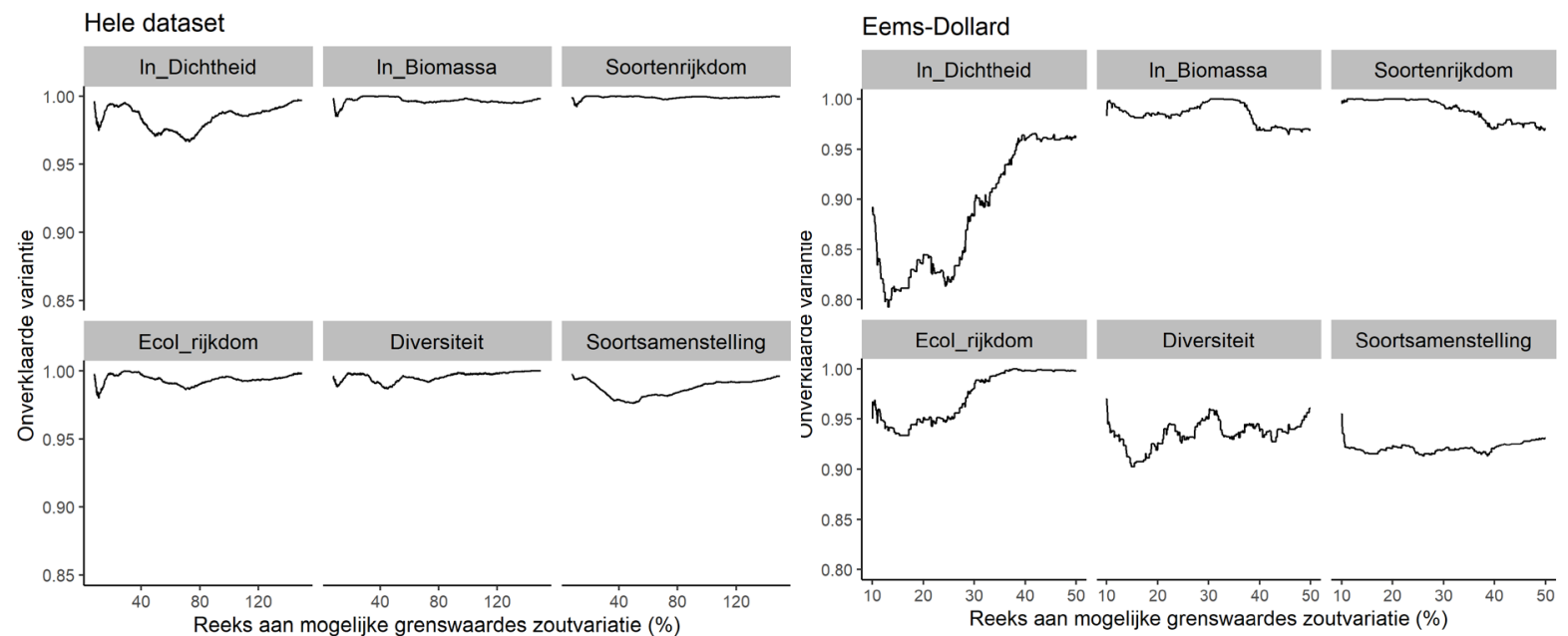

Figuur 23 Onverklaarde variantie op de $y$-as met mogelijke grenswaarden voor zoutvariatie voor de hele dataset (links) en zoutgehalte voor meetpunten in de Eems-Dollard (rechts) van de SIBES/Waddenmozaïek dataset. Het "dal" geeft een mogelijke grenswaarde aan. De onverklaarde variantie van soortsamenstelling is berekend door uitvoeren van een RDA (multivariate analyse), de onverklaarde variantie van de andere biotische variabelen met een anova.

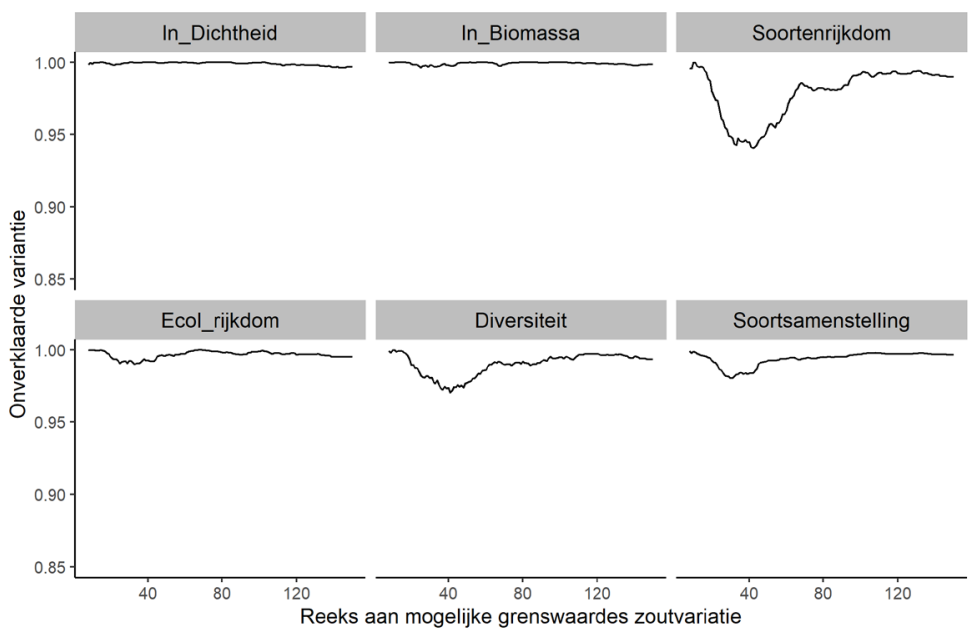

Figur 24 Onverklaarde variantie op de $y$-as met mogelijke grenswaarden voor zoutvariatie van de WOT dataset. Het "dal" geeft een mogelijke grenswaarde aan. De onverklaarde variantie van soortsamenstelling is berekend door uitvoeren van een RDA (multivariate analyse), de onverklaarde variantie van de andere biotische variabelen met een anova. 
Tabel 3

Overzicht gebruikte grenswaarden in de Waddenzee/Noordzee van het ZES.1 en voorstel tot nieuwe grenswaarden.

Abiotische variabelen zijn percentage droogvalduur (droogvalduur in \%), stroomsnelheid $(\mathrm{m} / \mathrm{s})$, orbitaalsnelheid $(\mathrm{m} / \mathrm{s})$, zoutgehalte (Cl-/l), zoutvariatie (\%), korrelgrootte $(\mu \mathrm{m})$ en/of percentage slib (\%). Stroomsnelheid, orbitaalsnelheid en de combinatie zijn voor de SIBES/Waddenmozaïek data getest op de sublitorale data en voor de WOT data zijn in dit overzicht de uitkomsten van de Noordzee-monsterpunten gepresenteerd. Voor de andere biotische variabelen zijn voor de WOT data de Waddenzee-monsterpunten gebruikt. Blauw = ZES.1 grenswaarde bevestigd, Groen = nieuwe grenswaarde verklaart meer variantie dan de oude grens met 1 of meer biotische variabele $(n)$, Oranje = niet mogelijk betrouwbaar te testen. Geen kleur = geen (betrouwbare) grenswaarde gevonden.

\begin{tabular}{|c|c|c|c|c|c|}
\hline Abiotiek & Categorie & ZES. 1 & $\begin{array}{l}\text { SIBES/Wadden- } \\
\text { mozaïek }\end{array}$ & WOT & Amelander Zeegat \\
\hline \multirow{5}{*}{$\begin{array}{l}\text { Droogvalduur } \\
(\%)\end{array}$} & Sublitoraal & $<4 \%$ & & $<4 \%$ & $n v t$ \\
\hline & Litoraal-laag & $4 \%-25 \%$ & $4 \%-25 \%$ & & $n v t$ \\
\hline & $\begin{array}{l}\text { Litoraal- } \\
\text { midden }\end{array}$ & $25 \%-75 \%$ & $25 \%-40 \% *$ & $25 \%-40 \% * *$ & $n v t$ \\
\hline & Litoraal-hoog & $75 \%-85 \%$ & $40 \%-85 \% *$ & $40 \%-85 \% * *$ & $n v t$ \\
\hline & Supralitoraal & $>85 \%$ & $n v t$ & $n v t$ & $n v t$ \\
\hline \multirow[t]{2}{*}{$\begin{array}{l}\text { Stroomsnelheid } \\
(\mathrm{m} / \mathrm{s})\end{array}$} & $\begin{array}{l}\text { Zwakke } \\
\text { stroming }\end{array}$ & $<0,8$ & $<1,0 * *$ & $<0,8$ & $<0,9 * *$ \\
\hline & $\begin{array}{l}\text { Sterke } \\
\text { stroming }\end{array}$ & $>0,8$ & $>1,0 * *$ & $>0,8$ & $>0,9 * *$ \\
\hline \multirow{2}{*}{$\begin{array}{l}\text { Orbitaalsnelheid } \\
(\mathrm{m} / \mathrm{s})\end{array}$} & Zwakke golven & $<0,25$ & & $<0,25$ & $<0,50 *$ \\
\hline & Sterke golven & $>0,25$ & & $>0,25$ & $>0,50 *$ \\
\hline \multirow[t]{3}{*}{$\begin{array}{l}\text { Combinatie } \\
(\mathrm{m} / \mathrm{s})\end{array}$} & $\begin{array}{l}\text { Laag- } \\
\text { dynamisch }\end{array}$ & $\begin{array}{l}\text { Stroomsnelheid }<0,8 \& \\
\text { orbitaalsnelheid }<0,25\end{array}$ & $\begin{array}{l}\text { Stroomsnelheid }<1,0 \& \\
\text { orbitaalsnelheid }<0,5^{* *}\end{array}$ & $\begin{array}{l}\text { Stroomsnelheid }<0,8 \& \\
\text { orbitaalsnelheid }<0,25^{* *}\end{array}$ & $\begin{array}{l}\text { Stroomsnelheid }<0,9 \& \\
\text { orbitaalsnelheid }<0,5^{* *}\end{array}$ \\
\hline & $\begin{array}{l}\text { Middel- } \\
\text { dynamisch }\end{array}$ & - & - & $\begin{array}{l}\text { Stroomsnelheid }<0,8 \& \\
\text { orbitaalsnelheid tussen } \\
0,25 \text { en } 0,50 * *\end{array}$ & \\
\hline & $\begin{array}{l}\text { Hoog- } \\
\text { dynamisch }\end{array}$ & $\begin{array}{l}\text { Stroomsnelheid }>0,8 \text { of } \\
\text { orbitaalsnelheid }>0,25\end{array}$ & $\begin{array}{l}\text { Stroomsnelheid }>1,0 \text { of } \\
\text { orbitaalsnelheid }>0,5^{* *}\end{array}$ & $\begin{array}{l}\text { Stroomsnelheid }>0,8 \text { of } \\
\text { orbitaalsnelheid }>0,25^{* *}\end{array}$ & $\begin{array}{l}\text { Stroomsnelheid }<0,9 \& \\
\text { orbitaalsnelheid }<0,5^{* *}\end{array}$ \\
\hline \multirow[t]{2}{*}{$\begin{array}{l}\text { Zoutgehalte } \\
\left(\mathrm{Cl}^{-} / \mathrm{I}\right)\end{array}$} & Brak & $0,5-18$ & $<28 * * *$ & $<27 * * *$ & $n v t$ \\
\hline & Zout & $>18$ & $>28 * * *$ & $>27 * * *$ & $n v t$ \\
\hline \multirow{2}{*}{$\begin{array}{l}\text { Zoutvariatie } \\
(\%)\end{array}$} & Niet-variabel & $<100$ & & $<42 * * *$ & $n v t$ \\
\hline & Variabel & $>100$ & & $>42 * * *$ & $n v t$ \\
\hline \multirow[t]{3}{*}{ Sediment } & Slibrijk & $>25 \%$ slib & $>3 \%$ slib** & $>10 \%$ slib* & $n v t$ \\
\hline & Fijn zand & $<25 \%$ slib $\&<250 \mu \mathrm{m}$ & $\begin{array}{l}<3 \% \text { slib } \&<250 \\
\mu \mathrm{m}^{* *}\end{array}$ & & $n v t$ \\
\hline & Grof zand & $<25 \%$ slib \& $>250 \mu \mathrm{m}$ & $\begin{array}{l}<3 \% \text { slib } \&>250 \\
\mu \mathrm{m}^{* *}\end{array}$ & & $n v t$ \\
\hline
\end{tabular}

*Grenswaarde verbetering voor alle geteste biotische variabelen, ** Grenswaarde verbetering voor 1 of 2 geteste biotische variabelen, ***

Grenswaarde niet getest, $n v t=$ niet van toepassing, de abiotische variabele is niet getest met de betreffende dataset 


\section{$5 \quad$ Conclusies en aanbevelingen}

\subsection{Conclusie en discussie}

Het doel van deze rapportage was het valideren van de klassegrenzen in het Zoute wateren EcotopenStelsel aan de hand van bodemdiergegevens. Validatie van de klassegrenzen voor droogvalduur, stroomsnelheid, orbitaalsnelheid, zoutgehalte en -variatie en sedimentsamenstelling zijn uitgevoerd met behulp van drie verschillende datasets uit het jaar 2019.

Uit de analyse van de droogvalduur bleek dat met name de klassegrens tussen litoraal-midden en litoraal-hoog beter verlegd kan worden; een grenswaarde van 40\% droogvalduur verklaart in de meeste analyses meer van de variantie in bodemdiergegevens dan de oude grenswaarde van $75 \%$ droogvalduur. Het verleggen van deze grens betekent ook dat het totale oppervlakte van de verschillende ecotopen verandert. In de Waddenzee wordt het oppervlakte van het ecotoop litoraalmidden kleiner en het oppervlakte van het ecotoop litoraal-hoog groter. Op de kaart met de mogelijk nieuwe klassegrenzen is te zien dat ook met de nieuwe droogvalduurgrenzen het aandeel litoraalmidden nog steeds vrij groot is, vergeleken met hoe het was (Figuur 25). Een grote verbetering is te vinden voor het ecotoop litoraal-hoog. Dit was in de oude situatie een dunne strook die tegen het supralitoraal aan lag, nu geeft deze een duidelijke verdeling voor bijvoorbeeld de hooggelegen platen rond Griend, het wantij onder Schiermonnikoog en de Dollard.

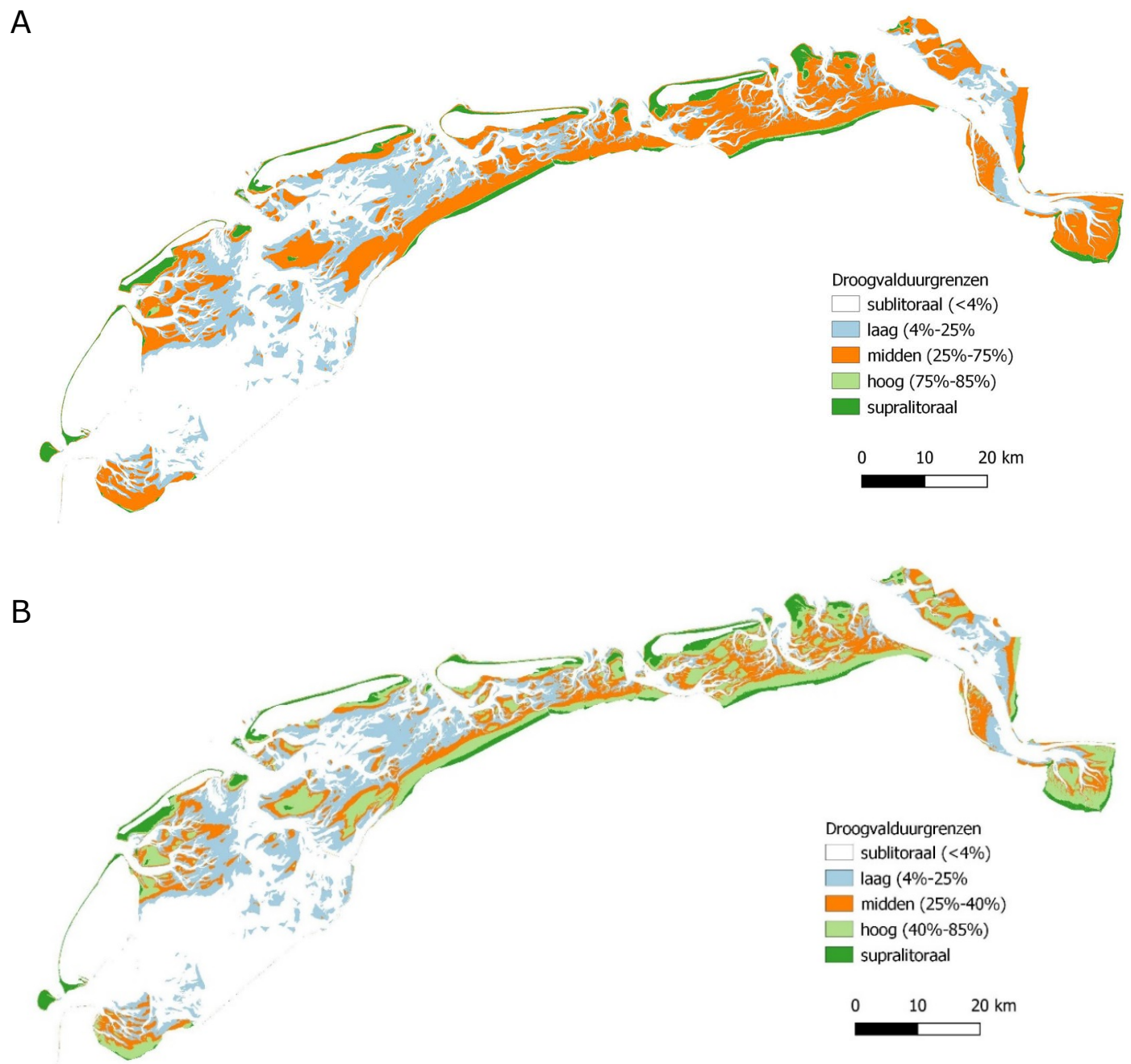

Figuur $25 \quad$ Kaart van de Waddenzee met oude $(A)$ en de mogelijk nieuwe $(B)$ klassegrenzen voor droogvalduur. 
Stroomsnelheid (al dan niet in combinatie met orbitaalsnelheid) wordt in het ZES.1 gebruikt om laagdynamische van hoogdynamische ecotopen te onderscheiden in het sublitorale deel van de Waddenzee. Analyses van de verschillende datasets suggereerden iets verschillende grenswaarden per dataset: $0,8 \mathrm{~m} / \mathrm{s}$ (WOT; dezelfde waarde als in het ZES.1), 0,9 m/s (Amelander Zeegat) en 1,0 m/s (SIBES/Waddenmozaïek) om zwakke van sterke stroming te onderscheiden. Een hogere grenswaarde van $0,95-1,10 \mathrm{~m} / \mathrm{s}$ voor stroomsnelheid werd ook gevonden in de validatiestudie van het ecotopenstelsel voor de Westerschelde (Ysebaert et al., 2016). Desondanks stellen wij voor deze grenswaarde niet te verleggen; uit alle analyses blijkt dat de grenswaarde op of relatief dichtbij de al bestaande grenswaarde ligt.

Voor het onderscheid tussen zwakke en sterke golven (orbitaalsnelheid) zijn grenswaarden verschillend per dataset; geen duidelijke grenswaarde (SIBES-Waddenmozaïek), een grenswaarde van $0,25 \mathrm{~m} / \mathrm{s}$ (WOT; dezelfde waarde als in het ZES.1) en een grenswaarde van $0,5 \mathrm{~m} / \mathrm{s}$ in de buitenwateren van het Amelander Zeegat. De combinatie-analyse van stroom- en orbitaalsnelheid toont vergelijkbare waardes, alhoewel nu bij alle datasets de waarde van $0,5 \mathrm{~m} / \mathrm{s}$ voor orbitaalsnelheid naar boven komt. Met name in de WOT-dataset en voor de buitenwateren lijkt een oplossing waarbij er drie klassegrenzen voor dynamiek gebruikt gaan worden een mogelijkheid: laagdynamisch (orbitaalsnelheid $<0,25 \mathrm{~m} / \mathrm{s}$ en stroomsnelheid $<0,8 \mathrm{~m} / \mathrm{s}$ ), middel-dynamisch (orbitaalsnelheid tussen $0,25-0,5 \mathrm{~m} / \mathrm{s}$ en stroomsnelheid $<0,8 \mathrm{~m} / \mathrm{s}$ ) en hoog-dynamisch (orbitaalsnelheid $>0,5 \mathrm{~m} / \mathrm{s}$ of stroomsnelheid $>0,8 \mathrm{~m} / \mathrm{s}$ ). Op deze manier is er zowel een goede indeling voor dynamiek in de buitenwateren als in de Waddenzee zelf die grotendeels laag-dynamisch is. Deze indeling verklaarde in de WOT-dataset de meeste variantie voor de biotische variabele dichtheid.

De analyse voor de klassegrenzen in sedimenttypen laat variatie zien tussen de twee geteste datasets, en beide suggereren een lagere grenswaarde dan de ZES.1 grenswaarde van 25\% slib om slibrijk van slibarm te onderscheiden. Voor de SIBES/Waddenmozaïek data en de WOT data namelijk op resp. $\sim 3 \%$ en $\sim 10-20 \%$ (met uitzondering van soortsamenstelling van SIBES/Waddenmozaïek waarvoor de grenswaarde op $10 \%$ ligt). Voor de WOT dataset geldt dat er een breed dal is voor grenswaarden liggend tussen de 10-20\%, die voor dichtheid en biomassa een lage onverklaarde variantie geven. Omdat dynamiek van invloed is op het slibgehalte, zijn aanvullende analyses gedaan waarbij er binnen het litoraal en de dynamiekklasses binnen het sublitoraal nog eens apart gekeken is naar mogelijke grenswaarden. Uit deze analyses kwamen geen grote verschillen met de analyse over de hele dataset, met uitzondering van de analyse over een selectie van sublitoraal hoogdynamisch uit de WOT dataset; hieruit komt een mogelijke grenswaarde van 20\% slibgehalte om slibarm van slibrijk te onderscheiden.

Het slibgehalte in de Waddenzee kent een ruimtelijke segregatie tussen zandige geulen en slibrijke platen. Een analyse van de SIBES sedimentgegevens door Herman et al. (2018) liet zien dat ook in de intergetijdegebieden het slibgehalte een bimodale verdeling kent; het slibgehalte is ofwel slibrijk (bandbreedte $20-50 \%$, modus 35\% slib) ofwel slibarm (bandbreedte $2-7 \%$, modus $4.5 \%$ slib). Deze verdeling werd ook gevonden in de data van de Sedimentatlas uit 1990 wat aangeeft dat de bimodale verdeling van de slibgehaltes relatief stabiel is gebleven over de afgelopen 25 jaar (Colina Alonso, 2020). Ook in de SIBES dataset van 2019 is de bimodale verdeling aanwezig, maar niet in de sublitorale Waddenmozaïek-data (Figuur 26). Onze data-analyse op basis van de verspreiding van bodemdieren is toegepast op de gecombineerde dataset voor SIBES/Waddenmozaïek die ook een bimodale verdeling laat zien (Figuur 26, onderste paneel). Het suggereert een verdeling in slibarm vs slibhoudend sediment bij $3 \%$ slibgehalte (getransformeerd geldt $\ln (3)=1,1$ ) en laat ook een tweede grens zien voor slibrijk sediment rond 10-20\% (getransformeerd 2,3-3,0). Dit komt goed overeen met de bimodale verdeling van slib waarbij een waarde van 1,1 (3\% slib) een grens vormt tussen lage slibgehaltes en de eerste piek en een waarde van 2,7 (15\% slib) in het dal ligt voor het begin van de tweede piek. Op basis van bovenstaande analyse is een verdeling in drie klassen voor slibgehalte aan te bevelen: slibarm $<3 \%$, slibhoudend $3 \%-15 \%$ en slibrijk $>15 \%$. 
slibgehalte SIBES 2019

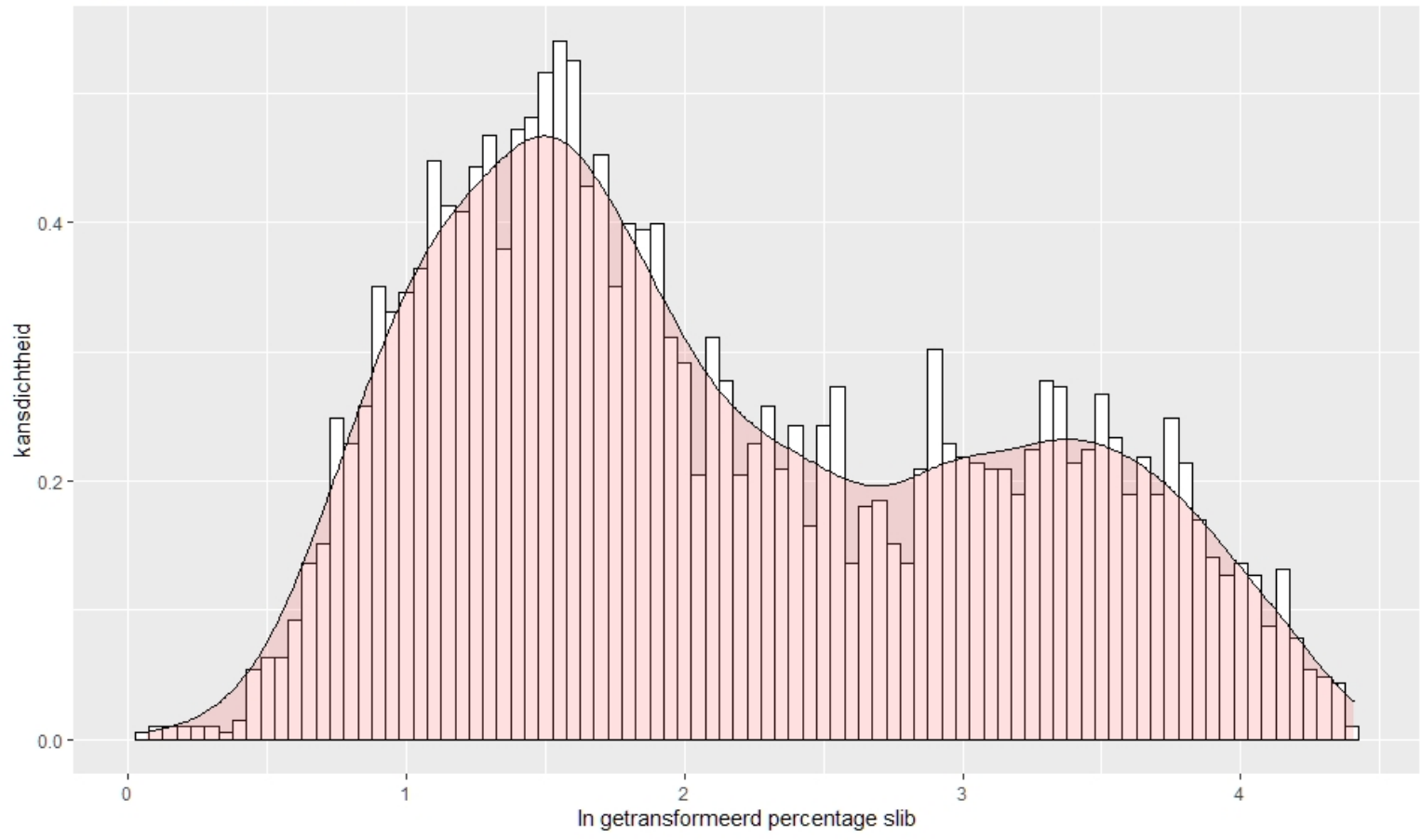

slibgehalte Waddenmozaiek 2019

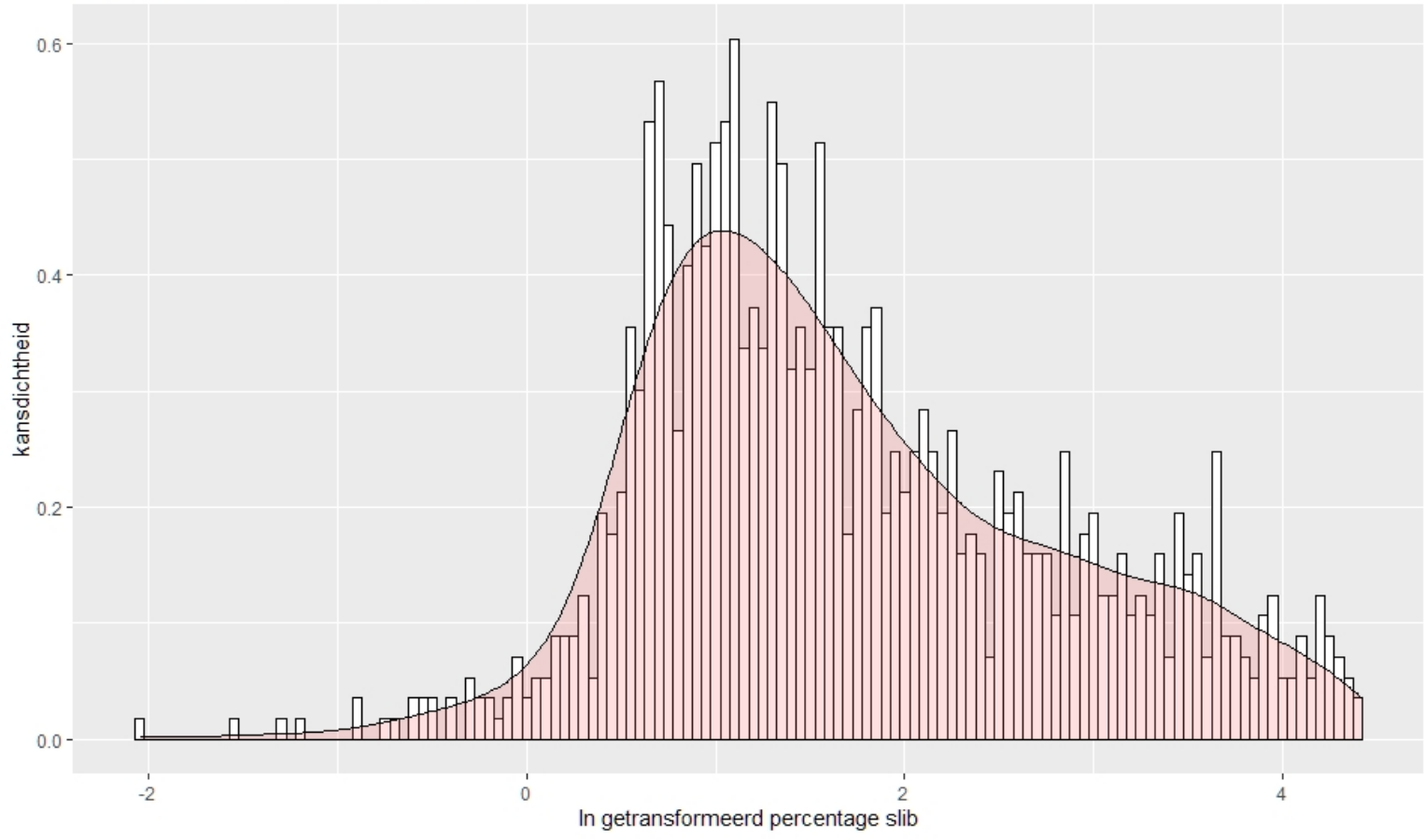




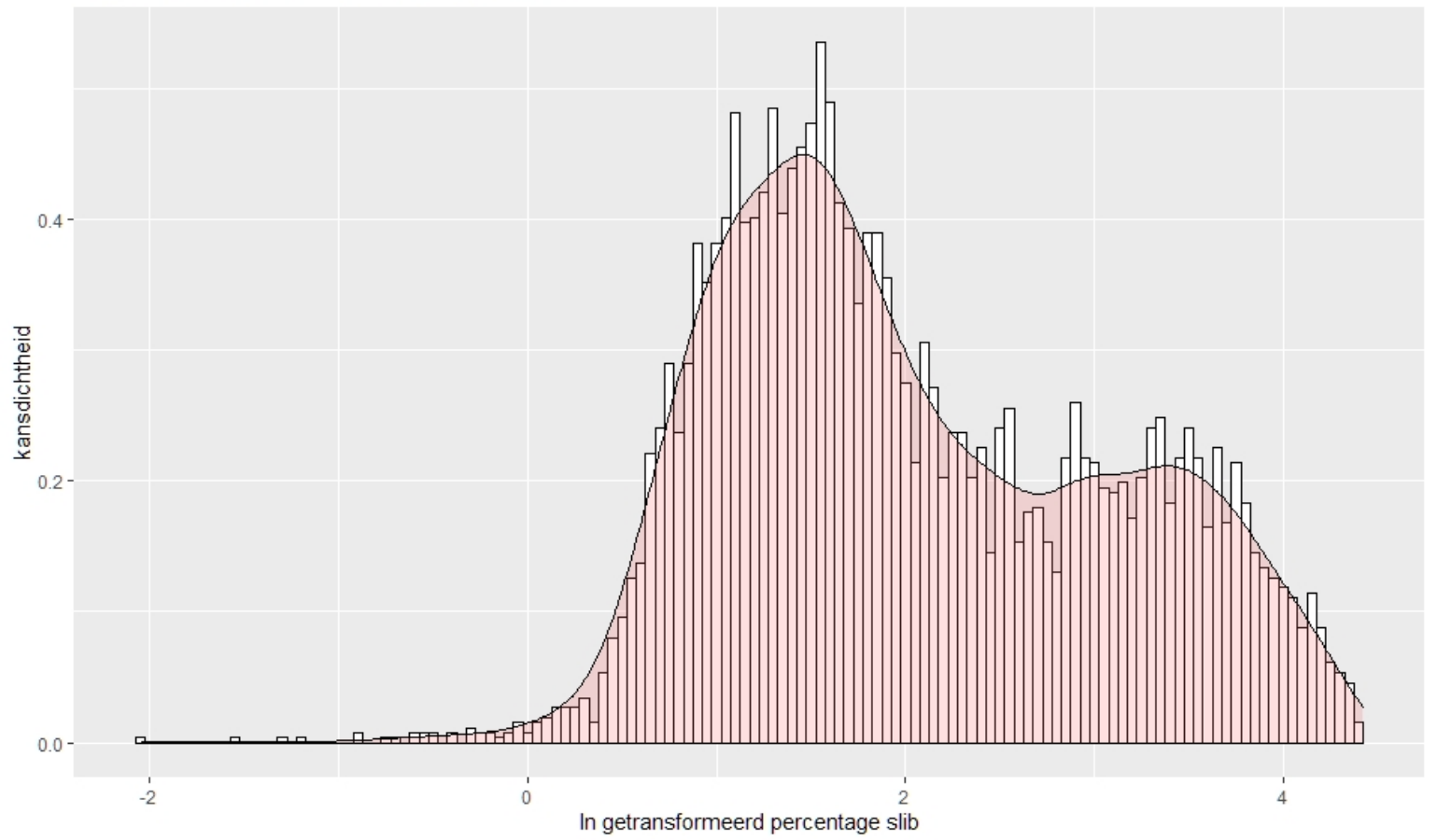

Figur 26 Histogram met kansverdelingsplot van de bimodale verdeling in het slibgehalte in de SIBES-data (bovenste paneel), Waddenmozaiek-data (middelste paneel) en SIBES/Waddenmozaïek-data (onderste paneel).

Mediane korrelgrootte en slibgehalte zijn aan elkaar gerelateerd. De relatie tussen mediane korrelgrootte en slibgehalte in SIBES/Waddenmozaïek-data 2019 is weergegeven in Figuur 27. De blauwe lijn geeft een 'smoother' door de datapunten. Passend bij het slibgehalte van 3\% (onderbroken rode lijn) is de huidige grens in ZES. 1 voor mediane korrelgrootte (D50) van $250 \mu \mathrm{m}$ en passend bij het slibgehalte van 15\% (onderbroken groene lijn) is een mediane korrelgrootte van $125 \mu \mathrm{m}$. Een aanbeveling is om ecotopen alleen nog op basis van slibgehalte te onderscheiden waarbij de drie sedimentklassen in het ecotopenstelsel kunnen worden beschreven als slibarm grof zand $(<3 \%$ slib \& $>250 \mu \mathrm{m}$ D50), slibhoudend fijn zand (3\%-15\% slib \& 125-250 $\mu \mathrm{m}$ D50) en slibrijk zeer fijn zand ( $>15 \%$ slib \& $<125 \mu \mathrm{m}$ D 50 ).

mediane korrelgrootte vs slibgehalte SIBES+Waddenmozaiek 2019

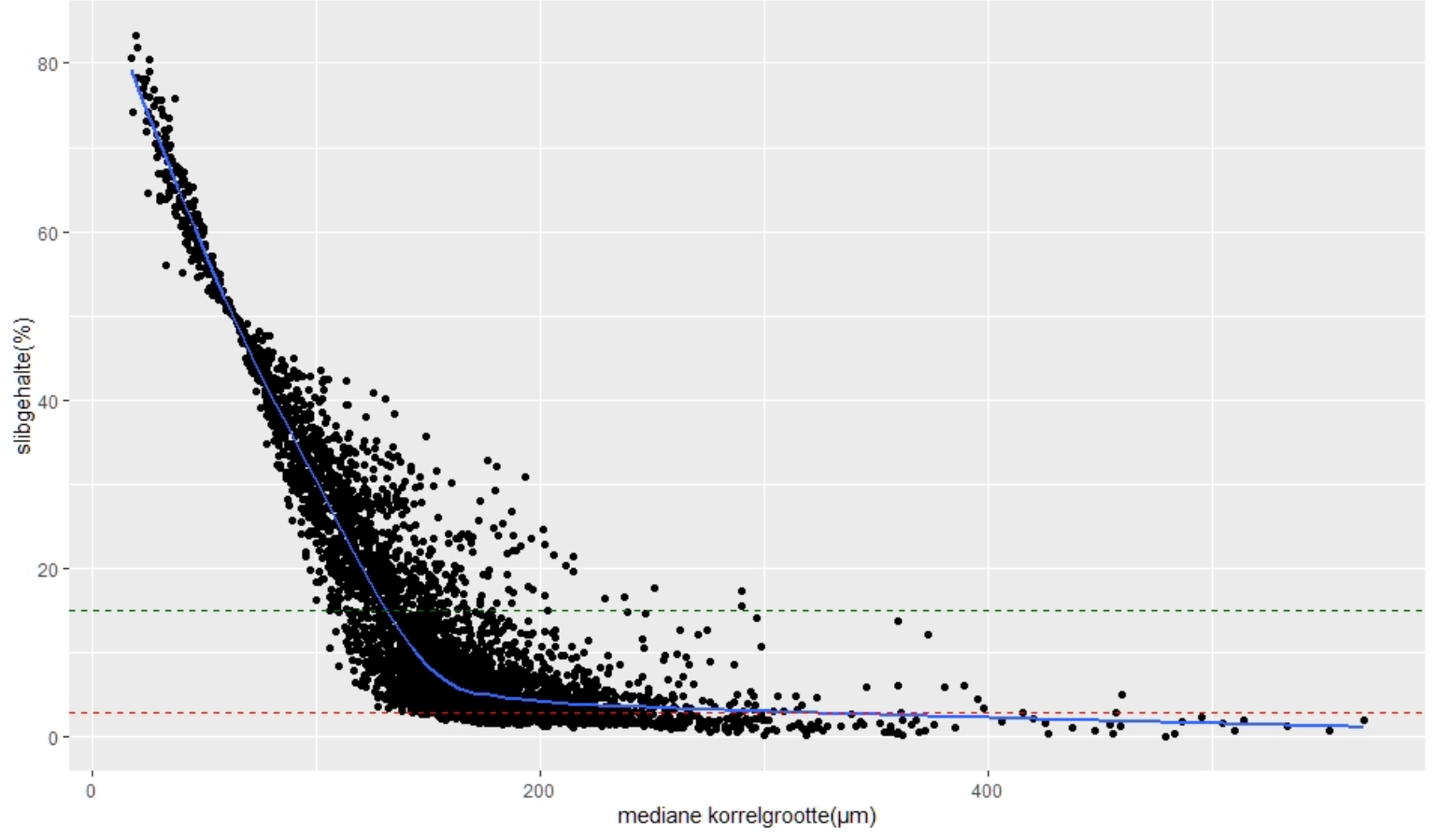

Figuur 27 Relatie tussen mediane korrelgrootte en slibgehalte in de SIBES/Waddenmozaïek-data 2019. 
Voor zoutgehalte en zoutvariatie is geen duidelijke grenswaarde gevonden, met uitzondering van soortenrijkdom in de WOT dataset die een grenswaarde voor zoutgehalte van 27 ppt en voor zoutvariatie van $42 \%$ toont. Soortenrijkdom uit de WOT dataset is echter een minder betrouwbare biotische variabele, vanwege de vele verschillende manieren van bemonsteren die het aantal gevonden soorten per monster kunnen beïnvloeden, zoals beschreven in de methode. Het is verrassend dat er geen duidelijke grenswaarde gevonden is voor zoutgehalte en -variatie. Een mogelijke reden is dat de meetpunten met een brak of variabel karakter wegvallen op het geheel van overwegend zoute meetpunten in de Waddenzee. Om deze reden is er aanvullend een analyse uitgevoerd waarbij voor de SIBES/Waddenmozaïek dataset alleen de meetpunten in de Eems-Dollard zijn geselecteerd, omdat in dit estuariene gebied een meer gelijkwaardige verdeling tussen brak en zout is te vinden. Uit deze analyse komt een grenswaarde die hoger ligt dan de ZES.1 grenswaarde om brak van zout te onderscheiden; 28 ppt ten opzichte van de ZES.1 grenswaarde van 18 ppt. Voor zoutvariatie is deze analyse niet te vergelijken met de voorgestelde ZES.1 grenswaarde, omdat er in de Eems-Dollard geen monsterpunten zijn waarbij de zoutvariatie hoger is dan $100 \%$, de eerder gesuggereerde grenswaarde voor zoutvariatie voor ZES.1. Vanwege de niet eenduidige resultaten, zijn voor zoutgehalte en -variatie aanvullende analyses gewenst.

\section{Opmerkingen omtrent de gebruikte methode}

Een aantal details van de gebruikte datasets en methode lichten we hieronder nog kort toe. Zo verschillen de datasets in de methodes die gebruikt zijn voor de bemonstering. Het Kustgenese 2.0 Amelander Zeegat programma zeeft over een maaswijdte van 0,5 mm, SIBES/Waddenmozaïek zeeft over een maaswijdte van $1 \mathrm{~mm}$ terwijl het WOT programma zeeft over een maaswijdte van $5 \mathrm{~mm}$. Het bemonsterde oppervlakte van Amelander Zeegat data is 0,078 $\mathrm{m}^{2}$, bij SIBES/Waddenmozaiek 0,0173 of $0,0177 \mathrm{~m}^{2}$ en bij WOT is het merendeel $0,42 \mathrm{~m}^{2}$. Hierdoor bemonstert het WOT programma vooral schelpdieren en grotere epifauna terwijl Amelander Zeegat en SIBES/Waddenmozaïek ook de veel kleinere organismen bemonsteren. Er bestaan dus twee complementaire methodes waarbij de ene methode alle bodemdieren bemonsterd van een klein bemonsterd oppervlakte en de andere methode schelpdieren, krabben, garnalen en zeesterren bemonsterd van een groot bemonsterd oppervlakte. Door de verschillende bemonsteringstechnieken kunnen hierdoor verschillen uit de analyses komen. Opvallend genoeg leverden beide datasets juist redelijk vergelijkbare resultaten op wat betreft klassegrenzen, met name voor droogvalduur en stroomsnelheid.

Voor de analyse zijn verschillende rasters van abiotiek gekoppeld aan bodemdiergegevens. De gebruikte rasters verschillen in fijnheid; van 20x20 meter voor droogvalduur tot 100x100 m voor bijvoorbeeld stroomsnelheid. Hierdoor kunnen er op dynamische plekken mogelijk mismatches zijn wat betreft abiotiek en bijbehorende bodemdieren. Daarnaast kan ook het jaar van inwinning van bodemhoogte (2013-2019) met name in de dynamische delen van de Waddenzee voor een mismatch zorgen.

\subsection{Aanbevelingen voor aanpassing ZES.1}

De volgende aanbevelingen zijn geformuleerd door het meenemen van zowel de uitkomsten van de hierboven beschreven en bediscussieerde resultaten als het praktisch gebruik van het ecotopenstelsel;

- $\quad$ Een nieuwe grenswaarde tussen litoraal-midden en litoraal-hoog van $40 \%$ i.p.v. $75 \%$ droogvalduur en behoud van andere grenswaarden voor droogvalduur (4\%, $25 \%$ en $85 \%)$.

- Handhaven van de grenswaarde van 0,8 m/s voor stroomsnelheid om zwakke van sterke stroming te onderscheiden in het sublitoraal.

- Een extra dynamiekklasse invoeren voor de orbitaalsnelheid in het sublitoraal leidend tot twee grenswaarden van $0,25 \mathrm{~m} / \mathrm{s}$ en $0,5 \mathrm{~m} / \mathrm{s}$. De combinatie van stroomsnelheid en orbitaalsnelheid leidt tot drie klassen: laag-dynamisch (orbitaalsnelheid $<0,25 \mathrm{~m} / \mathrm{s}$ en stroomsnelheid $<0,8 \mathrm{~m} / \mathrm{s}$ ), middel-dynamisch (orbitaalsnelheid tussen 0,25-0,5 $\mathrm{m} / \mathrm{s}$ en stroomsnelheid $<0,8 \mathrm{~m} / \mathrm{s}$ ) en hoog-dynamisch (orbitaalsnelheid $>0,5 \mathrm{~m} / \mathrm{s}$ of stroomsnelheid $>0,8 \mathrm{~m} / \mathrm{s}$ ). 
- Drie sedimentklassen onderscheiden op basis van slibgehalte in het bodemsediment die worden beschreven als slibarm grof zand ( $<3 \%$ slib \& $>250 \mu \mathrm{m} \mathrm{D50)}$, slibhoudend fijn zand ( $3 \%-15 \%$ slib \& 125-250 $\mu$ m D50) en slibrijk zeer fijn zand ( $>15 \%$ slib \& $<125 \mu \mathrm{m}$ D50).

- Voorlopig behoud van grenswaarden voor zoutgehalte en zoutvariatie.

\subsection{Aanbevelingen voor vervolgonderzoek ZES.1}

\section{Validatie van diepteklasses voor ondiep en diep sublitoraal}

In deze studie is geen validatie uitgevoerd voor de grenswaarde tussen ondiep sublitoraal en diep sublitoraal. In het ZES. 1 is dit onderscheid gekozen op $5 \mathrm{~m}$ onder GLWS op basis van literatuurstudie over kinderkamers voor juveniele vis (Bouma et al., 2005). Vos \& Wolff (2001) stelden overigens voor een grens vast te stellen op basis van de lichtdoordringing met relevantie voor wieren en kwamen uit op $1 \mathrm{~m}$ onder GLW. Er is geen statistische onderbouwing gegeven van de relatie tussen het voorkomen van juveniele vis en de dieptegrens. Een vervolgonderzoek zou hier aan kunnen bijdragen met gebruik van tientallen jaren aan verspreidingsgegevens van juveniele vis in de Demersal Fish Survey. In deze analyse moet dan ook het zoutgehalte en stromingsdynamiek betrokken worden omdat de verspreiding van vis multivariaat is.

\section{Validatie van bodemdiergegevens uit een overeenkomstig modeljaar}

In deze studie zijn bodemdiergegevens gebruikt van het jaar 2019, terwijl de abiotische gegevens waarmee de ruimtelijke distributie van bodemdieren wordt vergeleken deels van 2017 en deels van 2020 komen. De modelberekeningen zijn gebaseerd op opgetreden waterstanden uit 2017, stroomsnelheden van 23 juni tot 22 juli 2017, orbitaalsnelheid van golven van maart 2020 en zoutgehaltes van 2017. Opgemerkt moet worden dat de onderliggende bathymetrie voor de modelsommen uit zes verschillende jaren komt, namelijk 2013-2019 en dat hiermee een relatief grote onzekerheid wordt geïntroduceerd. Samen met de conclusie dat de verspreiding van levensgemeenschappen tamelijk ongevoelig is voor veranderingen in milieuomstandigheden op de korte termijn (Folmer et al., 2017) is het onwaarschijnlijk dat de keuze voor een ander jaar voor inwinning van bodemdierdata, of de keuze voor een middeling over meerdere jaren, zal leiden tot wezenlijk andere conclusies van deze studie. Echter, een aanbeveling voor vervolgonderzoek is om een vergelijking te maken tussen overeenkomstige jaren, bijvoorbeeld op basis van modelruns voor droogvalduur, stroomsnelheid, orbitaalsnelheid en zoutgehalte voor het jaar 2019, zodat deze aanname getoetst kan worden.

\section{Ligging van monsterpunten in SIBES en WOT}

De datasets van SIBES en WOT bevatten belangrijke jaarlijkse verspreidingsgegevens van bodemdieren in de Waddenzee. Uit onze studie bleek dat er erg weinig SIBES en WOT monsterpunten liggen in het supralitoraal en de pre-pionierzone: de hooggelegen slikken met minder dan $5 \%$ begroeiing van planten. Hierdoor is er mogelijk geen statistische representatie van bodemdieren in deze milieus. Een vervolgonderzoek kan hier aandacht aan besteden.

\section{Karakteristieke soorten per ecotoop}

In de beschrijving van het ZES.1 door Bouma et al., (2005) is uitgebreid aandacht besteed aan de soortensamenstelling van flora en fauna in ecotopen (in Hoofdstuk 6 De ecologische inhoud van ecotopen). In onze studie hebben we karakteristieke soorten bodemdieren bepaald met de oude indeling van de ecotopen, omdat er nog geen beslissingen zijn genomen over de nieuwe indeling. Karakteristieke soorten zouden daarom opnieuw bepaald kunnen worden voor de nieuwe indeling. 


\section{$6 \quad$ Kwaliteitsborging}

Wageningen Marine Research beschikt over een ISO 9001:2015 gecertificeerd kwaliteitsmanagementsysteem. Dit certificaat is geldig tot 15 december 2021. De organisatie is gecertificeerd sinds 27 februari 2001. De certificering is uitgevoerd door DNV GL. 


\section{Literatuur}

Baptist, M J, Van der Wal, J. T., De Groot, A. V, \& Ysebaert, T. J. W. (2016). Ecotopenkaart Waddenzee volgens de ZES. 1 typologie.

Baptist, Martin J, van der Wal, J. T., Folmer, E. O., Gräwe, U., \& Elschot, K. (2019). An ecotope map of the trilateral Wadden Sea. Journal of Sea Research, 152(May), 101761. https://doi.org/10.1016/j.seares.2019.05.003

Boothroyd, J. C., \& Hubbard, D. K. (1975). Genesis of bedforms in mesotidal estuaries. Estuarine Research, Volume II: Geology and Engineering.

Bouma, H., de Jong, D., Twisk, F., \& Wolfstein, K. (2005). Zoute wateren EcotopenStelsel (ZES. 1); voor het in kaart brengen van het potentiële voorkomen van levensgemeenschappen in zoute en brakke rijkswateren. In Rapport RIKZ/2005.024.

Colina Alonso, A. (2020). Evolutie van het bodemslib in de Waddenzee. Delft, Deltares 11205229-001-ZKS0003.

Folmer, E., Dekinga, A., Holthuijsen, S., van der Meer, J., Mosk, D., Piersma, T., \& van der Veer, H. (2017). Species Distribution Models of Intertidal Benthos. Tools for Assessing the Impact of Physical and Morphological Drivers on Benthos and Birds in the Wadden Sea (Issue August).

Herman, P., Van Kessel, T., Vroom, J., Dankers, P., Cleveringa, J., De Vries, B., \& Villars, N. (2018). Mud dynamics in the Wadden Sea: Towards a conceptual model. Delft, Deltares.

Hijmans, R. J. (2020). raster: Geographic Data Analysis and Modeling. R Package Version 3.3-13. Https://CRAN.R-Project.Org/Package=raster.

Kers, A. S., Walburg, L., Bakker, J., Daane, A. H., De Jong, D. J., Schrijver, M., Lievense, P., Dekker, L., \& De Klerk, J. (2013). Dienstbeschrijving Zoute ecotopenkarteringen.

Oksanen, J., Guillaume Blanchet, F., Friendly, M., Kindt, R., Legendre, P., McGlinn, D., Minchin, P. R., O'Hara, R. B., Simpson, G. L., Solymos, P., Henry, M., Stevens, H., Szoecs, E., \& Wagner, H. (2020). vegan: Community Ecology Package. $R$ Package Version 2.5-7. Https://CRAN.RProject. Org/Package = vegan .

Paree, E., Kers, A. S., Jentink, R., Hendriks, J.-R., \& Baptist, M. J. (2020). Toelichting op de zoute ecotopenkaart Waddenzee 2017. Rijkswaterstaat Centrale Informatievoorziening, 1-57.

R Core Team. (2021). R: A Language and Environment for Statistical Computing. R Foundation for Statistical Computing, Vienna. Https://Www.R-Project.Org.

Schellekens, T., \& Verduin, E. (2020). T-1 monitoring Amelander Zeegat.

Shannon, C. E., \& Weaver, W. (1949). The mathematical theory of communication, 1st edn. University of Illinois Press, Urbana, IL.

Troost, K., Van Asch, M., Brummelhuis, E., Van den Ende, D., Van Es, Y., Perdon, K. J., \& Van der Pool, J. (2021). Schelpdierbestanden in de Nederlandse kustzone. Centrum voor Visserijonderzoek CVO rapport: 21.001. https://edepot.wur.nl/538895

Van Weerdenburg, R., \& Vroom, J. (2021). Modelparameters Ecotopenkaart Waddenzee. Delft, Deltares 11206799-003-ZKS-0003.

Van Wesenbeeck, B. K., Holzhauer, H., \& Troost, T. (2010). Using habitat classification systems to assess impacts on ecosystems; Validation of the ZES.1 for the Westerschelde.

Verduin, E. C., \& Leewis, L. (2017). T-nulmeting Benthos buitendelta Amelander Zeegat 2017. Veldrapportage Benthos boxcorer. In Rapport Eurofins Omegam B.V. (Issue versie 02).

Vos, M., \& Wolff, W. J. (2001). Ontwerp-ecotopenstelsel voor de brakke Rijkswateren. In Groningen, Rijksuniversiteit Groningen (RuG), Mariene Biologie.

Ysebaert, T., Craeymeersch, J., \& Van der Wal, D. (2016). De relatie tussen bodemdieren en hydro- en morfodynamiek in het sublitoraal en litoraal van de Westerschelde. 


\section{Verantwoording}

Rapport C093/21

Projectnummer: 4312100127

Dit rapport is met grote zorgvuldigheid tot stand gekomen. De wetenschappelijke kwaliteit is intern getoetst door een collega-onderzoeker en het verantwoordelijk lid van het managementteam van Wageningen Marine Research

Akkoord:

Johan Craeymeersch

Handtekening:

Datum:

\section{Senior onderzoeker}

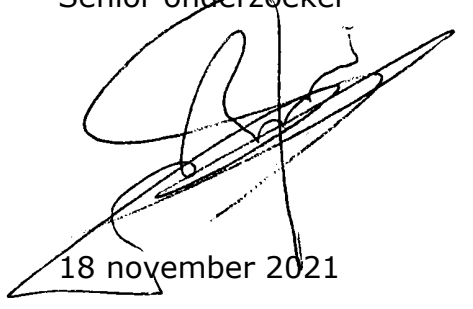

Akkoord:

Dr. J. Asjes

Manager Integratie)

Handtekening:

Datum:

8 november 2021 


\section{Bijlage 1 Data exploratie}

Een data exploratie is uitgevoerd om de relaties tussen biotische indicatoren onderling en abiotische indicatoren onderling in kaart te brengen en te bepalen welke abiotische indicatoren een rol spelen in de verklaring van de biotische indicatoren.

De biotische indicatoren en abiotische indicatoren zijn geplot met scatterplots om mogelijke relaties tussen variabelen te onderzoeken. Om een idee te krijgen van de relatie tussen abiotiek en biotische indicatoren zijn vervolgens (multiple) lineaire en generalized lineair models (GAM) opgesteld met als verklarende variabelen de abiotische variabelen droogvalduur, stroomsnelheid, orbitaalsnelheid, percentage slib en gemiddelde zoutconcentratie en response variabele ecologische rijkdom. Niet alle combinaties van abiotiek zijn gebruikt voor de modellen, maar er is een keuze gemaakt voor het testen van een aantal combinaties waarbij de focus lag op droogvalduur en stroomsnelheid. Modellen zijn met elkaar vergeleken op basis van hun Akaike Information Criterion (AIC). De AIC is een relatieve maat om verschillende modellen met elkaar te kunnen vergelijken waarbij naast de model fit ook de complexiteit (het aantal verklarende variabelen) wordt meegenomen; bij twee vergelijkbare modellen krijgt een model met minder verklarende variabelen een betere score. Het beste model is het model met de laagste AIC waarde, modellen die minstens 2 AIC punten van elkaar verschillen worden gezien als verschillend van elkaar.

\section{Abiotiek}

De relaties tussen abiotische variabelen laten zien dat met name de gemiddelde saliniteit en de variatie in saliniteit, en de mediane korrelgrootte en het percentage slib vrij sterk met elkaar gerelateerd zijn (Figuur 28). Verder is stroomsnelheid vrij sterk negatief gecorreleerd met orbitaalsnelheid en droogvalduur.

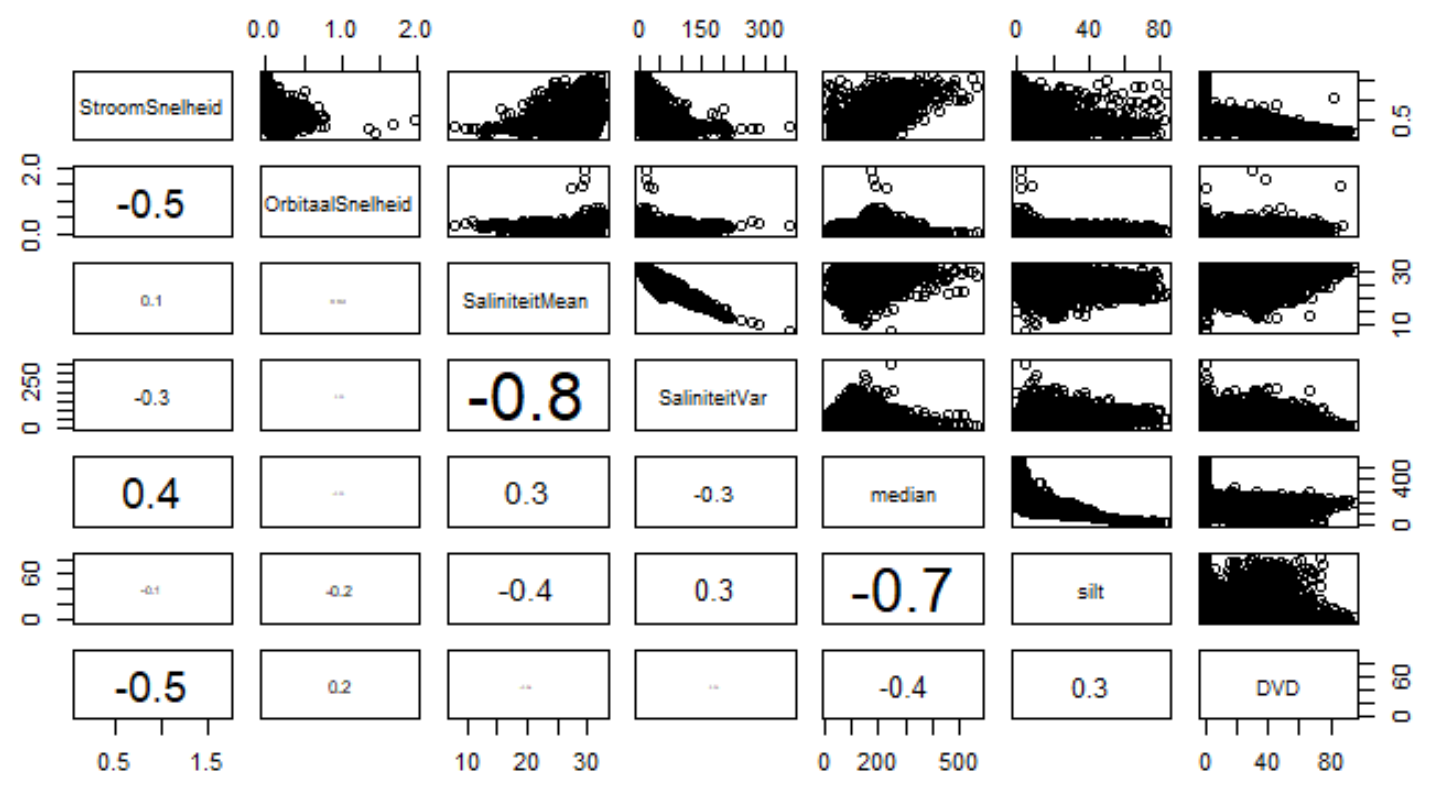

Figuur 28 Relatie tussen abiotische variabelen op de meetposities van de SIBES/Waddenmozaïek data. Stroomsnelheid en orbitaalsnelheid in $\mathrm{m} / \mathrm{s}$, SaliniteitMean = gemiddelde saliniteit in..., SaliniteitVar = variatie in saliniteit in..., median = mediane korrelgrootte $\mu m$, silt $=$ slib in $\%$, DVD $=$ droogvalduur in $\%$.

\section{Biotiek SIBES/Waddenmozaïek}

Biotische indicatoren zijn sterk aan elkaar gecorreleerd. Met name ecologische rijkdom is sterk gecorreleerd aan dichtheid, biomassa en soortenrijkdom. Dit is ook te verwachten omdat ecologische 
rijkdom bestaat uit bovengenoemde variabelen. Diversiteit is veel minder gecorreleerd aan de andere indicatoren. Dit is het geval voor alle biotische datasets; SIBES/Waddenmozaïek (Figuur 29), WOT (Figuur 30) en Amelander Zeegat (Figuur 31). In de WOT dataset is soortenrijkdom minder sterk gecorreleerd aan de andere biotische variabelen. Dit zou te maken kunnen hebben met de methodiek van het WOT programma met veel verschillende monstertechnieken en bijbehorende bemonsterde oppervlaktes die de aantal gevonden soorten per monster kunnen beïnvloeden (zie methode).

De biotische data in de vorm van ecologische rijkdom van de SIBES/Waddenmozaïek dataset wordt het beste verklaard door een multivariaat model waarbij zowel percentage droogvalduur, stroomsnelheid, orbitaalsnelheid, percentage slib en gemiddelde saliniteit zijn meegenomen. Dit model heeft de laagste AIC waarde vergeleken met andere modellen en verklaart ongeveer 32 procent van de variantie in ecologische rijkdom (Tabel 4). Data exploratie toonde dat de biotische data beter verklaard werd door een model waarbij de relatie tussen biotiek en abiotiek niet lineair is. Daarom zijn in Tabel 4 enkel de Generalized Additive Models (GAM) gepresenteerd, dit zijn modellen waarbij de relaties tussen variabelen op een niet-lineaire manier onderzocht kunnen worden. Ter voorbeeld is ecologische rijkdom tegen de variabele percentage droogvalduur en percentage slib geplot (Figuur 32). Wanneer deze variabelen in een apart model worden bekeken, is te zien dat ecologische rijkdom het hoogst is met een percentage droogvalduur van iets boven de $50 \%$ waarna het weer iets afneemt. Ecologische rijkdom lijkt vooral toe te nemen tussen 0 en ongeveer 10 procent slib waarna het fluctueert met percentage slib (Figuur 32). Ook bleek uit de exploratie dat modellen waarin het percentage slib werd meegenomen in plaats van de mediane korrelgrootte meer variantie in ecologische rijkdom verklaarden. Daarom is hieronder enkel het percentage slib meegenomen in de gepresenteerde modellen (Tabel 4). Hetzelfde geldt voor de gemiddelde saliniteit tegenover de variatie in saliniteit. Omdat deze variabelen sterk met elkaar correleren is het niet verstandig allebei de variabelen mee te nemen in hetzelfde model (zie Figuur 28).

De biotische data in de vorm van logaritme van dichtheid van de WOT dataset wordt het beste verklaard door een multivariaat model waarbij zowel percentage droogvalduur, stroomsnelheid, orbitaalsnelheid en percentage slib zijn meegenomen, maar eenzelfde model met gemiddelde saliniteit is vergelijkbaar (Tabel 5). Beide modellen verklaren ongeveer $14 \%$ van de variantie.

Voor het Amelander Zeegat is enkel de stroomsnelheid en orbitaalsnelheid gebruikt. Data exploratie toonde dat de biotische data beter verklaard werd door een model waarbij de relatie tussen biotiek en abiotiek niet lineair is en waar zowel stroomsnelheid als orbitaalsnelheid zijn meegenomen (Tabel 6). 


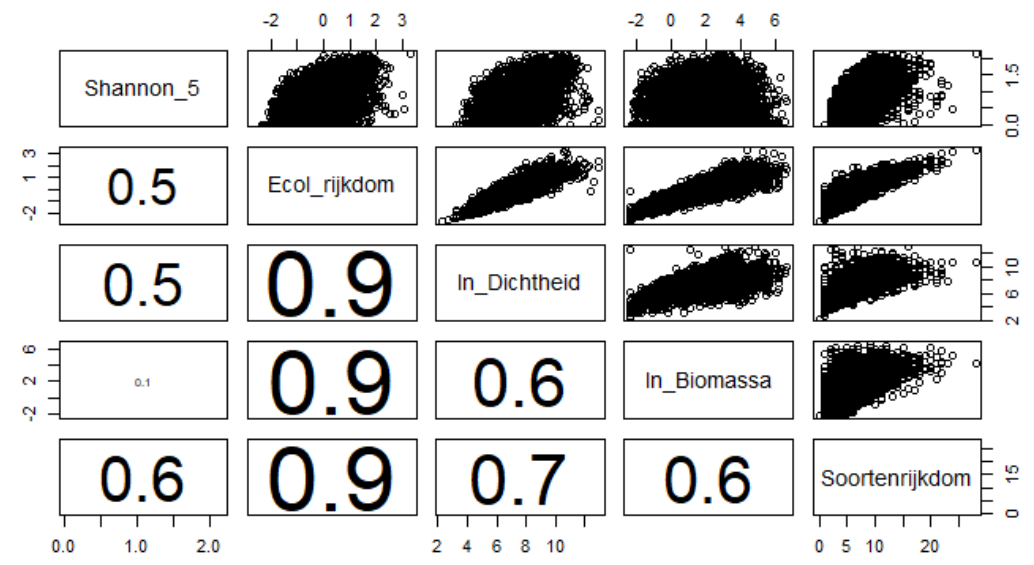

Figur 29 Relatie tussen biotische variabelen van de SIBES/Waddenmozaïek data. Shannon_5 = diversiteit.

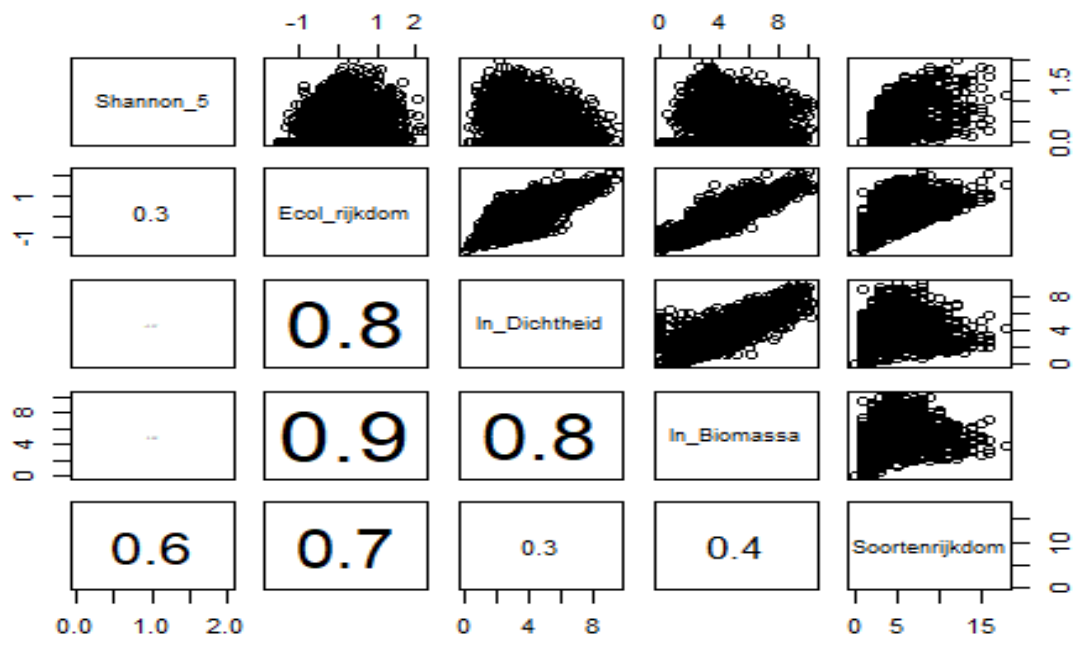

Figur 30 Relatie tussen biotische variabelen van de WOT dataset. Shannon_5 = diversiteit.

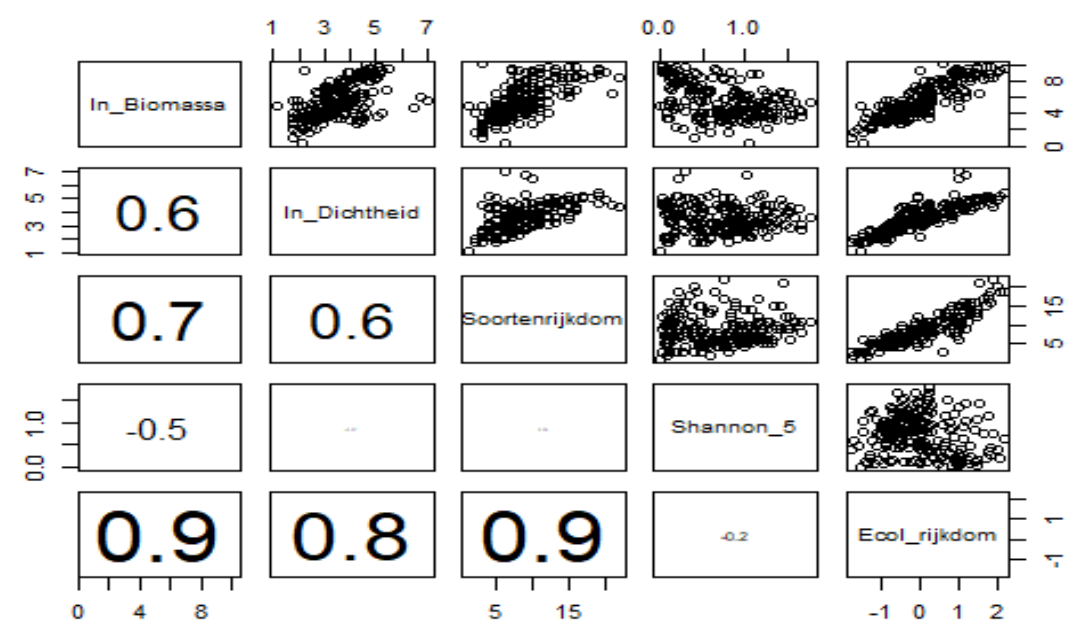

Figuur 31 Relatie tussen biotische variabelen van de Amelander Zeegat dataset. Shannon_5 = diversiteit. 
Tabel 4

Uitkomsten Generalized additive models met response variabele ecologische

rijkdom van SIBES/Waddenmozaïek data en verschillende abiotische factoren

Voor uitvoeren van de analyse zijn alle punten waar abiotische waardes misten verwijderd. Modellen zijn geordend van laagste (beste model) naar hoogste (slechtste model) AIC. DVD = percentage droogvalduur

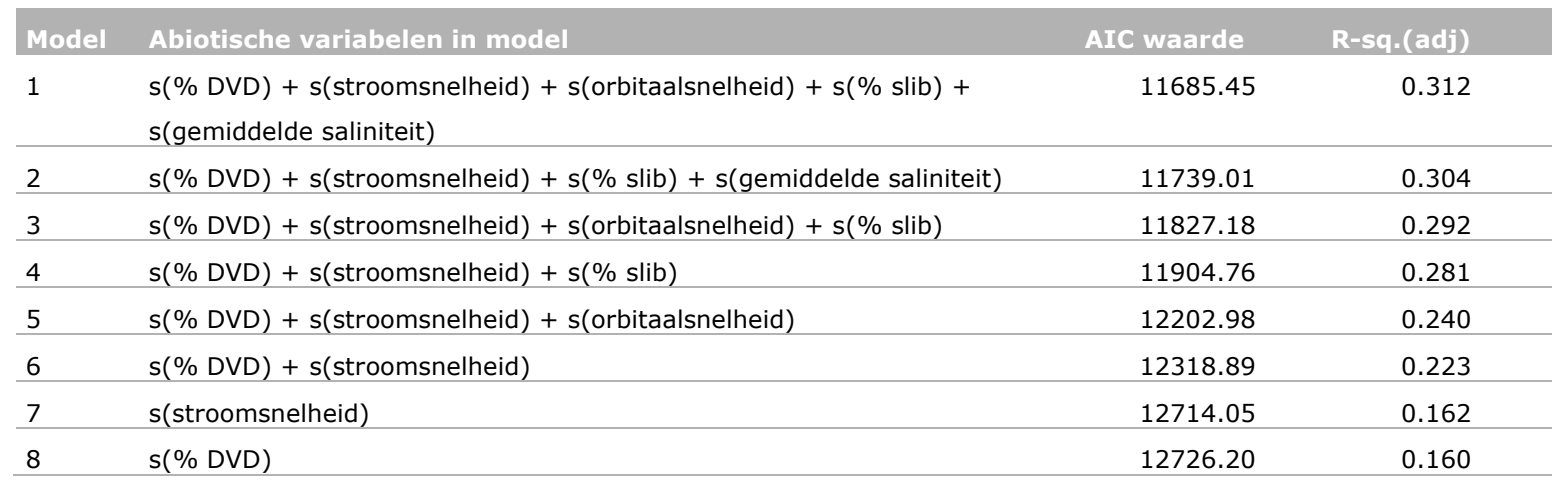
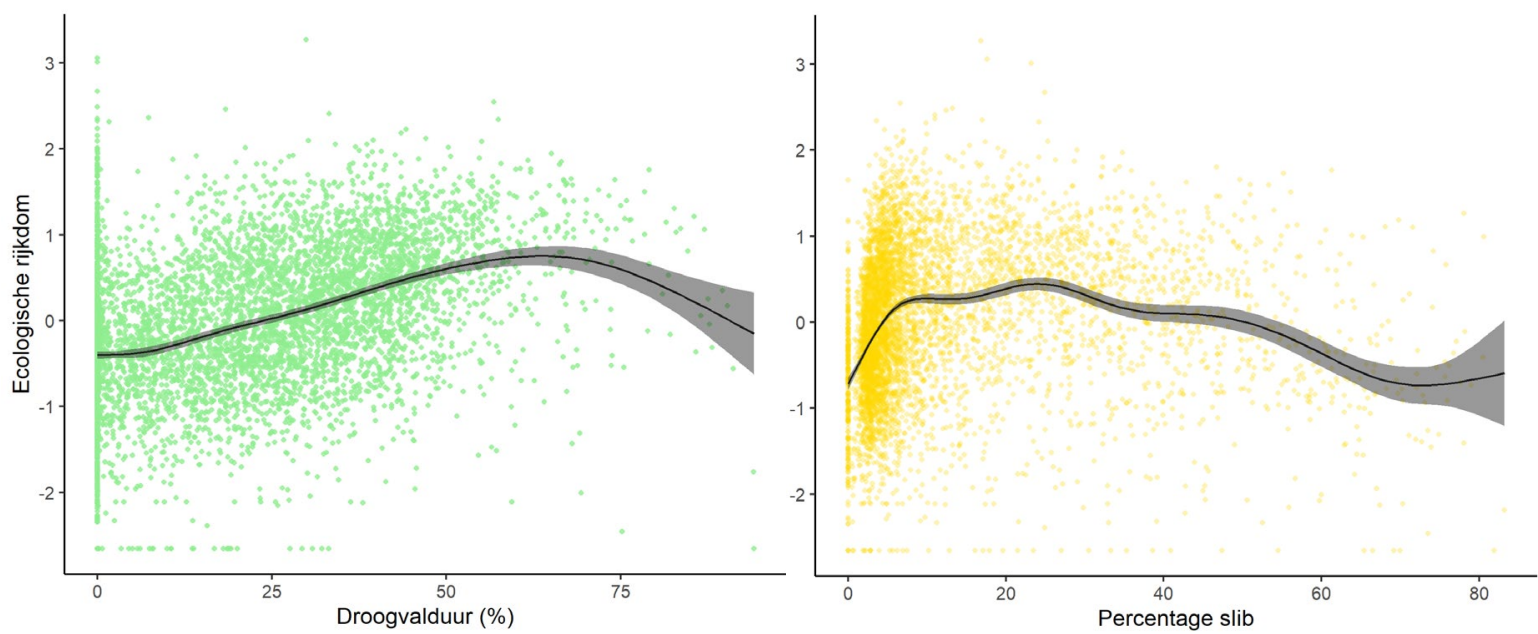

Figuur 32 Relatie tussen ecologische rijkdom van de meetpunten van het SIBES/Waddenmozaïek programma en percentage droogvalduur en slib. De trendlijn toont de voorspelde waarden met een 95\% betrouwbaarheidsinterval. 


\title{
Biotiek WOT
}

\begin{tabular}{|c|c|c|c|}
\hline \multicolumn{4}{|c|}{$\begin{array}{l}\text { Tabel } 5 \text { Uitkomsten Generalized additive models met response variabele dichtheid van } \\
\text { WOT data en verschillende abiotische factoren } \\
\text { Voor uitvoeren van de analyse zijn alle punten waar abiotische waardes misten verwijderd. Modellen } \\
\text { zijn geordend van laagste (beste model) naar hoogste (slechtste model) AIC. DVD = percentage } \\
\text { droogvalduur }\end{array}$} \\
\hline Model & Abiotische variabelen in model & AIC waarde & R-sq.(adj) \\
\hline 3 & $s(\%$ DVD $)+s($ stroomsnelheid $)+s($ orbitaalsnelheid $)+s(\%$ slib $)$ & 7257.61 & 0.135 \\
\hline 1 & $\begin{array}{l}s(\% D V D)+s(\text { stroomsnelheid })+s(\text { orbitaalsnelheid })+s(\% \text { slib })+s(\text { gemiddelde } \\
\text { saliniteit })\end{array}$ & 7258.88 & 0.138 \\
\hline 4 & $s(\%$ DVD $)+s($ stroomsnelheid $)+s(\%$ slib $)$ & 7263.10 & 0.131 \\
\hline 2 & $s(\%$ DVD $)+s($ stroomsnelheid $)+s(\%$ slib $)+s($ gemiddelde saliniteit $)$ & 7265.09 & 0.131 \\
\hline 5 & $s(\%$ DVD $)+s($ stroomsnelheid $)+s($ orbitaalsnelheid $)$ & 7313.14 & 0.107 \\
\hline 6 & $s(\%$ DVD $)+s($ stroomsnelheid $)$ & 7329.72 & 0.098 \\
\hline 8 & $s(\% \mathrm{DVD})$ & 7353.70 & 0.084 \\
\hline 7 & $\mathrm{~s}$ (stroomsnelheid) & 7456.28 & 0.028 \\
\hline
\end{tabular}

\section{Biotiek Amelander Zeegat}

\begin{abstract}
Tabel 6 Uitkomsten Generalized additive models met response variabele ecologische rijkdom van Amelander Zeegat data en stroomsnelheid en orbitaalsnelheid Voor uitvoeren van de analyse zijn alle punten waar abiotische waardes misten verwijderd. Modellen zijn geordend van laagste (beste model) naar hoogste (slechtste model) AIC.
\end{abstract}

\begin{tabular}{|c|c|c|c|}
\hline Model & Abiotische variabelen in model & AIC waarde & R-sq.(adj) \\
\hline 2 & s(orbitaalsnelheid) & 521.42 & 0.072 \\
\hline 3 & s(stroomsnelheid) & 521.74 & 0.095 \\
\hline
\end{tabular}




\section{Bijlage 2 Uitkomsten habitat mapping}

Tabel $7 \quad$ Waardes uit habitat mapping SIBES/Waddenmozaïek dataset Minimale onverklaarde variantie en grenswaarden. Analyses voor stroomsnelheid en orbitaalsnelheid zijn enkel uitgevoerd voor meetpunten die vallen in het sublitoraal. "Combinatie" is de analyse waarbij zowel stroomsnelheid als orbitaalsnelheid zijn meegenomen. De analyse voor korrelgrootte is uitgevoerd voor meetpunten met een slibgehalte van $<25 \%$. De analyse voor slibgehalte is uitgevoerd voor meetpunten met een slibgehalte tussen $0-40 \%$.

\begin{tabular}{|c|c|c|c|c|c|c|c|}
\hline Abiotische variabele & & Dichtheid & Biomassa & $\begin{array}{l}\text { Soorten- } \\
\text { rijkdom }\end{array}$ & $\begin{array}{l}\text { Ecol__ } \\
\text { rijkdom }\end{array}$ & Diversiteit & $\begin{array}{c}\text { Soort- } \\
\text { samenstelling }\end{array}$ \\
\hline Droogvalduur (\%) & Onverklaarde variantie & 0.94 & 0.99 & 0.99 & 0.97 & 0.97 & 0.98 \\
\hline \multirow[t]{2}{*}{ Sublitoraal vs lit.-laag } & Grenswaarde & 11 & 11 & 20 & 11 & 13 & 12.6 \\
\hline & Onverklaarde variantie & 0.80 & 0.98 & 0.91 & 0.88 & 0.87 & 0.95 \\
\hline \multirow[t]{2}{*}{ Lit.-laag vs lit.-midden } & Grenswaarde & 35 & 29 & 32 & 32 & 31 & 29.9 \\
\hline & Onverklaarde variantie & 0.88 & 0.99 & 0.96 & 0.94 & 0.94 & 0.97 \\
\hline Lit.-midden vs lit.-hoog & Grenswaarde & 38 & 37 & 38 & 36 & 38 & 42.5 \\
\hline Stroomsnelheid $(\mathrm{m} / \mathrm{s})$ & Onverklaarde variantie & 0.93 & 0.90 & 0.98 & 0.92 & 0.99 & 0.97 \\
\hline Zwakke vs sterke stroming & Grenswaarde & 1.01 & 1.03 & 1.04 & 1.02 & 1.17 & 0.41 \\
\hline Orbitaalsnelheid (m/s) & Onverklaarde variantie & 0.94 & 0.95 & 1.00 & 0.96 & 1.00 & 0.98 \\
\hline Zwakke vs sterke golven & Grenswaarde & 0.04 & 0.02 & 0.04 & 0.04 & 0.35 & 0.1 \\
\hline Combinatie & Onverklaarde variantie & 0.92 & 0.89 & 0.98 & 0.92 & 0.99 & 0.97 \\
\hline stroomsnelheid; & Grenswaarde & 1.01 & 1.03 & 1.04 & 1.03 & 0.35 & 0.34 \\
\hline orbitaalsnelheid & & 0.42 & 0.55 & 0.68 & 0.55 & 0.25 & 0.26 \\
\hline \multirow[t]{2}{*}{ Gemiddelde saliniteit } & Onverklaarde variantie & 0.98 & 1.00 & 1.00 & 0.99 & 0.99 & 0.97 \\
\hline & Grenswaarde & 28.5 & 19.5 & 24.5 & 31.5 & 31.5 & 29.0 \\
\hline \multirow[t]{2}{*}{ Saliniteit Eems-Dollard } & Onverklaarde variantie & 0.80 & 0.96 & 0.97 & 0.94 & 0.91 & 0.92 \\
\hline & Grenswaarde & 28.5 & 22.0 & 23.5 & 28.0 & 28.0 & 28.0 \\
\hline \multirow[t]{2}{*}{ Variatie in saliniteit } & Onverklaarde variantie & 0.97 & 0.99 & 0.99 & 0.98 & 0.99 & 0.98 \\
\hline & Grenswaarde & 73 & 11 & 10.9 & 11 & 45.2 & 49.6 \\
\hline \multirow[t]{2}{*}{ Variatie Eems-Dollard } & Onverklaarde variantie & 0.79 & 0.97 & 0.97 & 0.93 & 0.90 & 0.91 \\
\hline & Grenswaarde & 13.1 & 45.6 & 49.7 & 15.4 & 14.8 & 38.6 \\
\hline Korrelgrootte $(\mu \mathrm{m})$ & Onverklaarde variantie & 0.96 & 0.97 & 0.99 & 0.97 & 0.99 & 0.98 \\
\hline Fijn vs grof zand & Grenswaarde & 276.6 & 270.4 & 270.5 & 270.4 & 132.6 & 137.4 \\
\hline Slibgehalte (\%) & Onverklaarde variantie & 0.92 & 0.94 & 0.96 & 0.92 & 0.97 & 0.94 \\
\hline Laag vs hoog slibgehalte & Grenswaarde & 3.4 & 3.2 & 3.3 & 3.3 & 3.3 & 9.6 \\
\hline
\end{tabular}


Tabel 8

Waardes uit habitat mapping WOT dataset

Minimale onverklaarde variantie en grenswaarden. Analyses voor stroomsnelheid en orbitaalsnelheid zijn enkel uitgevoerd voor meetpunten die vallen in het sublitoraal. "Combinatie" is de analyse waarbij zowel stroomsnelheid als orbitaalsnelheid zijn meegenomen. De analyse voor korrelgrootte is uitgevoerd voor meetpunten met een slibgehalte van $<25 \%$. De analyse voor slibgehalte is uitgevoerd voor meetpunten met een slibgehalte tussen $0-40 \%$.

\begin{tabular}{|c|c|c|c|c|c|c|c|}
\hline Abiotische variabele & & Dichtheid & Biomassa & $\begin{array}{l}\text { Soorten- } \\
\text { rijkdom }\end{array}$ & $\begin{array}{l}\text { Ecol__ } \\
\text { rijkdom }\end{array}$ & Diversiteit & $\begin{array}{l}\text { Soort- } \\
\text { samenstelling }\end{array}$ \\
\hline Droogvalduur (\%) & Onverklaarde variantie & 0.96 & 0.91 & 0.81 & 0.89 & 0.94 & 0.93 \\
\hline \multirow[t]{2}{*}{ Sublitoraal vs lit.-laag } & Grenswaarde & 0.1 & 0.1 & 0.1 & 0.1 & 0.2 & 0.1 \\
\hline & Onverklaarde variantie & 0.90 & 0.94 & 0.99 & 0.93 & 0.98 & 0.96 \\
\hline \multirow[t]{2}{*}{ Lit.-laag vs lit.-midden } & Grenswaarde & 29.9 & 29.5 & 24.1 & 29.9 & 43.8 & 33.9 \\
\hline & Onverklaarde variantie & 0.96 & 0.97 & 0.96 & 0.97 & 0.97 & 0.97 \\
\hline Lit.-midden vs lit.-hoog & Grenswaarde & 29.9 & 30 & 43.8 & 29.9 & 43.8 & 37.8 \\
\hline $\begin{array}{l}\text { Stroomsnelheid }(\mathbf{m} / \mathbf{s}) \\
\text { Waddenzee }\end{array}$ & Onverklaarde variantie & 0.99 & 0.99 & 0.98 & 0.99 & 1.00 & 0.97 \\
\hline Zwakke vs sterke stroming & Grenswaarde & 0.38 & 0.68 & 0.94 & 0.32 & 1.14 & 0.46 \\
\hline \multicolumn{8}{|l|}{ Noordzee } \\
\hline Zwakke vs sterke stroming & Grenswaarde & 0.73 & 0.73 & 0.96 & 0.73 & 0.61 & 0.74 \\
\hline $\begin{array}{l}\text { Orbitaalsnelheid }(\mathbf{m} / \mathbf{s}) \\
\text { Wadden }\end{array}$ & Onverklaarde variantie & 0.99 & 0.96 & 0.96 & 0.98 & 0.98 & 0.97 \\
\hline Zwakke vs sterke golven & Grenswaarde & 0.11 & 0.11 & 0.42 & 0.11 & 0.25 & 0.11 \\
\hline \multicolumn{8}{|l|}{ Noordzee } \\
\hline Zwakke vs sterke golven & Grenswaarde & 0.23 & 0.23 & 0.4 & 0.23 & 0.23 & 0.29 \\
\hline \multicolumn{8}{|l|}{ Noordzee } \\
\hline $\begin{array}{l}\text { stroomsnelheid; } \\
\text { orbitaalsnelheid }\end{array}$ & Grenswaarde & $\begin{array}{l}0.73 \\
0.48\end{array}$ & $\begin{array}{l}0.73 \\
0.48\end{array}$ & $\begin{array}{l}0.74 \\
0.48\end{array}$ & $\begin{array}{l}0.73 \\
0.48\end{array}$ & $\begin{array}{l}0.88 \\
0.23\end{array}$ & $\begin{array}{l}0.73 \\
0.48\end{array}$ \\
\hline \multirow[t]{2}{*}{ Gemiddelde saliniteit } & Onverklaarde variantie & 0.99 & 0.98 & 0.92 & 0.97 & 0.96 & 0.98 \\
\hline & Grenswaarde & 29.2 & 29.2 & 26.7 & 29.2 & 27.7 & 27.5 \\
\hline \multirow[t]{2}{*}{ Variatie in saliniteit } & Onverklaarde variantie & 1.00 & 1.00 & 0.94 & 0.99 & 0.97 & 0.98 \\
\hline & Grenswaarde & 143 & 25 & 42 & 33 & 41 & 31 \\
\hline Korrelgrootte $(\mu \mathrm{m})$ & Onverklaarde variantie & 1.00 & 0.99 & 0.99 & 0.99 & 0.98 & 0.98 \\
\hline Fijn vs grof zand & Grenswaarde & 126 & 214 & 246 & 213 & 239 & 213 \\
\hline Slibgehalte (\%) & Onverklaarde variantie & 0.94 & 0.96 & 0.97 & 0.95 & 0.99 & 0.98 \\
\hline Laag vs hoog slibgehalte & Grenswaarde & 9.2 & 9.6 & 5.8 & 6.8 & 5.8 & 6.2 \\
\hline
\end{tabular}


Tabel 9

Waardes uit habitat mapping Amelander Zeegat dataset

Minimale onverklaarde variantie en grenswaarden. Alle meetpunten van het Amelander Zeegat liggen in het sublitoraal. De onverklaarde variantie van soortsamenstelling is berekend door uitvoeren van een RDA (multivariate analyse), de onverklaarde variantie van de andere biotische variabelen met een anova

\begin{tabular}{|c|c|c|c|c|c|c|c|}
\hline Abiotische variabele & & Dichtheid & Biomassa & $\begin{array}{l}\text { Soorten- } \\
\text { rijkdom }\end{array}$ & $\begin{array}{l}\text { Ecol__ } \\
\text { rijkdom }\end{array}$ & Diversiteit & $\begin{array}{c}\text { Soort- } \\
\text { samenstelling }\end{array}$ \\
\hline Stroomsnelheid $(\mathrm{m} / \mathrm{s})$ & Onverklaarde variantie & 0.96 & 0.86 & 0.87 & 0.92 & 0.97 & 0.89 \\
\hline Zwakke vs sterke stroming & Grenswaarde & 1.58 & 0.89 & 0.89 & 0.89 & 0.49 & 0.89 \\
\hline Orbitaalsnelheid (m/s) & Onverklaarde variantie & 0.95 & 0.93 & 0.96 & 0.95 & 0.88 & 0.96 \\
\hline Zwakke vs sterke golven & Grenswaarde & 0.43 & 0.53 & 0.23 & 0.56 & 0.53 & 0.49 \\
\hline Combinatie & Onverklaarde variantie & 0.93 & 0.76 & 0.84 & 0.82 & 0.86 & 0.84 \\
\hline stroomsnelheid; & Grenswaarde & 1.37 & 0.89 & 0.89 & 0.89 & 1.26 & 0.89 \\
\hline orbitaalsnelheid & & 0.43 & 0.53 & 0.56 & 0.56 & 0.43 & 0.56 \\
\hline
\end{tabular}




\section{Bijlage 3 Testen grenswaarden}

\begin{tabular}{|c|c|c|c|c|c|}
\hline \multicolumn{6}{|c|}{$\begin{array}{l}\text { Tabel } 10 \quad \text { Uitkomsten lineair models met response variabele ecologische rijkdom en diversiteit van } \\
\text { SIBES/Waddenmozaïek data en oude en nieuwe grenswaarden voor droogvalduur, stroomsnelheid en } \\
\text { sediment } \\
\text { Voor stroomsnelheid zijn enkel de meetpunten uit het sublitoraal meegenomen. AIC verschil is } \\
\text { berekend door AIC van het model met de nieuwe grenswaarden af te trekken van het model met de } \\
\text { ZES grenswaarden. Een verschil van }>2 \text { wordt gezien als een beter model. Groen = nieuwe } \\
\text { grenswaarden zijn beter dan de ouder, rood = oude grenswaarden zijn beter dan de nieuwe }\end{array}$} \\
\hline $\begin{array}{l}\text { Abiotische } \\
\text { variabele }\end{array}$ & Biotische variabele & Grenswaarden & AIC & AIC verschil & R-sq. (adj) \\
\hline \multirow[t]{4}{*}{ Droogvalduur } & Ecologische rijkdom & ZES.1 & 9457.761 & & 0.14 \\
\hline & & Nieuwe & 9342.938 & 114.823 & 0.17 \\
\hline & Diversiteit & ZES.1 & 4571.156 & & 0.19 \\
\hline & & Nieuwe & 4444.796 & 126.36 & 0.21 \\
\hline \multirow[t]{4}{*}{ Stroomsnelheid } & Ecologische rijkdom & ZES.1 & 3616.666 & & 0.05 \\
\hline & & Nieuwe & 3579.29 & 37.373 & 0.07 \\
\hline & Diversiteit & ZES.1 & 1631.088 & & 0.00 \\
\hline & & Nieuwe & 1633.677 & -2.589 & 0.00 \\
\hline Combinatie & Ecologische rijkdom & ZES.1 & 3617.155 & & 0.03 \\
\hline \multirow[t]{3}{*}{$\begin{array}{l}\text { stroomsnelheid } \\
\text { orbitaalsnelheid }\end{array}$} & & Nieuwe & 3562.728 & 54.427 & 0.07 \\
\hline & Diversiteit & ZES.1 & 1628.682 & & 0.00 \\
\hline & & Nieuwe & 1628.493 & 0.189 & 0.00 \\
\hline \multirow[t]{4}{*}{ Sediment } & Ecologische rijkdom & ZES.1 & 13834.94 & & 0.02 \\
\hline & & Nieuwe & 13519.82 & 315.12 & 0.08 \\
\hline & Diversiteit & ZES.1 & 7478.266 & & 0.01 \\
\hline & & Nieuwe & 7361.629 & 116.637 & 0.03 \\
\hline
\end{tabular}

Tabel 11 Uitkomsten lineair models met response variabele dichtheid en biomassa van WOT data en oude en nieuwe grenswaarden voor droogvalduur, combinatie van stroomsnelheid en orbitaalsnelheid en sediment

Voor de combinatie analyse zijn enkel de meetpunten uit de Noordzee meegenomen. AIC verschil is berekend door AIC van het model met de nieuwe grenswaarden af te trekken van het model met de ZES grenswaarden. Een verschil van $>2$ wordt gezien als een beter model. Groen = nieuwe grenswaarden zijn beter dan de ouder, rood = oude grenswaarden zijn beter dan de nieuwe

\begin{tabular}{|c|c|c|c|c|c|}
\hline Droogvalduur & Dichtheid & ZES. 1 & 7642.028 & & 0.06 \\
\hline \multirow[t]{2}{*}{ (Waddenzee) } & & Nieuwe & 7634.328 & 7.7 & 0.07 \\
\hline & Biomassa & ZES. 1 & 8546.211 & & 0.05 \\
\hline $\begin{array}{l}\text { Combinatie } \\
\text { stroomsnelheid } \\
\text { orbitaalsnelheid }\end{array}$ & Dichtheid & ZES. 1 & 1396.698 & & 0.00 \\
\hline (Noordzee) & & Nieuwe & 1376.677 & 20.02 & 0.06 \\
\hline
\end{tabular}




\begin{tabular}{llllll} 
& & & & \\
& & & & \\
Sediment & Drie groepen & 1327.141 & 36.14 & 0.12 \\
\hline & Dichtheid & ZES.1 & 7592.694 & & 0.05 \\
\hline & & Nieuwe & 7571.098 & 21.60 & 0.06 \\
\hline & Biomassa & ZES.1 & 8504.333 & & 0.03 \\
\hline & & Nieuwe & 8488.662 & 15.67 & 0.04 \\
\hline
\end{tabular}

Tabel 12 Uitkomsten lineaire models met response variabele ecologische rijkdom en diversiteit van Amelander Zeegat data en oude en nieuwe grenswaarden voor stroomsnelheid, orbitaalsnelheid en een combinatie van deze twee

AIC verschil is berekend door AIC van het model met de nieuwe grenswaarden af te trekken van het model met de ZES. 1 grenswaarden. Een verschil van $>2$ wordt gezien als een beter model. Groen = nieuwe grenswaarden zijn beter dan de ouder, rood = oude grenswaarden zijn beter dan de oude, zwart $=$ geen verschil.

\begin{tabular}{|c|c|c|c|c|c|}
\hline $\begin{array}{l}\text { Abiotische } \\
\text { variabele }\end{array}$ & Biotische variabele & Grenswaarden & AIC & AIC verschil & $R-s q \cdot(\operatorname{adj})$ \\
\hline \multirow[t]{3}{*}{ Stroomsnelheid } & Ecologische rijkdom & ZES.1 & 527.93 & & 0.03 \\
\hline & & Nieuwe & 521.84 & 6.08 & 0.06 \\
\hline & Diversiteit & ZES.1 & 253.41 & & 0.00 \\
\hline \multirow{3}{*}{ Orbitaalsnelheid } & & Nieuwe & 527.29 & 6.38 & 0.04 \\
\hline & Diversiteit & ZES.1 & 253.44 & & 0.00 \\
\hline & & Nieuwe & 237.07 & 16.37 & 0.08 \\
\hline \multirow{3}{*}{$\begin{array}{l}\text { Combinatie } \\
\text { stroomsnelheid } \\
\text { orbitaalsnelheid }\end{array}$} & & Nieuwe & 502.09 & 33.38 & 0.15 \\
\hline & Diversiteit & ZES.1 & 251.39 & & 0.01 \\
\hline & & Nieuwe & 239.28 & 12.11 & 0.07 \\
\hline
\end{tabular}

Tabel 13 Uitkomsten multivariate modellen (RDA) met response variabele soortsamenstelling van SIBES/Waddenmozaïek data en oude en nieuwe grenswaarden voor droogvalduur, stroomsnelheid en sediment

Voor stroomsnelheid zijn enkel de meetpunten uit het sublitoraal meegenomen. $R$-squared is berekend als de "constrained" variantie gedeeld door "constrained"+"unconstrained" variantie uit de RDA output. Met een anova is significantie van het model getest

\begin{tabular}{|c|c|c|c|c|c|}
\hline $\begin{array}{l}\text { Abiotische } \\
\text { variabele }\end{array}$ & Biotische variabele & Grenswaarden & $R-s q$ & F-value & $\mathbf{p}$ \\
\hline \multirow[t]{2}{*}{ Droogvalduur } & Soortsamenstelling & ZES. 1 & 0.07 & 100.44 & $0.001 * * *$ \\
\hline & & Nieuwe & 0.08 & 117.04 & $0.001 * * *$ \\
\hline Stroomsnelheid & Soortsamenstelling & ZES.1 & 0.02 & 24.34 & $0.001 * * *$ \\
\hline \multicolumn{6}{|l|}{$\begin{array}{l}\text { Stroomsnelheid } \\
\text { orbitaalsnelheid }\end{array}$} \\
\hline & & Nieuwe & 0.02 & 29.98 & $0.001 * * *$ \\
\hline Sediment & Soortsamenstelling & ZES. 1 & 0.04 & 118.83 & $0.001 * * *$ \\
\hline
\end{tabular}


Tabel 14

Uitkomsten multivariate modellen (RDA) met response variabele soortsamenstelling van

Amelander Zeegat data en oude en nieuwe grenswaarden voor stroomsnelheid, orbitaalsnelheid en de combinatie van de twee.

$R$-squared is berekend als de "constrained" variantie gedeeld door "constrained"+ "unconstrained" variantie uit de RDA output. Met een anova is significantie van het model getest

\begin{tabular}{|c|c|c|c|c|c|}
\hline $\begin{array}{l}\text { Abiotische } \\
\text { variabele }\end{array}$ & Biotische variabele & Grenswaarden & R-sq. & F-value & $\mathbf{p}$ \\
\hline \multirow[t]{2}{*}{ Stroomsnelheid } & Soortsamenstelling & ZES.1 & 0.06 & 12.97 & $0.001 * * *$ \\
\hline & & Nieuwe & 0.10 & 22.37 & $0.001 * * *$ \\
\hline Orbitaalsnelheid & Soortsamenstelling & ZES.1 & 0.02 & 3.95 & $0.009 * *$ \\
\hline $\begin{array}{l}\text { Combinatie } \\
\text { stroomsnelheid } \\
\text { orbitaalsnelheid }\end{array}$ & & Nieuwe & 0.14 & 32.69 & $0.001 * * *$ \\
\hline
\end{tabular}




\section{Bijlage 4 Aanvullende analyses grenswaarden slibgehalte}
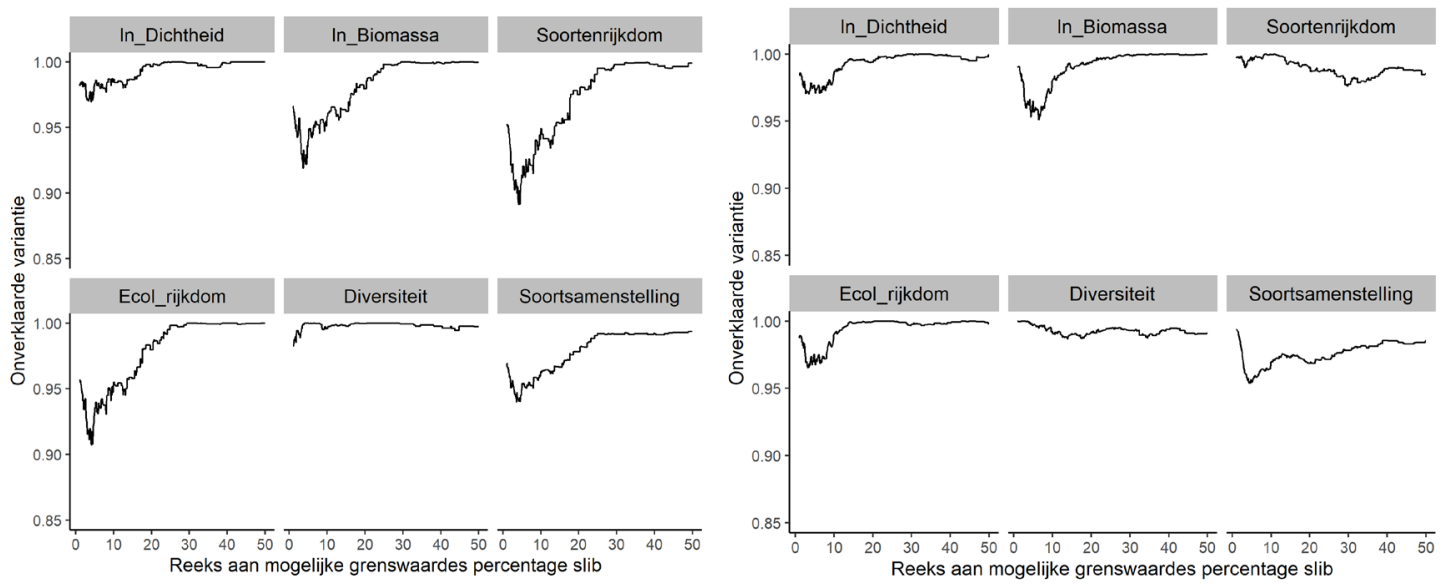

Onverklaarde variantie op de y-as met mogelijke grenswaarden voor slibgehalte sublitoraal hoogdynamisch (links) en slibgehalte sublitoraal laagdynamisch (rechts) van de

SIBES/Waddenmozaïek dataset. Het "dal" geeft een mogelijke grenswaarde aan. De onverklaarde variantie van soortsamenstelling is berekend door uitvoeren van een RDA (multivariate analyse), de onverklaarde variantie van de andere biotische variabelen met een anova.

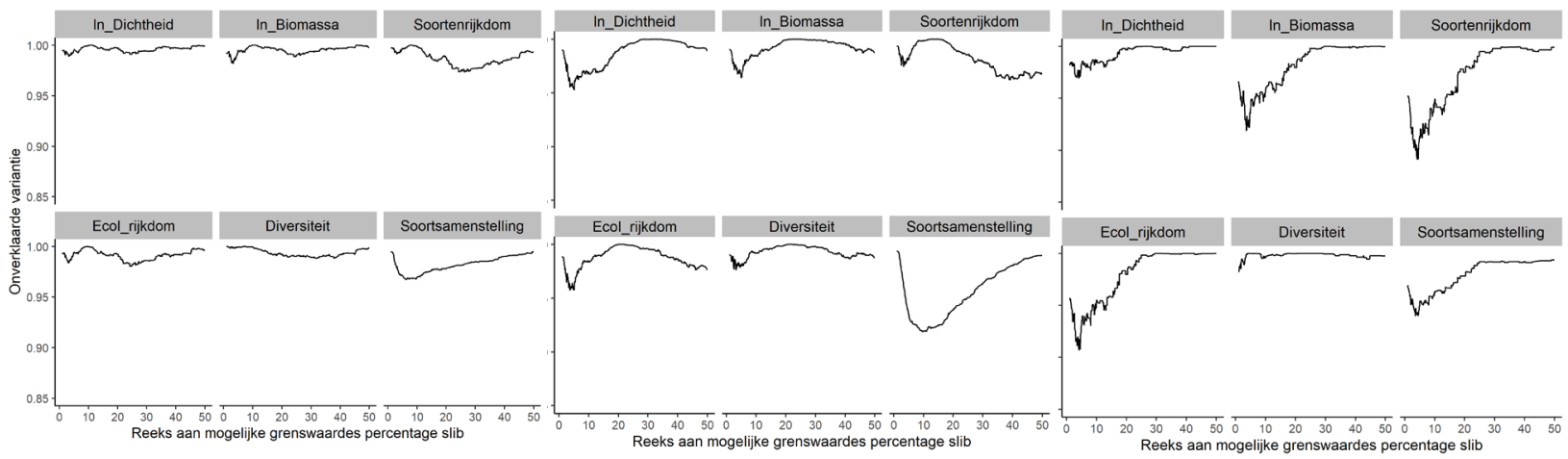

Onverklaarde variantie op de y-as met mogelijke grenswaarden voor slibgehalte litoraal-laag (links), litoraal-midden (midden) en litoraal-hoog (rechts) van de SIBES/Waddenmozaïek dataset. Het "dal" geeft een mogelijke grenswaarde aan. De onverklaarde variantie van soortsamenstelling is berekend door uitvoeren van een RDA (multivariate analyse), de onverklaarde variantie van de andere biotische variabelen met een anova. 

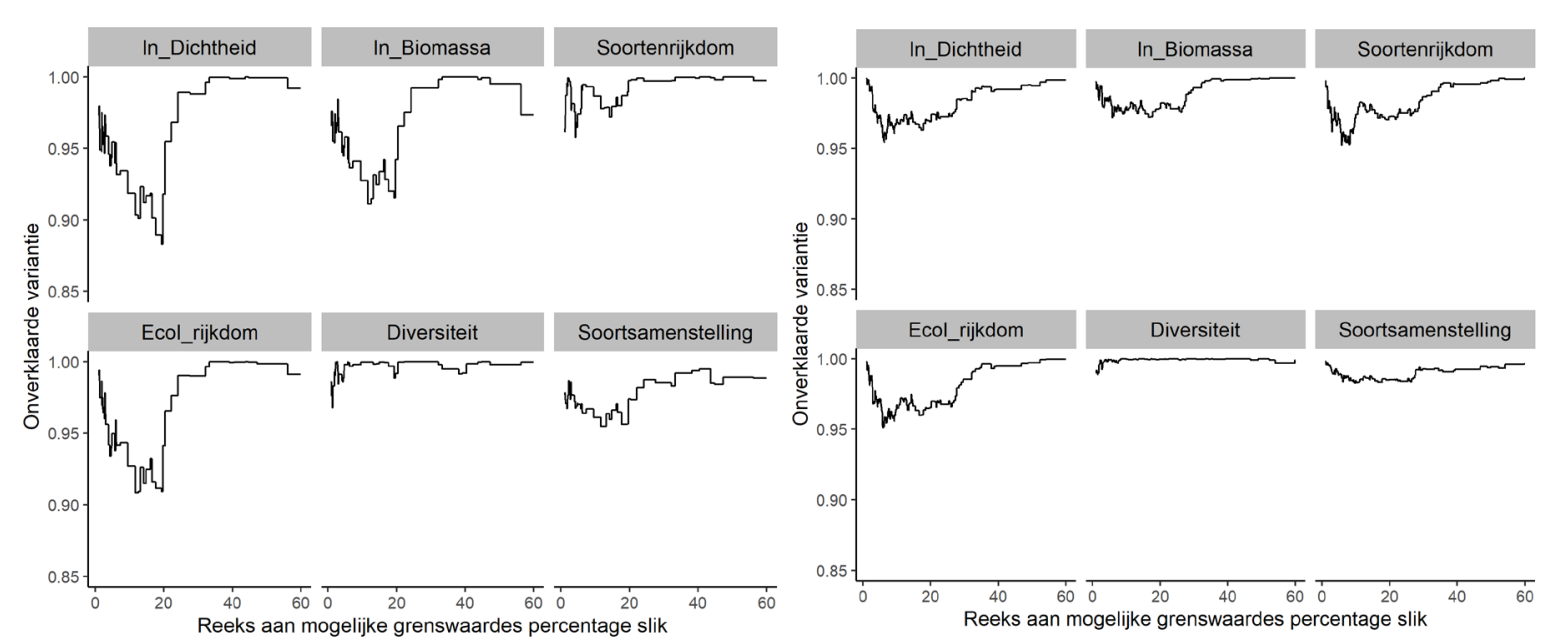

Onverklaarde variantie op de y-as met mogelijke grenswaarden voor slibgehalte sublitoraal hoogdynamisch (links) en slibgehalte sublitoraal laagdynamisch (rechts) van de WOT dataset. Het "dal" geeft een mogelijke grenswaarde aan. De onverklaarde variantie van soortsamenstelling is berekend door uitvoeren van een RDA (multivariate analyse), de onverklaarde variantie van de andere biotische variabelen met een anova.
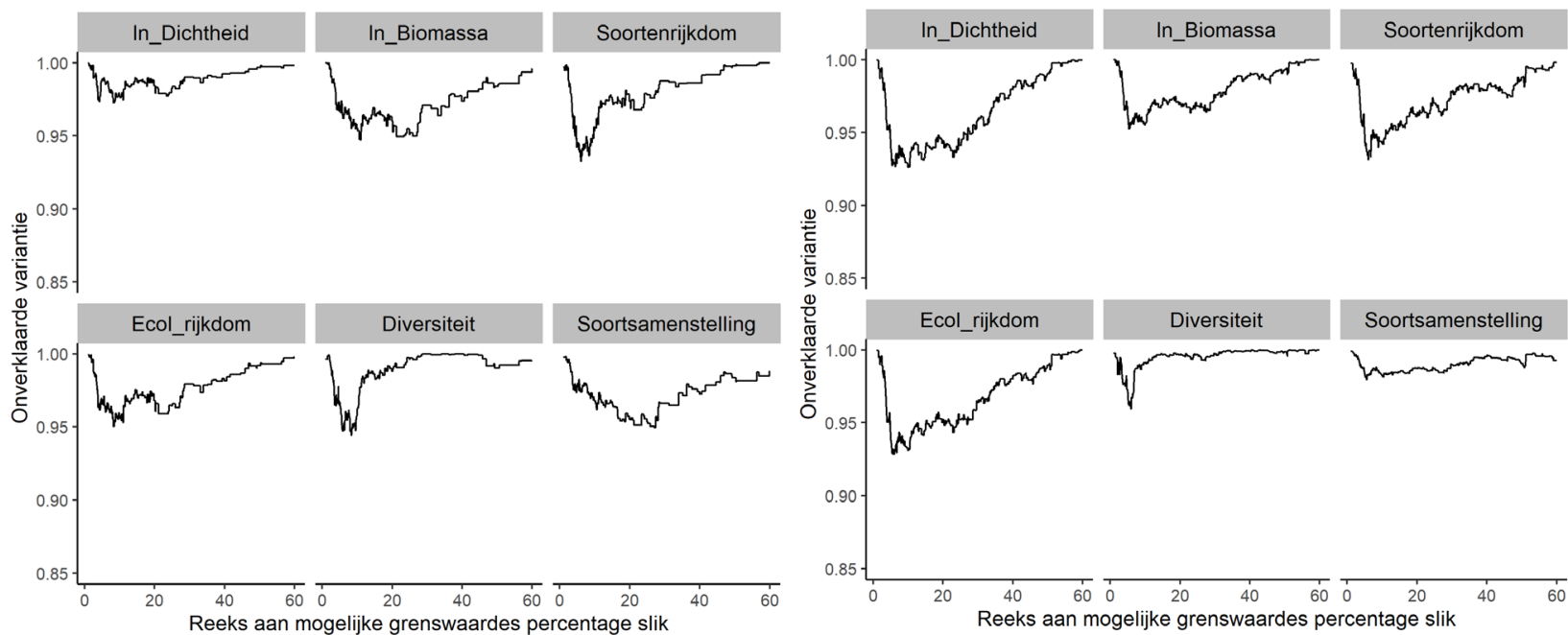

Onverklaarde variantie op de y-as met mogelijke grenswaarden voor slibgehalte litoraal-laag (links) en litoraal-midden (rechts) van de WOT dataset. Het "dal" geeft een mogelijke grenswaarde aan. De onverklaarde variantie van soortsamenstelling is berekend door uitvoeren van een RDA (multivariate analyse), de onverklaarde variantie van de andere biotische variabelen met een anova. 
Wageningen Marine Research

T: $+31(0) 317487000$

E: marine-research@wur.nl

www.wur.nl/marine-research

Bezoekers adres:

- Ankerpark 27, 1781 AG Den Helder

- Korringaweg 7, 4401 NT Yerseke

- Haringkade 1, 1976 CP IJmuiden
Wageningen Marine Research levert met kennis, onafhankelijk wetenschappelijk onderzoek en advies een wezenlijke bijdrage aan een duurzamer, zorgvuldiger beheer, gebruik en bescherming van de natuurlijke rijkdommen in zee-, kust- en zoetwatergebieden.
Wageningen Marine Research is onderdeel van Wageningen University \& Research. Wageningen University \& Research is het samenwerkingsverband tussen Wageningen University en Stichting Wageningen Research en heeft als missie: 'To explore the potential of nature to improve the quality of life' 